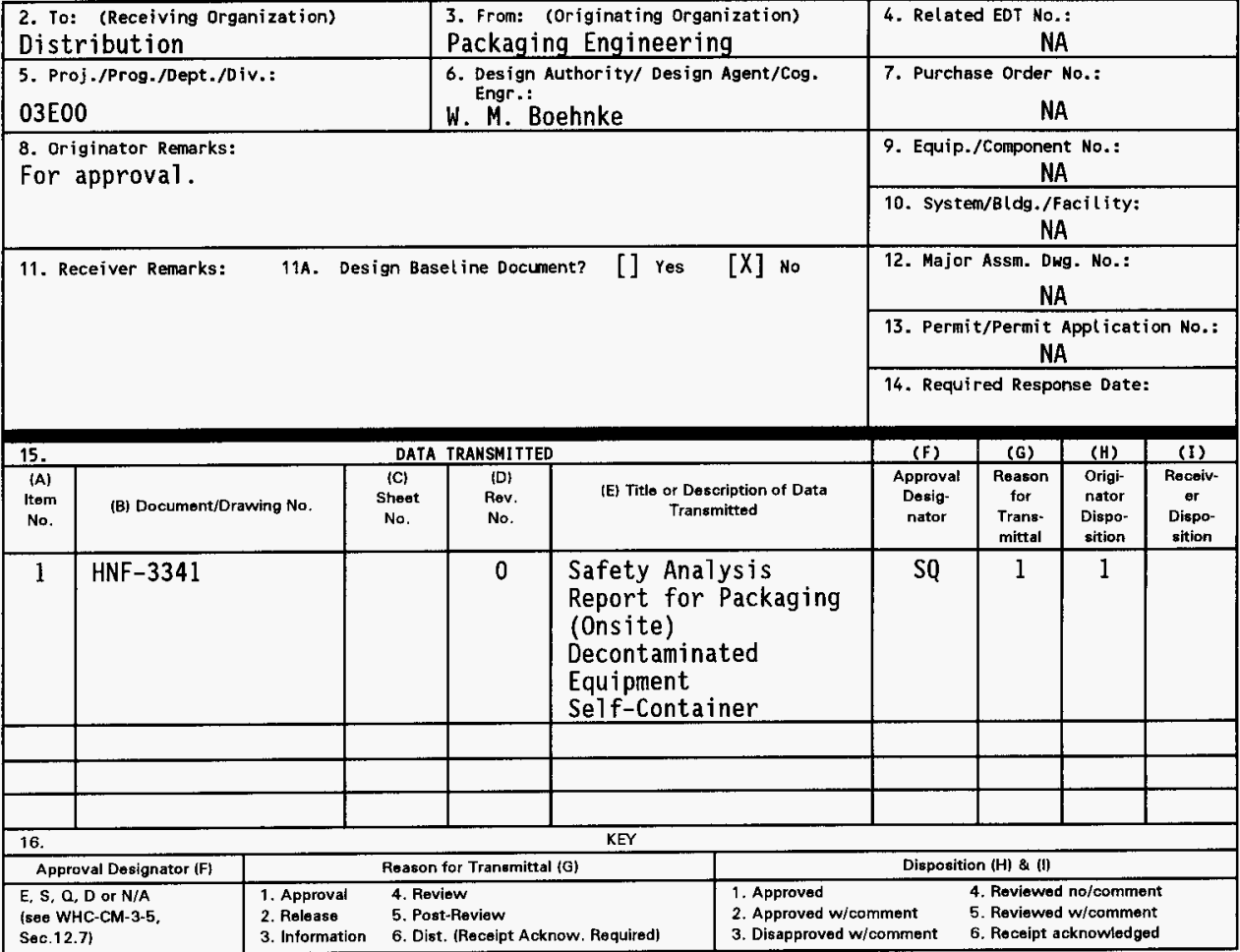

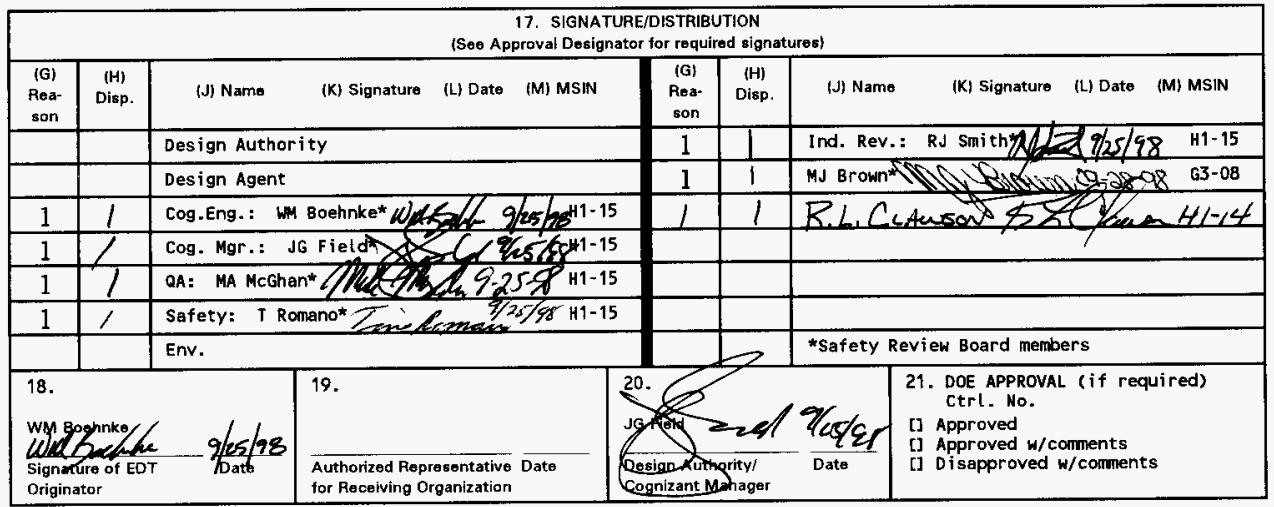

BD-7400-172-2 (05/96) GEF097 
HNF-3341, Rev. 0

\section{Safety Analysis Report for Packaging (Onsite) Decontaminated Equipment Self-Container}

W. M. Boehnke

Waste Management Federal Services, Inc., Northwest Operations, Richland, WA 99352

U.S. Department of Energy Contract DE-AC06-96RL13200

EDT/ECN: EDT 622968 UC: 513

Org Code: $03 \mathrm{E} 00$

Charge Code: B1272

Project: 772027 Crosswalk: 40-014-001

B\&R Code: EX7002000

Total Pages: 100

Key Words: Decontaminated Equipment Self-Container, self-container, SARP, onsite

Abstract: The purpose of this Safety Analysis Report for Packaging (SARP) is to demonstrate that specific decontaminated equipment can be safely used as its own self-container. As a Decontaminated Equipment Self-Container (also referred to as a self-container), no other packaging, such as a burial box, would be required to transport the equipment onsite. The self-container will consist of a piece of equipment or apparatus which has a11 readily removable interior contamination removed, all of its external openings sealed, and all external surfaces decontaminated to less than $2000 \mathrm{dpm} / 100 \mathrm{~cm}^{2}$ for gamma-emitting radionuclides and less than $220 \mathrm{dpm} / 100 \mathrm{~cm}^{2}$ for alpha-emitting radionuclides.

TRADEMARK DISCLAIMER. Reference herein to any specific comercial product, process, or service by trade name, trademark, manufacturer, or otherwise, does not necessarily constitute or imply its endorsement, recommendation, or favoring by the United States Government or any agency thereof or its contractors or subcontractors.

Printed in the United States of America. To obtain copies of this document, contact: Document Control Services, P.O. Box 950, Mailstop H6-08, Richland WA 99352, Phone (509) 372-2420; Fax (509) 376-4989.
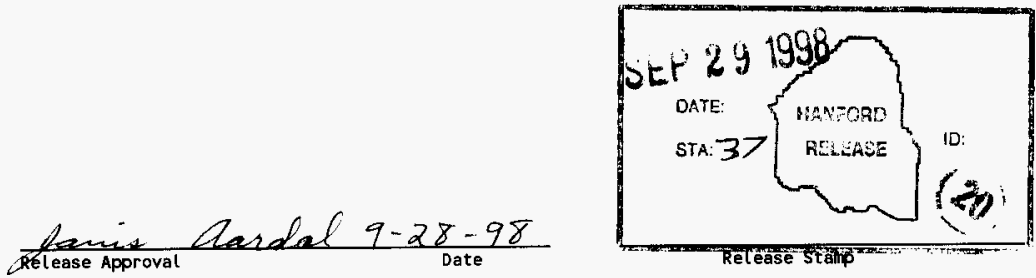

Approved for Public Release 
Rev. 0

LIST OF EFFECTIVE PAGES

\begin{tabular}{|l|c|c|}
\hline \multicolumn{1}{|c|}{ Page } & Revision & Comment \\
\hline & 0 & EDT \\
\hline & 0 & SD \\
\hline iii-viii & 0 & LOEP \\
\hline A1-1 - A1-2 & 0 & TOC \\
\hline A2-1 - A2-4 & 0 & \\
\hline A3-1 - A3-2 & 0 & \\
\hline A4-1 - A4-4 & 0 & \\
\hline A5-1 - A5-2 & 0 & \\
\hline A6-1 - A6-2 & 0 & \\
\hline A7-1 - A7-4 & 0 & \\
\hline$A 8-1-A 8-2$ & 0 & \\
\hline A9-1 - A9-2 & 0 & \\
\hline B1-1 - B1-2 & 0 & \\
\hline B2-1 - B2-2 & 0 & \\
\hline B3-1 - B3-6 & 0 & \\
\hline B4-1 - B4-16 & 0 & \\
\hline$B 5-1-B 5-2$ & 0 & \\
\hline$B 6-1-B 6-2$ & 0 & \\
\hline B7-1 - B7-10 & 0 & \\
\hline$B 8-1-B 8-12$ & 0 & \\
\hline$B 9-1-B 9-2$ & 0 & \\
\hline$B 10-1-B 10-14$ & 0 & \\
\hline
\end{tabular}


HNF-3341 Rev. 0

\section{CONTENTS}

\section{PART A: DESCRIPTION AND OPERATIONS}

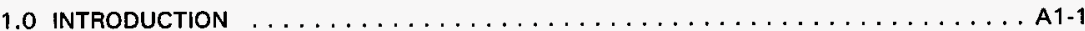

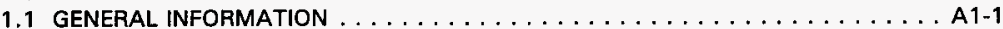

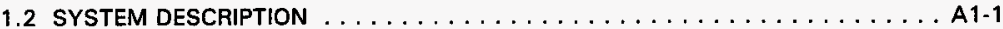

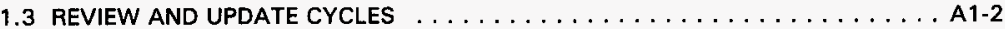

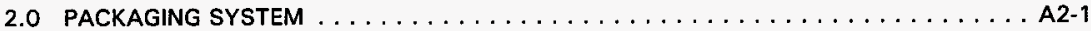

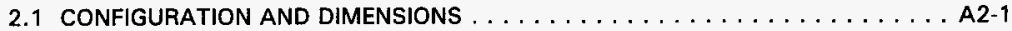

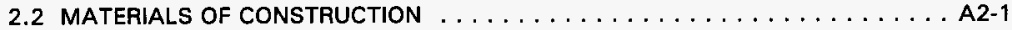

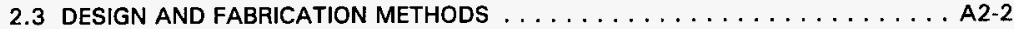

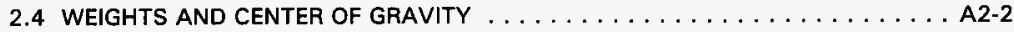

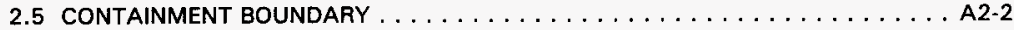

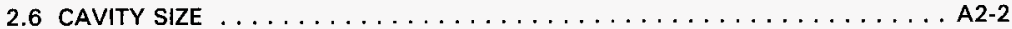

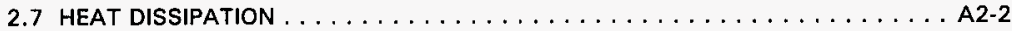

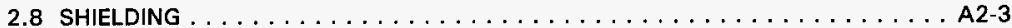

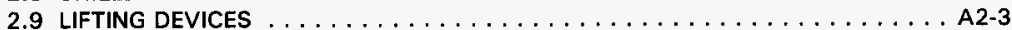

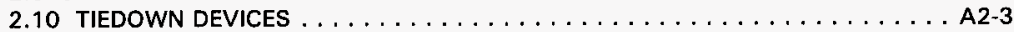

3.0 PACKAGE CONTENTS $\ldots \ldots \ldots \ldots \ldots \ldots \ldots \ldots \ldots \ldots \ldots \ldots \ldots \ldots$ A3-1

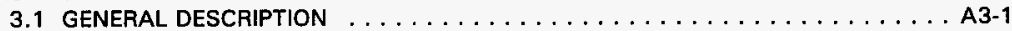

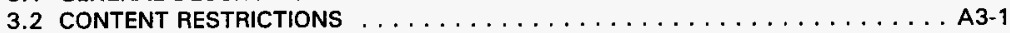

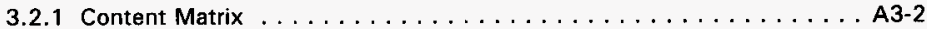

3.2.2 Radioactive Materials . . . . . . . . . . . . . . A3-2

3.2.3 Nonradioactive Materials . . . . . . . . . . . . . . A3-2

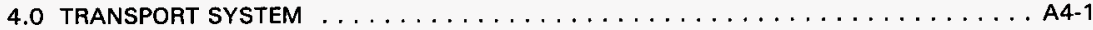

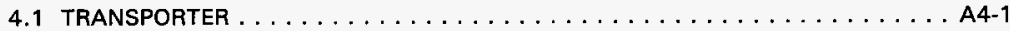

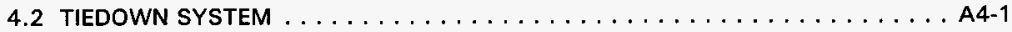

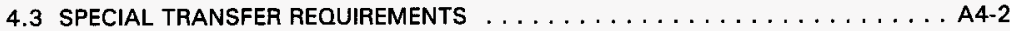

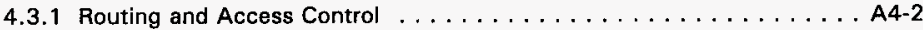

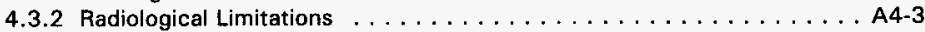

4.3.3 Time Restrictions . . . . . . . . . . . . . . . . . A4-3

4.3.4 Speed Limitations . . . . . . . . . . . . . . . . A4-3

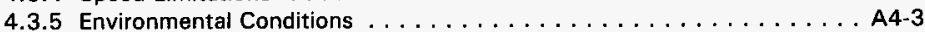

4.3.6 Frequency of Use and Mileage Limitations . . . . . . . . . . A4-3

4.3.7 Escort and Emergency Response . . . . . . . . . . . . . A4-4

5.0 ACCEPTANCE OF PACKAGING FOR USE $\ldots \ldots \ldots \ldots \ldots \ldots \ldots \ldots \ldots$

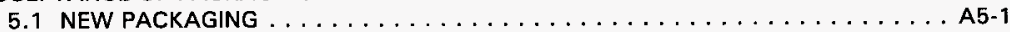

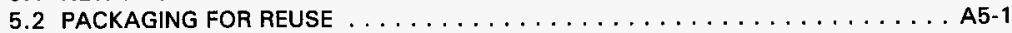

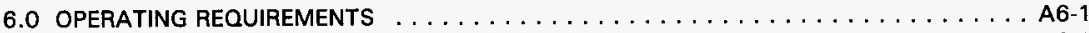

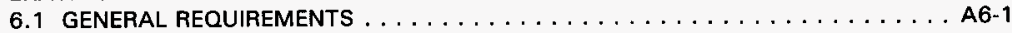

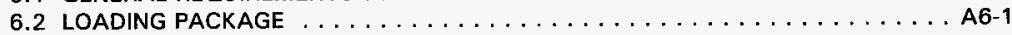

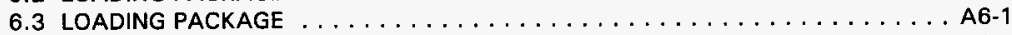

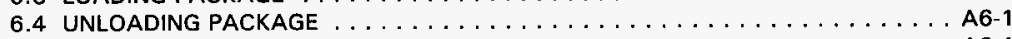

6.5 EMPTY PACKAGE (PACKAGING) $\ldots \ldots \ldots \ldots \ldots \ldots \ldots \ldots \ldots \ldots$ A6-1 
HNF-3341 Rev. 0

\section{CONTENTS (cont)}

7.0 QUALITY ASSURANCE REQUIREMENTS $\ldots \ldots \ldots \ldots \ldots \ldots \ldots \ldots \ldots \ldots \ldots$ A7-1

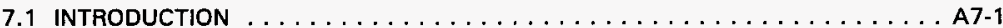

7.2 GENERAL REQUIREMENTS $\ldots \ldots \ldots \ldots \ldots \ldots \ldots \ldots \ldots \ldots \ldots$ A7-1

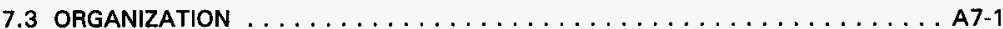

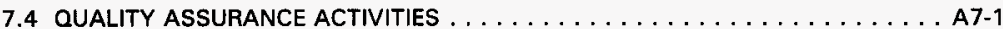

7.5 TRANSPORTATION HAZARD INDEX AND QUALITY LEVELS $\ldots \ldots \ldots \ldots \ldots \ldots$ A7-2

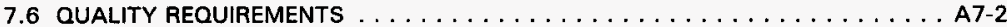

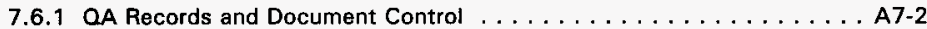

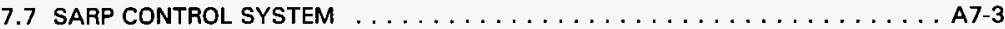

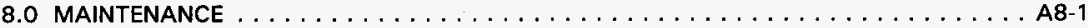

8.1 GENERAL REQUIREMENTS $\ldots \ldots \ldots \ldots \ldots \ldots \ldots \ldots \ldots \ldots \ldots \ldots \ldots$ A8-1

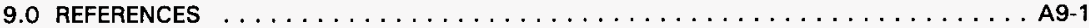

PART B: PACKAGE EVALUATION

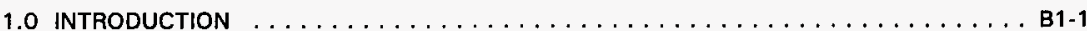

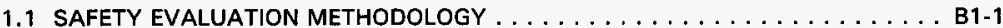

1.2 EVALUATION SUMMARY AND CONCLUSIONS $\ldots \ldots \ldots \ldots \ldots \ldots \ldots \ldots$ B1-1

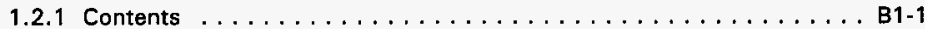

1.2.2 Radiological Risk . . . . . . . . . . . . . . . . B1-1

1.2 .3 Containment . . . . . . . . . . . . . . . . B1-1

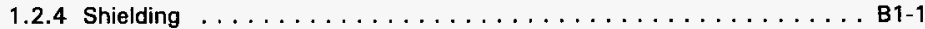

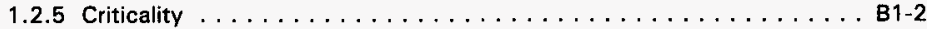

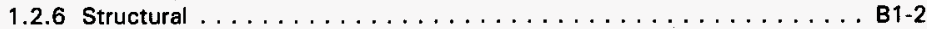

1.2.7 Thermal ........................... B1-2

1.2.8 Pressure and Gas Generation . . . . . . . . . . . . . . . B1-2

1.2 .9 Tiedown System . . . . . . . . . . . . . . . . B1-2

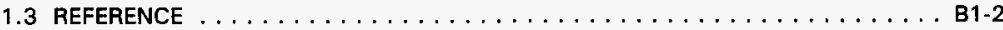

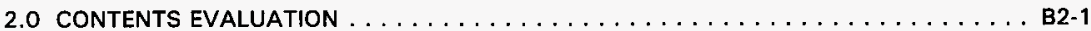

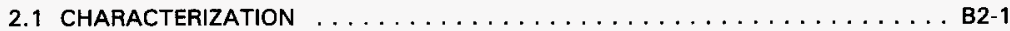

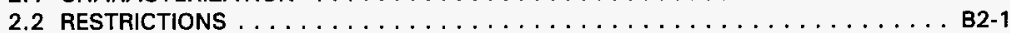

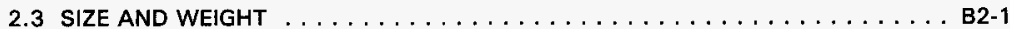

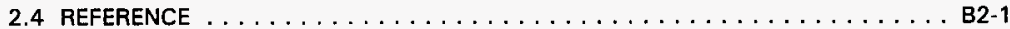

3.0 RADIOLOGICAL RISK EVALUATION $\ldots \ldots \ldots \ldots \ldots \ldots \ldots \ldots \ldots \ldots \ldots \ldots \ldots$

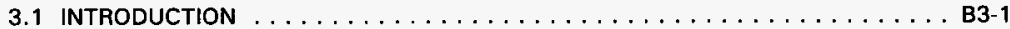

3.1.1 Summary of Resuits $\ldots \ldots \ldots \ldots \ldots \ldots \ldots \ldots \ldots \ldots \ldots$ B3-1

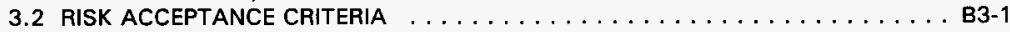

3.3 DOSE CONSEQUENCE ANALYSIS RESULTS $\ldots \ldots \ldots \ldots \ldots \ldots \ldots \ldots \ldots \ldots$

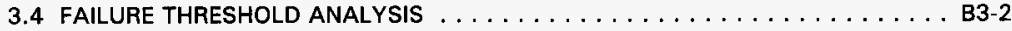

3.5 ACCIDENT FREQUENCY ASSESSMENT $\ldots \ldots \ldots \ldots \ldots \ldots \ldots \ldots \ldots \ldots$

3.5 .1 Approach . . . . . . . . . . . . . . . . . B3-3

3.5.2 Accident Release Frequency Analysis . . . . . . . . . . . . B3-4

3.6 EVALUATION AND CONCLUSION $\ldots \ldots \ldots \ldots \ldots \ldots \ldots \ldots \ldots$ B3-4

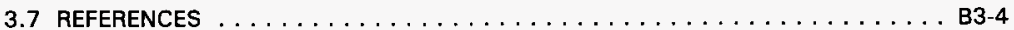


CONTENTS (cont)

4.0 CONTAINMENT EVALUATION $\ldots \ldots \ldots \ldots \ldots \ldots \ldots \ldots \ldots \ldots \ldots \ldots \ldots \ldots$ B4-1

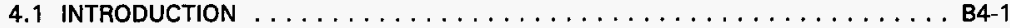

4.2 CONTAINMENT SOURCE SPECIFICATION $\ldots \ldots \ldots \ldots \ldots \ldots \ldots \ldots \ldots$ B4-1

4.3 NORMAL TRANSFER CONDITIONS $\ldots \ldots \ldots \ldots \ldots \ldots \ldots \ldots \ldots \ldots \ldots$ B4-1

4.3.1 Conditions To Be Evaluated . . . . . . . . . . . . . . . B4-1

4.3.2 Containment Acceptance Criteria . . . . . . . . . . . . . . . B4-1

4.3.3 Summary of Results . . . . . . . . . . . . . . . . . . . B4-1

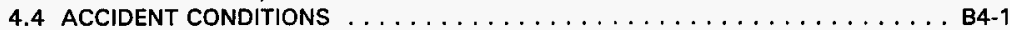

4.4.1 Conditions To Be Evaluated ... . . . . . . . . . . . . B4-1

4.4.2 Containment Acceptance Criteria . . . . . . . . . . . . . . . . B4-1

4.5 ACCIDENT CONTAINMENT EVALUATION AND SUMMARY $\ldots \ldots \ldots \ldots \ldots \ldots$ B4-1

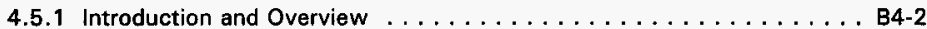

4.5.2 Dose Consequence Analysis Methodology . . . . . . . . . . . . . . B4-2

4.5.3 Source Term . . . . . . . . . . . . . . . . . . . . . . . . B4-3

4.5.4 External Dose Due to Photon (Gamma) Exposure . . . . . . . . . . . . B4-4

4.5.5 External Dose Due to Beta Particle Emitters . . . . . . . . . . . . . B4-4

4.5.6 Inhalation and Ingestion Dose . . . . . . . . . . . . B4-5

4.5.7 Dose Due to $\beta$-Particle Emitter Skin Contamination . . . . . . . . . . . B4-8

4.5.8 Submersion Dose Due to Gaseous Vapor . . . . . . . . . . . . . B4-8

4.5.9 Special Considerations . . . . . . . . . . . . . . . B4-8

4.5.10 References . . . . . . . . . . . . . . . . . . B B4-9

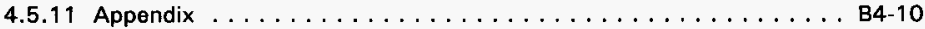

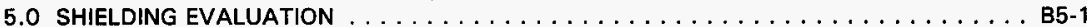

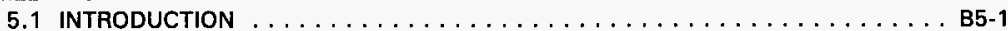

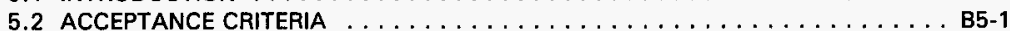

5.3 SHIELDING SUMMARY $\ldots \ldots \ldots \ldots \ldots \ldots \ldots \ldots \ldots \ldots \ldots \ldots$

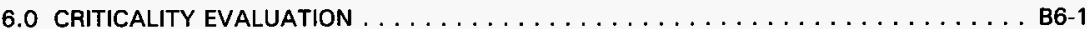

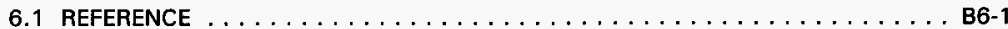

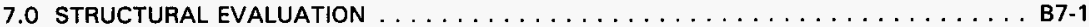

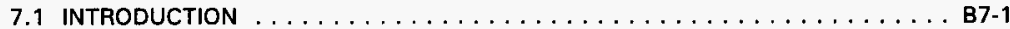

7.2 STRUCTURAL EVALUATION OF PACKAGE $\ldots \ldots \ldots \ldots \ldots \ldots \ldots \ldots \ldots$ B7-1

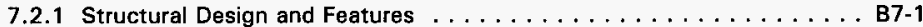

7.2.2 Mechanical Properties of Materials . . . . . . . . . . . B 7.1

7.2.3 Chemical and Galvanic Reactions . . . . . . . . . . . . . B7-1

7.2.4 Size of Package and Cavity . . . . . . . . . . . . . . . B7-2

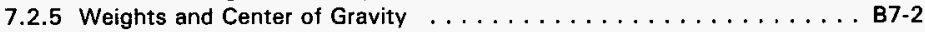

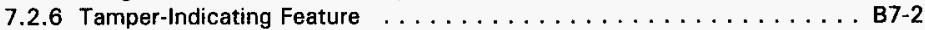

7.2 .7 Positive Closure . . . . . . . . . . . . . . . . . . . . B7-2

7.2.8 Lifting and Tiedown Devices . . . . . . . . . . . . . . . B7-2

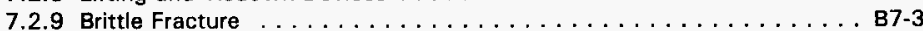

7.3 NORMAL TRANSFER CONDITIONS $\ldots \ldots \ldots \ldots \ldots \ldots \ldots \ldots \ldots \ldots$

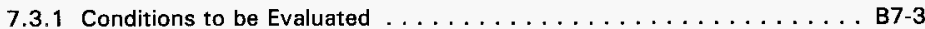

7.3.2 Acceptance Criteria . . . . . . . . . . . . . . . . . . . B7-4

7.3.3 Environmental Heating . . . . . . . . . . . . . . . B7-4

7.3.4 Maximum Thermal and Pressure Stresses . . . . . . . . . . . . B7-4

7.3 .5 Inertial Loading . . . . . . . . . . . . . . . . . B7-5

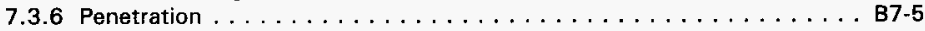

7.3.7 Structural Evaluation Conclusions $\ldots \ldots \ldots \ldots \ldots \ldots \ldots \ldots$ B7-5 
HNF-3341 Rev. 0

\section{CONTENTS (cont)}

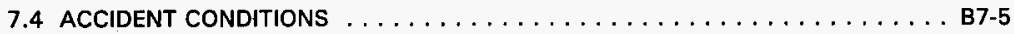

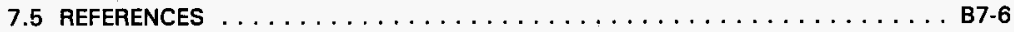

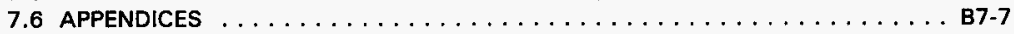

7.6.1 Penetration Evaluation $\ldots \ldots \ldots \ldots \ldots \ldots \ldots \ldots \ldots \ldots \ldots \ldots$ B7-7

8.0 THERMAL EVALUATION $\ldots \ldots \ldots \ldots \ldots \ldots \ldots \ldots \ldots \ldots \ldots \ldots \ldots \ldots \ldots \ldots$ B8-1

8.1 INTRODUCTION $\ldots \ldots \ldots \ldots \ldots \ldots \ldots \ldots \ldots \ldots \ldots \ldots \ldots$ B8-1

8.2 THERMAL EVALUATION OF PACKAGE $\ldots \ldots \ldots \ldots \ldots \ldots \ldots \ldots$ B8-1

8.2.1 Package Description . . . . . . . . . . . . . . . . B8-1

8.3 NORMAL TRANSPORT CONDITIONS THERMAL EVALUATION $\ldots \ldots \ldots \ldots$ B8-1

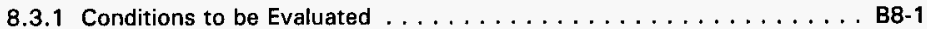

8.3.2 Acceptance Criteria . . . . . . . . . . . . . . . . B8-2

8.3.3 Thermal Evaluation and Conclusions . . . . . . . . . . . . B8-2

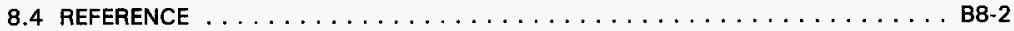

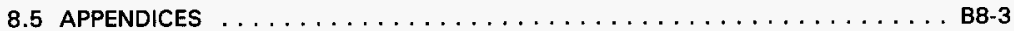

8.5.1 Cylindrical Self-Container Thermal Evaluation $\ldots \ldots \ldots \ldots \ldots \ldots$ B8-3

8.5.2 Cuboid Self-Container Thermal Evaluation . . . . . . . . . . B8-7

9.0 PRESSURE AND GAS generation EVALUATION $\ldots \ldots \ldots \ldots \ldots \ldots \ldots \ldots \ldots \ldots$ B9-1

10.0 PACKAgE TIEDOWN SYSTEM EVALUATION $\ldots \ldots \ldots \ldots \ldots \ldots \ldots \ldots \ldots \ldots \ldots$ B10-1

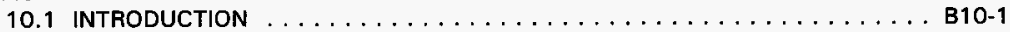

10.2 SYSTEM DESIGN . . . . . . . . . . . . . . . . . . B10-1

10.3 ATTACHMENTS, RATINGS AND REQUIREMENTS . . . . . . . . B10-2

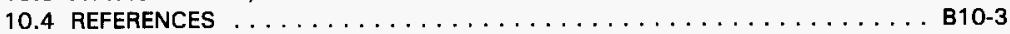

10.5 APPENDIX: TIEDOWN REQUIREMENTS EVALUATION $\ldots \ldots \ldots \ldots \ldots \ldots$ B $10-4$ 
HNF-3341 Rev. 0

\section{LIST OF FIGURES}

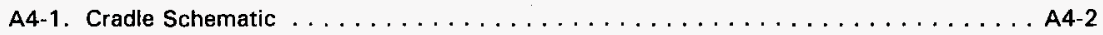

B10-1. Cradle Schematic $\ldots \ldots \ldots \ldots \ldots \ldots \ldots \ldots \ldots \ldots \ldots \ldots \ldots \ldots \ldots$ B10-2

\section{LIST OF TABLES}

A2-1. Minimum Thickness of Materials $\ldots \ldots \ldots \ldots \ldots \ldots \ldots \ldots \ldots \ldots \ldots \ldots$ A2-2

A4-1. Removable External Radioactive Contamination--Wipe Limits $\ldots \ldots \ldots \ldots \ldots \ldots$ A4-3

A7-1. Functional Responsibility Matrix $\ldots \ldots \ldots \ldots \ldots \ldots \ldots \ldots \ldots \ldots \ldots \ldots \ldots$

A7-2. Retention and Location Matrix $\ldots \ldots \ldots \ldots \ldots \ldots \ldots \ldots \ldots \ldots \ldots \ldots$

B3-1. Risk Acceptance Criteria Limits (Effective Dose Equivalent) $\ldots \ldots \ldots \ldots \ldots \ldots$. . B3-2

B3-2. Summary of Dose Consequence Results $\ldots \ldots \ldots \ldots \ldots \ldots \ldots \ldots \ldots \ldots \ldots$

B4-1. Summary of Doses From Each Pathway for Fire Scenario . . . . . . . . . . . B4-2

B4-2. B-Particle Dose Rate for Beta Emitters Contributing $>0.01 \%$ to the Total Dose . . . B4-5

B4-3. Whole Body Dose, Sv EDE (rem EDE), for the Hanford Site Worker and the Public . . . B4-7

B7-1. Solar Heat Loads $\ldots \ldots \ldots \ldots \ldots \ldots \ldots \ldots \ldots \ldots \ldots \ldots \ldots \ldots$

B7-2. Minimum Thickness of Materials $\ldots \ldots \ldots \ldots \ldots \ldots \ldots \ldots \ldots \ldots \ldots$

B8-1. Solar Heat Loads $\ldots \ldots \ldots \ldots \ldots \ldots \ldots \ldots \ldots \ldots \ldots \ldots \ldots \ldots \ldots$ 


\section{LIST OF TERMS}

$\begin{array}{ll}\text { ALARA } & \text { as low as reasonably achievable } \\ \text { ASTM } & \text { American Society of Testing and Materials } \\ \text { Bq } & \text { bequerel } \\ \text { CCMTA } & \text { Canadian Council of Motor Transportation Administration } \\ \text { Ci } & \text { curie } \\ \text { cm } & \text { centimeter } \\ \text { DOE } & \text { U.S. Department of Energy } \\ \text { dpm/cm } & \text { disintegrations per minute per square centimeter } \\ \text { DOT } & \text { U.S. Department of Transportation } \\ \text { ECN } & \text { engineering change notice } \\ \text { EDE } & \text { effective dose equivalent } \\ \text { g } & \text { gram } \\ \text { FDH } & \text { Fluor Daniel Hanford, Inc. } \\ \text { ft } & \text { foot } \\ \text { IAEA } & \text { International Atomic Energy Agency } \\ \text { in. } & \text { inch } \\ \text { kg } & \text { kilogram } \\ \text { lb } & \text { pound } \\ \text { m } & \text { meter } \\ \text { mrem/h } & \text { millirem per hour } \\ \text { mSv/h } & \text { millisievert per hour } \\ \text { NTC } & \text { normal transport conditions } \\ \text { PHMC } & \text { Project Hanford Management Contract } \\ \text { QA } & \text { Quality Assurance } \\ \text { QL } & \text { quality level } \\ \text { RL } & \text { U.S. Department of Energy, Richland Operations Office } \\ \text { SARP } & \text { Safety Analysis Report for Packaging } \\ \text { Sv } & \text { sievert } \\ \text { TEDE } & \text { total committed effective dose equivalent } \\ \text { THI } & \text { Transportation Hazard Index } \\ \text { WMNW } & \text { Waste Management Federal Services, Inc., Northwest operations } \\ & \end{array}$


HNF-3341 Rev. 0

\section{SAFETY ANALYSIS REPORT FOR PACKAGING (ONSITE) DECONTAMINATED EQUIPMENT SELF-CONTAINER}

\section{PART A: DESCRIPTION AND OPERATIONS}

\subsection{INTRODUCTION}

\subsection{GENERAL INFORMATION}

The purpose of this Safety Analysis Report for Packaging (SARP) is to demonstrate that specific decontaminated equipment can be safely used as its own self-container. As a Decontaminated Equipment Self-Container (herein referred to as the self-container), no other packaging, such as a burial box, would be required to transport the equipment onsite. The self-container will consist of a piece of equipment or apparatus which has all readily removable interior contamination removed, all of its external openings sealed, and all external surfaces decontaminated or fixed to less than $2200 \mathrm{dpm} / 100 \mathrm{~cm}^{2}$ for gamma-emitting radionuclides and less than $220 \mathrm{dpm} / 100 \mathrm{~cm}^{2}$ for alpha-emitting radionuclides. Typical self-containers would be glove boxes, pressure vessels, tanks, or heat exchangers.

This SARP allows judgment by the shipper to ensure self-containers are of sufficient structural integrity to meet the requirements of the SARP. This is possible by limiting the quantity and form of radioactive material authorized for onsite transportation.

This SARP verifies that self-containers, used as specified herein, meet the requirements of HNF-PRO-154, Responsibilities and Procedures for All Hazardous Material Shipments, for Type B, fissile exempt quantities of radioactive material.

\subsection{SYSTEM DESCRIPTION}

A self-container shall be capable of satisfying the following conditions:

1. It is capable of providing containment and shielding of internal radioactive material.

2. All readily removable waste material in the interior of the self-container is removed.

3. Radioactive material remaining within the self-container is fixed to the extent feasible with an approved fixant and all external openings are sealed.

4. Exterior of the self-container meets surface contamination limits for smearable contamination of less than $2200 \mathrm{dpm} / 100 \mathrm{~cm}^{2}$ for beta-gamma emitting radionuclides and less than $220 \mathrm{dpm} / 100 \mathrm{~cm}^{2}$ for alpha-emitting radionuclides.

5. The radiation dose on the external surface of the self-container is less than $10 \mathrm{mSv} / \mathrm{h}(1,000 \mathrm{mrem} / \mathrm{h})$. The radiation dose at $2 \mathrm{~m}$ from any point on the self-container shall not exceed $0.1 \mathrm{mSv} / \mathrm{h}(10 \mathrm{mrem} / \mathrm{h})$. At the driver location, the dose rate shall not exceed $0.02 \mathrm{mSv} / \mathrm{h}(2 \mathrm{mrem} / \mathrm{h})$ if the driver is not a trained radiological worker, or $0.05 \mathrm{mSv} / \mathrm{h}(5 \mathrm{mrem} / \mathrm{h})$ if the driver is a radiological worker. 
HNF-3341 Rev. 0

6. The amount of radioactive material shipped may be up to $100 \mathrm{~A}_{2} \mathrm{~s}$ (Type B). Fissile excepted materials are permitted.

7. No free liquids are permitted.

8. No radioactive material shall be added to the self-container.

9. For shipment, the self-containers are transported by truck.

\subsection{REVIEW AND UPDATE CYCLES}

This SARP is subject to periodic reviews and updates. The reviews shall be performed every five years to ensure that all SARP evaluations and other included information meet new or revised regulatory and/or company requirements. The first complete review and update of this onsite SARP will be approximately September 2003. Review shall be through the formal process per Part A, Section 7.5. 


\subsection{PACKAGING SYSTEM}

\subsection{CONFIGURATION AND DIMENSIONS}

Self-containers will be of various shapes and sizes enveloped by a $12 \mathrm{~m}(40 \mathrm{ft})$ long by $2.5 \mathrm{~m}(8 \mathrm{ft}$ ) wide by $3 \mathrm{~m}$ (10 ft) high cuboid and a $12 \mathrm{~m}(40 \mathrm{ft})$ long by $2.5 \mathrm{~m}(8 \mathrm{ft})$ diameter cylinder. The package weight for shipment under this SARP is $22,680 \mathrm{~kg}(50,000 \mathrm{lb})$. Package parameters specified above are for packages which can be transported by standard conveyances. Oversized packages having geometries and/or weights which exceed the above specified parameters may be transported under this SARP under the following conditions:

1. The package meets all requirement of Part B, Section 7.2.

2. The tiedown system conforms to all requirements specified in Part B, Section 10.2 for oversized packages.

3. The conveyance to be used shall have sufficient distributed and concentrated load capacities to transport the package.

4. An authorized representative of Waste Management Federal Services, Inc., Northwest Operations (WMNW) Transportation Logistics shall approve the tiedown and blocking configuration.

\subsection{MATERIALS OF CONSTRUCTION}

Self-containers must have sufficient structural integrity to support their own weight and sustain the normal transport conditions (NTC) loadings without fracturing, rupturing, fragmenting or releasing of material. They may be constructed of metals, plastics, concrete, or wood and may have been fabricated by welding, gluing, bolting, nailing, forming or strapping. Self-containers should not be affected by temperature extremes or moisture. They shall not produce galvanic or chemical reactions with other packaging or content material.

The materials of construction for self-container packages can vary from stainless steel for vessels and aluminum for roll-out platform ladders to concrete slabs and plastic vessels. As a consequence, a wide array of materials are acceptable. Acceptable materials of outer construction for self-container packages are any metal, concrete (either reinforced or unreinforced), plastic, wood or composite material with sufficient strength to maintain structural integrity under NTC.

The required exterior material thickness to prevent penetration of self-container packages are determined in Part B, Section 7.6 and shown in Table A2-1. Consequently, all exterior surface components of the self-container shall have the required minimum thickness for the exterior surface material of construction, or any vulnerable area will be protected by a protective shell, which satisfies the minimum thickness requirement. 
Table A2-1. Minimum Thickness of Materials.

\begin{tabular}{|l|c|}
\hline \multicolumn{1}{|c|}{ Material } & $\begin{array}{c}\text { Minimum thickness } \\
\text { cm (in.) }\end{array}$ \\
\hline Steel & $0.328(0.129)$ \\
\hline Lead & $0.767(0.302)$ \\
\hline Aluminum & $0.394(0.155)$ \\
\hline Copper & $0.422(0.166)$ \\
\hline Concrete & $0.5(0.2)$ \\
\hline Wood & $0.8(0.3)$ \\
\hline
\end{tabular}

\subsection{DESIGN AND FABRICATION METHODS}

Packages transported under this SARP vary in size, shape, weight, and materials of construction. The self-container must be constructed of materials whose strength is not impaired when thoroughly wet with water.

\subsection{WEIGHTS AND CENTER OF GRAVITY}

The package weight for shipment under this SARP is $22,680 \mathrm{~kg}(50,000 \mathrm{lb}\}$. The center of gravity is conservatively assumed to be $\%$ the distance from the base of the package.

\subsection{CONTAINMENT BOUNDARY}

The self-container is not hermetically sealed. Content retention is accomplished by closing openings in a manner to retain contents during routine transport as follows:

1. Small round openings or small pipes are capped with tubing or pipe fittings.

2. All other openings are closed with a piece of metal either continuously welded or bolted over the openings. The resulting closure shall meet the minimum thickness requirements of Table A2-1.

\subsection{CAVITY SIZE}

The self-container may contain various cavities and void spaces. Since the self-container package itself is the package and contents, any cavities are coincidental. No additional waste will be added to the self-container.

\subsection{HEAT DISSIPATION}

There is no significant heat load. Heat is passively dissipated. 


\subsection{SHIELDING}

Shielding, if any, is provided by the self-container.

\subsection{LIFTING DEVICES}

Lifting is performed in accordance with the Hanford Site Hoisting and Rigging Manual (RL 1993 ) requirements. Whenever lifting points with known and marked ratings are provided on the unit, they may be used for lifting and handling of the package. If no lifting points with known ratings are provided, the package will be lifted and handled with slings and shackles in accordance with the Hanford Site Hoisting and Rigging Manual requirements. Components or devices on the package will not be used as a tiedown attachment or point unless it is clearly defined as such on the package or has been demonstrated to sustain a load of three times the weight of the package in the direction of loading without yielding the material.

\subsection{TIEDOWN DEVICES}

The self-container will typically not incorporate integral tiedown devices. See Part B, Section 10.0 for the tiedown analysis. 
HNF-3341 Rev. 0

This page intentionally left blank.

A2-4 
HNF-3341 Rev. 0

\subsection{PACKAGE CONTENTS}

\subsection{GENERAL DESCRIPTION}

The self-container is equipment to be transported that contains residual contamination on interior surfaces following decontamination, if necessary.

It is expected that a variety of decontaminated equipment will qualify as self-containers for transportation on the Hanford Site. Therefore, it is not possible to specify a source term based on a specific set of radionuclides with given relative residual concentrations. However, experience has shown that the radionuclides that occur with greatest activity are ${ }^{137} \mathrm{Cs}$ and ${ }^{90} \mathrm{Sr}$ and associated progeny ${ }^{137 \mathrm{~m}} \mathrm{Ba}$ and ${ }^{90} \mathrm{Y}$, respectively. Examples of decontaminated equipment transported on the Hanford Site are the General Purpose Burial Box, the Multipurpose Transfer Box, and the single shell Liquid Waste Tank Car.

The authorized source term is Type $B$, fissile excepted, and less than $100 A_{2}$ values as defined in 49 CFR 173. If more than one radionuclide is present in the contaminated material, the sum of the $A_{2}$ fractions is used to calculate the total number of $A_{2} s$.

Exterior surfaces of the self-container will be decontaminated or fixed with approved fixant, as necessary to removable contamination values less than $2200 \mathrm{dpm} / 100 \mathrm{~cm}^{2}$ for beta-gamma emitting radionuclides and less than $220 \mathrm{dpm} / \mathrm{cm}^{2}$ for alpha emitting radionuclides

(49 CFR 173.443).

\subsection{CONTENT RESTRICTIONS}

The self-container contents shall meet the following requirements:

1. The self-container shall not contain hydrogen-gas generating materials, or materials such as volatile organic compounds that can produce gases and undue pressure within the container.

2. The interior of all equipment or apparatus shall have readily removable contamination removed or fixed (Fabrifilm ${ }^{1}$, Butvar ${ }^{2}$, Polymeric Barrier System, Soil Sement, non-flammable foam, varnish, paint, etc.).

3. The radiation dose on the external surface of the self-container shall not exceed $10 \mathrm{mSv} / \mathrm{h}(1,000 \mathrm{mrem} / \mathrm{h})$. The radiation dose at $2 \mathrm{~m}$ from any point on the self-container shall not exceed $0.1 \mathrm{mSv} / \mathrm{h}(10 \mathrm{mrem} / \mathrm{h})$. At the driver location, the dose rate shall not exceed $0.02 \mathrm{mSv} / \mathrm{h}(2 \mathrm{mrem} / \mathrm{h})$ if the driver is not a trained radiological worker, or $0.05 \mathrm{mSv} / \mathrm{h}(5 \mathrm{mrem} / \mathrm{h})$ if the driver is a radiological worker. Because of the probable extended size of the source within the self-container it is possible that the dose rate will not fall rapidly with distance from the surface. Therefore, when dose rate measurements are performed to ensure that the self-container meets the acceptance criteria, special attention should be given to points $2 \mathrm{~m}$ from the container surface and at the driver location.

${ }^{1}$ Fabrifilm is a trademark of Turco Products, Incorporated.

${ }^{2}$ Butvar is a trademark of Solutia inc. 
4. The self-container is only authorized for shipment of fissile excepted material. Fissile excepted material consists of less than $15 \mathrm{~g}$ of the fissile radionuclides ${ }^{233} \mathrm{U}$, ${ }^{235} \mathrm{U},{ }^{239} \mathrm{Pu}$, and ${ }^{241} \mathrm{Pu}$ as defined in $49 \mathrm{CFR} 173.453(\mathrm{a})$.

5. No free liquids are permitted.

6. Contents shall not exceed $100 \mathrm{~A}_{2} \mathrm{~s}$ of radioactive material.

\subsubsection{Content Matrix}

Self-containers will be of various shapes and sizes enveloped by a $12 \mathrm{~m}(40 \mathrm{ft})$ long by $2.5 \mathrm{~m}(8 \mathrm{ft})$ wide by $3 \mathrm{~m}(10 \mathrm{ft})$ high cuboid and a $12 \mathrm{~m}(40 \mathrm{ft})$ long by $2.5 \mathrm{~m}(8 \mathrm{ft})$ diameter cylinder. The package weight for shipment under this SARP is $22,680 \mathrm{~kg}(50,000 \mathrm{lb})$. Package parameters specified above are for packages which can be transported by standard conveyances. Oversized packages having geometries and/or weights which exceed the specified parameters may be transported under this SARP under the conditions specified in Part A, Section 2.1. It is possible that the contamination could be distributed throughout the interior surfaces of the self-container so that the source could extend to the approximate dimensions of the equipment.

\subsubsection{Radioactive Materials}

The maximum radionuclide activity allowed is 100 times $A_{2}$. This is a Type $B$ quantity. The material may be fissile-excepted.

\subsubsection{Nonradioactive Materials}

The chemical form of the residual material within the self-container will be fixed and not capable of producing hazardous gases, such as hydrogen. No liquids of any kind, except for residual quantities that cannot be practically removed, will be allowed inside the container. 
HNF-3341 Rev. 0

\subsection{TRANSPORT SYSTEM}

\subsection{TRANSPORTER}

The self-container is transported by truck. The tiedown configuration, and three blocking and bracing configurations are presented to provide flexibility. The conveyance must have a concentrated and total load capacity equal to or greater than that of the package. Immediately before shipment, the trailer shall be visually inspected for damage or deficiency(ies) which may affect safety of the shipment. Any damage or deficiency(ies) which may affect safety of the shipment shail be corrected before transport.

\subsection{TIEDOWN SYSTEM}

The tiedown system shall prevent significant shifting of the package and prevent the package from tipping over or rolling off the conveyance. The package must remain on or within the conveyance under all normal conditions and when responding to emergency situations, short of an accident. These requirements account for maneuvering of the conveyance such as hard braking and response to emergency situations. The following additional requirements for packages transported under this SARP are:

Packages under $460 \mathrm{~kg}(1,000 \mathrm{lb})$ shall be secured in accordance with the requirements of 49 CFR 393.100.

Packages shall be centered on the width of the conveyance. The long axis of the package shall be placed on the long axis of the conveyance.

The surface of the conveyance shall be clean, dry, and free of any loose material, debris, and oils. All materials used to increase frictional resistance and the surface on which they are to be placed shall be clean, dry, and free of any loose material, debris, and oils.

The total aggregate strength of the securement system shall be no less than 0.75 times the weight of the package in any horizontal direction.

For securement, vertical tiedown angles shall be no less than $30^{\circ}$ off the deck of the conveyance and horizontal tiedown angle shall be no less than $45^{\circ}$. Tiedowns shall be tightened with ratchet binders or other tightening devices, and must be taunt with no visible slack in any of the legs.

To restrain horizontal movement and reduce tiedown loads all packages shall be blocked and braced in all horizontal directions. Blocking and bracing shall be accomplished by either chock blocks secured to the deck of the conveyance or with chocking chains or with a combination of the two. As a supplement to blocking and bracing and to reduce loads, friction increasing commercial load mats are acceptable for use. However, the mating surface of the mats and package shall be clean, dry, and free of loose material and debris. Also, to increase frictional resistance for chocking chains, rubber padding or wood blocks shall be placed between the package and the chains. Mats and padding shall be protected from sharp edges, as necessary.

Cradles shall be provided for spherical or cylindrical shaped packages to prevent load shifts due to rolling. The ratio between the cradle and cylinder contact $(W)$ to the diameter of the cylinder (D) shall be equal to or greater than 5 to 8 , which is equivaient to a wedge angle of $39^{\circ}$ (see Figure A4-1). Also the minimum overall height of the cradles shall no less than $1 / 5$ the distance between the cradles. 
Figure A4-1, Cradle Schematic.

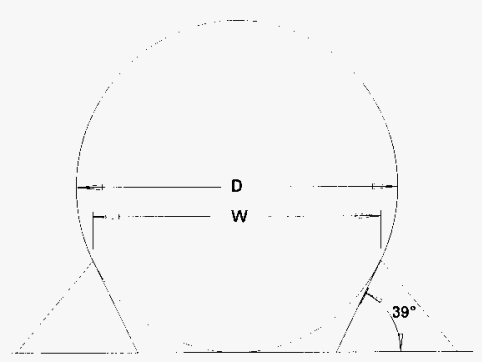

The total aggregate working load limit of the tiedowns shall be no less than 0.75 times the weight of the package in any direction. On each tiedown leg, couplings and binders shall have a rated working load equal or greater than the working load limit of the tiedown. Attachment of the tiedowns shall be to the main structure of the conveyance to the maximum extent practical or to D-rings or other tiedown points provided on the conveyance. Attachment shall not be made to stake pockets and attachment to rub rails shall be avoided. When attaching to the rub rails is necessary, attachment shall be made not to the rub rail itself but to the structural member extending from the conveyance side beams on which the rub rail is attached.

Chock chains and blocking shall have a capacity no less than 0.75 times the weight of the package in the direction of loading. Chains used for chocking shall have a minimum working load limit of 0.75 times the weight of the package. On each leg of the chocking chains couplings, shackles, D-rings, and binders shall have a rated working load limit equal or greater than the chain. Attachment to the conveyance shall follow the same guidelines as established above. When lumber is used for cradles and blocking, there shall be sufficient length and size of lumber to limit the compressive load on the wood to $12.9 \mathrm{~cm}^{2}\left(2 \mathrm{in}^{2}\right)$ per $460 \mathrm{~kg}(1,000 \mathrm{lb})$ of load. The lumber shall be commercial grade, straight-grained and free of decay and strength impairing knots. As a minimum, each length of lumber shall be secured the deck of the conveyance with twelve (12) $16 \mathrm{~d}$ nails. The lumber shall have predrilled nail holes which are staggered with a minimum spacing of $10 \mathrm{~cm}(4 \mathrm{in.}$. The nails shall be driven at right angles to the conveyance deck.

On the Hanford Site the most common tiedowns are $1 / 2$ in alloy chains with a working load limit of $5,900 \mathrm{~kg}(13,000 \mathrm{lb})$ which are used in combination with ratchet binders with a working load limit of $5,900 \mathrm{~kg}(13,000 \mathrm{lb})$. In most cases this chain size will meet the requirements set forth in this section. However, when loadings require higher working load limits, multiple chains and binders may be used to provide the required working load limit. When multiple chains are used that have common attachment end points or wrap around the package (i.e., chock chains), they shall be of the same length and tied together at the ends with shackles or D-rings.

\subsection{SPECIAL TRANSFER REQUIREMENTS}

\subsubsection{Routing and Access Control}

The self-container will be shipped on the Hanford Site by truck. No special routing is applied. Road closure to prevent public access to the shipment is required south of the Wye Barricade. 


\subsubsection{Radiological Limitations}

The radiation dose on the external surface of the self-container shall not exceed $10 \mathrm{mSv} / \mathrm{h}$ $(1,000 \mathrm{mrem} / \mathrm{h})$. The radiation dose at $2 \mathrm{~m}$ from any point on the self-container shall not exceed $0.1 \mathrm{mSv} / \mathrm{h}(10 \mathrm{mrem} / \mathrm{h})$. At the driver location the dose rate shall not exceed $0.02 \mathrm{mSv} / \mathrm{h}$ $(2 \mathrm{mrem} / \mathrm{h})$ if the driver is not a trained radiological worker, or $0.05 \mathrm{mSv} / \mathrm{h}(5 \mathrm{mrem} / \mathrm{h})$ if the driver is a radiological worker. Because of the probable extended size of the source within the self-container it is possible that the dose rate will not fall rapidly with distance from the surface. Therefore, when dose rate measurements are performed to insure that the self-container meets the acceptance criteria, special attention should be given to points $2 \mathrm{~m}$ from the container surface and at the driver location.

External contamination limits shall be per Table A4-1.

Table A4-1. Removable External Radioactive Contamination--Wipe Limits.

\begin{tabular}{|l|c|}
\hline \multicolumn{1}{|c|}{ Contaminant } & $\begin{array}{c}\text { Maximum permissible } \\
\text { limit }\left(\mathrm{dpm} / 100 \mathrm{~cm}^{2}\right)\end{array}$ \\
\hline $\begin{array}{l}\text { Beta-gamma emitting radionuclides; all radionuclides with haff lives less than } \\
\text { ten days; natural uranium; natural thorium; }{ }^{235} \mathrm{U},{ }^{238} \mathrm{U},{ }^{232} \mathrm{Th},{ }^{228} \mathrm{Th} \text {, and }{ }^{230} \mathrm{Th} \\
\text { when contained in ores or physical concentrates. }\end{array}$ & 2200 \\
\hline All other alpha emitting radionuclides. & 220 \\
\hline
\end{tabular}

Source: 49 CFR 173.443, 1997, "Shippers--General Requirements for Shipments and Packagings, Code of Federal Regulations, as amended.

\subsubsection{Time Restrictions}

No time restrictions are necessary.

\subsubsection{Speed Limitations}

No special speed limitations are applied to the self-container shipments. The posted speed limit shall govern the transportation.

\subsubsection{Environmental Conditions}

No shipments shall be made when the outdoor temperature is below $5^{\circ} \mathrm{C}\left(40^{\circ} \mathrm{F}\right)$ or during periods of expected heavy traffic, dense fog or adverse road conditions (such as snow or ice).

\subsubsection{Frequency of Use and Mileage Limitations}

There are no frequency or mileage limitations. 
HNF-3341 Rev. 0

\subsubsection{Escort and Emergency Response}

Emergency responders shall be notified before shipment of the self-container. 


\subsection{ACCEPTANCE OF PACKAGING FOR USE}

\subsection{NEW PACKAGING}

The self-container is equipment that has been in service, and therefore is not "new." However, to qualify for shipment under this SARP, it must be in good condition and able to withstand NTC. The shipper shall inspect each self-container to verify that it is in good condition. The self-container shall be visually inspected for damage or deficiency(ies) which may affect safety of the shipment. Any damage or deficiency(ies) which may affect safety of the shipment shall be corrected before transport.

Openings shall be closed in a manner to retain contents during routine transport as follows:

1. Smali round openings or small pipes shall be capped with tubing or pipe fittings.

2. All other openings shall be closed with a piece of metal either continuously welded or bolted over the openings. The resulting closure shall meet the minimum thickness requirements of Table A2-1.

3. The shipper shall assure that materials used for closure will be compatible with the container, other closure materials, and any container contents.

\subsection{PACKAGING FOR REUSE}

The self-container is intended to be a single-use shipment. To facilitate disposition, multiple onsite transfers are allowed at approved facilities. 
HNF-3341 Rev. 0

This page intentionally left blank.

A5-2 
HNF-3341 Rev. 0

\subsection{OPERATING REQUIREMENTS}

\subsection{GENERAL REQUIREMENTS}

The following procedures are provided to ensure compilance with the minimum requirements of this SARP. The shipping organization is responsible for ensuring the procedures shown below are performed and appropriate records are maintained.

\subsection{LOADING PACKAGE}

1. Identify the self-container. Ensure it meets the description of Part A, Section 2.0.

2. Remove waste material from the interior of the self-container that is readily removable.

3. Fix radioactive material within the self-container, as applicable.

4. Verify the radioactive contents meet the requirements of Part A, Section 3.0.

5. Seal all openings, as necessary, in accordance with Part A, Section 5.0.

6. Verify the radiological limits of Part A, Section 4.3 are met.

\subsection{LOADING PACKAGE}

1. Verify the transfer vehicle bed is of sufficient dimensions to allow the container to fit properly and not overhang on the end or sides.

2. Lift the self-container onto the transfer vehicle per the Hanford Site Hoisting and Rigging Manual (RL 1993).

3. Restrain the selt-container on the vehicle bed to prevent movement during normal transfer conditions, in accordance with Part A, Section 4.2

\subsection{UNLOADING PACKAGE}

1. After transfer to the storage or disposal site and prior to lifting off the transfer vehicle, the package shall be inspected again to verify that it is in good condition. There shall be no indications of damage to any part of the package. For packages that have indication of damage, repair of and/or precautions shall be used, as practical, based on radiological, as low as reasonable achievable (ALARA), and operational considerations.

2. Lift the package off the transfer vehicle using slings and an overhead hoist (crane, cherry picker),or a forklift, and transfer to the storage or disposal area.

\subsection{EMPTY PACKAGE (PACKAGING)}

The self-container will not be shipped as an empty package. 
HNF-3341 Rev. 0

This page intentionally left blank.

A6-2 


\subsection{QUALITY ASSURANCE REQUIREMENTS}

\subsection{INTRODUCTION}

This section describes the Quality Assurance (QA) requirements for the use of the selfcontainer. The requirements are taken from HNF-MP-599, Project Hanford Quality Assurance Program Description las implemented via Project Hanford Management Contract [PHMC] procedures\}; ENG-QAPP-001, Quality Assurance Program Plan for Project Hanford Management Contract Work, Engineering; TL-QAPP-001, Quality Assurance Program Plan for Project Hanford Management Contract Work, Transportation Logistics Business Unit.

\subsection{GENERAL REQUIREMENTS}

These requirements apply to activities that could affect the safety basis or quality of the self-container. The self-container is assigned Transportation Hazard Index (THI) and subordinate Quality Levels (QLs) in accordance with HNF-PRO-154.

\subsection{ORGANIZATION}

The organizational structure and the assignment of responsibility shall be such that quality is achieved and maintained by those who have been assigned responsibility for performing work. Quality achievement is to be verified by persons or organizations not directly responsible for performing the work.

WMNW Engineering and cognizant user managers are responsible for the quality of the work performed by their respective organizations and for performing the following activities:

- Follow current requirements of this SARP, HNF-MP-599, and applicable PHMC procedures.

- Provide instructions for implementing $Q A$ requirements.

The Vice President, Fluor Daniel Hanford, Inc. (FDH), QA, is responsible for developing and administering the PHMC QA Program as stated in HNF-MP-599.

\subsection{QUALITY ASSURANCE ACTIVITIES}

Each individual involved with use of the self-container is responsible for ensuring that the assigned tasks are performed in accordance with controlling plans and procedures, which must, in turn, conform to the requirements of this section of the SARP. QA requirements for tasks are determined and documented in the plans and procedures used by the involved organizations.

Requirements are imposed on organizations by direct reference in plans and procedures. Table A7-1 shows documentation review requirements. This matrix assigns responsibility for review and approval to the appropriate organization using the self-container. 
Table A7-1. Functional Responsibility Matrix.

\begin{tabular}{|l|c|c|}
\hline \multicolumn{1}{|c|}{ Document } & $\begin{array}{c}\text { Waste Management } \\
\text { Federal Services, Inc., } \\
\text { Northwest Operations }\end{array}$ & User \\
\hline $\begin{array}{l}\text { Self-Container Safety Analysis Report for } \\
\text { Packaging }\end{array}$ & P,R,A & R,A \\
\hline Operating procedures & $\mathrm{R}$ & $\mathrm{R}, \mathrm{A}$ \\
\hline
\end{tabular}

A = Approval

$\mathrm{P}=$ Primary responsibility (organization responsible for developing the document).

$\mathbf{R}=$ Review .

\subsection{TRANSPORTATION HAZARD INDEX AND QUALITY LEVELS}

The self-container is assigned THI of 3 based upon criteria established in HNF-PRO-154.

The alphanumeric OL. defines the significance to safety of each component of a packaging system. QLs are defined as follows.

QL-A: Critical impact on safety and associated functional requirements: items or components whose single failure or malfunction could directly result in an unacceptable condition of containment, shielding, or nuclear criticality control.

QL-B: Impact on safety and associated functional requirement: components whose failure or malfunction in conjunction with one other independent failure or malfunction could result in an unacceptable condition of containment, shielding, or nuclear criticality control.

Ql-C: Minor impact on safety and associated functional requirements: components whose failure or malfunction would not reduce packaging effectiveness and would not result in an unacceptable condition of containment, shielding, or nuclear criticality control regardless of other single failures.

Because the contents of the self-container are fixed, there is no single failure that would cause a lost of containment or shielding. The self-container should be treated as QL-C, and sealing material as $\mathrm{QL}-\mathrm{C}$.

\subsection{QUALITY REQUIREMENTS}

\subsubsection{QA Records and Document Control}

Records that furnish documentary evidence of quality shall be specified, prepared, and maintained per HNF-PRO-224, Document Control. All documents used to perform and/or verify quality-related activities shall be controlled.

The cognizant engineer is responsible for ensuring accessibility to the latest issue of all such documents.

All records associated with hazardous material packaging and transportation shall be retained for the life of the packaging. All lifetime storage $Q A$ records required for the self-container shall be appropriately stored by the responsible user organization (see Table A7-2). 
HNF-3341 Rev. 0

Table A7-2. Retention and Location Matrix.

\begin{tabular}{|l|c|c|}
\hline \multicolumn{1}{|c|}{ Document } & Retention period & Location \\
\hline Self-Container Safety Analysis Report for Packaging & Lifetime & DRM \\
\hline Inspection plans/procedures & Lifetime & User facility \\
\hline Operating procedures & Lifetime & User facility \\
\hline QA/OC inspection reports & Lifetime & QA/ISS \\
\hline Nonconformance reports & Lifetime & QA/ISS \\
\hline Specification and drawings & Lifetime & User/ISS \\
\hline Purchase orders & Lifetime & Procurement/ISS \\
\hline Data acquisition report & Lifetime & User/ISS \\
\hline Data packages & Lifetime & User/ISS \\
\hline Corrective action reports & Lifetime & User/ISS \\
\hline
\end{tabular}

DRM = Documentation and Records Management

ISS = Information and Scientific Systems.

$\mathrm{QA}=$ Quality Assurance.

$\mathrm{QC}=$ Quality Control.

\subsection{SARP CONTROL SYSTEM}

This SARP shall be copy controlled in accordance with HNF-PRO-225, Distributing Copy-Controlled Unclassified Documents, to ensure that only up-to-date approved versions are used. Any changes made to this SARP will be by engineering change notices (ECNs) in accordance with HNF-PRO-440, Engineering Document Change Control Requirements, which are distributed to users through the copy control system.

Any review comment records produced during the initial release or subsequent changes will be on file with WMNW Engineering. 
HNF-3341 Rev. 0

This page intentionally left blank.

A7-4 
HNF-3341 Rev. 0

\subsection{MAINTENANCE}

\subsection{GENERAL REQUIREMENTS}

Because the self-container package is authorized on a single-trip basis only, periodic maintenance becomes a use and storage consideration, and is therefore beyond the scope of this SARP. Inspection requirements prior to shipment are documented in Part A, Section 6.0. 
HNF-3341 Rev. 0

This page intentionally left blank.

AB-2 
HNF-3341 Rev. 0

\subsection{REFERENCES}

49 CFR 173, 1997, "Transportation," Code of Federal Regulations, as amended.

49 CFR 393, 1995, "Protection Against Shifting or Falling Cargo," Code of Federal Regulations, as amended.

ENG-QAPP-001, Quality Assurance Program Plan for Project Hanford Management Contract Work, Engineering, Waste Management Federal Services, Inc., Northwest Operations, Richland, Washington.

HNF-MP-599, Project Hanford Quality Assurance Program Description, Fluor Daniel Hanford, Inc., Richland, Washington.

HNF-PRO-154, Responsibilities and Procedures for All Hazardous Material Shipments, Fluor Daniel Hanford, Inc., Richland, Washington.

HNF-PRO-224, Document Control, Fluor Daniel Hanford, Inc., Richland, Washington.

HNF-PRO-225, Distributing Copy-Controlled Unclassified Documents, Fluor Daniel Hanford, Inc., Richland, Washington.

HNF-PRO-440, Engineering Document Change Control Requirements, Fluor Daniel Hanford, Inc., Richland, Washington.

TL-QAPP-001, Quality Assurance Program Plan for Project Hanford Management Contract Work, Transportation Logistics Business Unit, Waste Management Federal Services, Inc., Northwest Operations, Richland, Washington.

RL, 1993, Hanford Site Hoisting and Rigging Manual, DOE-RL-92-36, U.S. Department of Energy, Richland Operations Office, Richland, Washington. 
HNF-3341 Rev. 0

This page intentionally left blank.

A9-2 
HNF-3341 Rev. 0

PART B: PACKAGE EVALUATION

\subsection{INTRODUCTION}

\subsection{SAFETY EVALUATION METHODOLOGY}

The Decontaminated Equipment Self-Container (herein referred to as the self-container) Safety Analysis Report for Packaging (SARP) is intended to be used for onsite transport of equipment that can be decontaminated sufficiently to meet the requirements of HNF-PRO-154, Responsibilities and Procedures for All Hazardous Material Shipments, without additional packaging.

The normal transport conditions (NTC) are based on Site conditions and the inherent variability of the self-container. Since they cannot be preanalyzed to verify accident capability, self-containers are conservatively assumed to fail if in an accident.

Additional securement requirements are imposed in the tiedown section (Part B, Section 10.0) to supplement 49 CFR 393.100 requirements.

\subsection{EVALUATION SUMMARY AND CONCLUSIONS}

The self-container meets the onsite transportation safety requirements of HNF-PRO-154.

\subsubsection{Contents}

The self-container contains only residual contamination on interior surfaces following decontamination. The self-container will not contain liquids, fissile material, hydrogen gas generating materials, or materials such as volatile organic compounds that can produce gas and undue pressure within the container.

\subsubsection{Radiological Risk}

The risk evaluation shows the self-container meets the dose consequence limits for a Transportation Hazard Index (THI) 3 package.

\subsubsection{Containment}

Content retention is accomplished by closing openings in a manner to retain contents during normal transport conditions.

\subsubsection{Shielding}

Any shielding is provided by the self-container. Measurement is required to verify the dose rates are below the acceptance criteria. 


\subsubsection{Criticality}

There is no criticality hazard for the self-container because fissile material content is restricted to less than $15 \mathrm{~g}$.

\subsubsection{Structural}

Self-containers are defined, in structural terms, as packages which have sufficient structural integrity to retain its contents under NTC.

\subsubsection{Thermal}

Self-containers have no significant internal heat loading

\subsubsection{Pressure and Gas Generation}

The self-container is not permitted to contain chemical forms, such as organic liquids and solids, or hydrogenous materials, that can produce hazardous gases like hydrogen. Therefore, there are no hazards associated with pressure build-up or flammable gases.

\subsubsection{Tiedown System}

In application of this SARP, the underlying premise is that the package remains on the conveyance for all NTC.

\subsection{REFERENCE}

HNF-PRO-154, Responsibilities and Procedures for All Hazardous Material Shipments, Fluor Daniel Hanford, Inc., Richland, Washington. 
HNF-3341 Rev. 0

\subsection{CONTENTS EVALUATION}

\subsection{CHARACTERIZATION}

The self-container is equipment to be transported that contains residual contamination on interior surfaces without additional packaging.

It is expected that a variety of decontaminated equipment will qualify as self-containers for transportation on the Hanford Site. Therefore, it is not possible to specify a source term based on a specific set of radionuclides with given relative residual concentrations in the decontaminated equipment. However, experience has shown that the radionuclides that occur with greatest activity are ${ }^{137} \mathrm{Cs}$ and ${ }^{90} \mathrm{Sr}$ and associated progeny ${ }^{137 \mathrm{~m}} \mathrm{Ba}$ and ${ }^{90} \mathrm{Y}$, respectively. Further discussion of the source term development is in Part B, Section 4.5.3.

\subsection{RESTRICTIONS}

The self-container will not contain liquids, fissile materials, hydrogen-gas generating materials, or materials such as volatile organic compounds that can produce gases and undue pressure within the container.

The source term will be Type $B$, fissile excepted (less than $15 \mathrm{~g}$ fissile radionuclides), and will be less than $100 \mathrm{~A}_{2}$ values as defined in $49 \mathrm{CFR} 173$. The limit is chosen such that the dose consequence from a hypothetical release of material meets the onsite transportation safety acceptance criteria. At the same time the limit does not overly restrict the transportation of self-containers onsite. If more than one radionuclide is present in the contaminated material, the sum of the $A_{2}$ fractions is used to calculate the total number of $A_{2} s$.

Exterior surfaces of the self-container will be decontaminated or fixed with an approved fixant to removable contamination values less than $2200 \mathrm{dpm} / 100 \mathrm{~cm}^{2}$ for beta-gamma emitting radionuclides and less than $220 \mathrm{dpm} / 100 \mathrm{~cm}^{2}$ for alpha emitting radionuclides (49 CFR 173.443).

\subsection{SIZE AND WEIGHT}

Self-containers will be of various shapes and sizes enveloped by a $12 \mathrm{~m}(40 \mathrm{ft})$ long by $2.5 \mathrm{~m}(8 \mathrm{ft})$ wide by $3 \mathrm{~m}(10 \mathrm{ft})$ high cuboid and a $12 \mathrm{~m}(40 \mathrm{ft})$ long by $2.5 \mathrm{~m}(8 \mathrm{ft})$ diameter cylinder. The package weight for shipment under this SARP is $22,680 \mathrm{~kg}(50,000 \mathrm{lb})$. Package parameters specified above are for packages which can be transported by standard conveyances. Oversized packages having geometries and/or weights which exceed the specified parameters may be transported under this SARP under the conditions specified in Part A, Section 2.1. It is possible that the contamination could be distributed throughout the interior surfaces of the self-contained equipment so that the source could extend to the approximate dimensions of the equipment.

\subsection{REFERENCE}

49 CFR 173, 1995, "Transportation," Code of Federal Regulations, as amended. 
HNF.3341 Rev. 0

This page intentionally left blank.

B2-2 
HNF-3341 Rev. 0

\subsection{RADIOLOGICAL RISK EVALUATION}

\subsection{INTRODUCTION}

The self-container will transport a Type B quantity of radioactive material on the Hanford Site. Radiological risks are evaluated to determine compliance with onsite transportation safety requirements per HNF-PRO-154.

The assumptions for the radiological risk evaluation are the following:

- Highway mode.

- Closed roads when traveling south of the Wye Barricade.

The self-container must meet onsite transportation safety requirements as outlined in HNF-PRO-154 and Mercado (1994). The requisite safety is determined by an evaluation that uses dose consequences, risk acceptance criteria, and Hanford Site accident frequencies. For the evaluation, accidents are categorized as impact, crush, puncture, and fire. Risk acceptance criteria are outlined in Part B, Section 3.2. The dose consequence analyses results are discussed in Part B, Section 3.3. The analysis of accident release frequencies is given in Part B, Section 3.5. The accident frequencies, together with the dose consequence values, provide the necessary input to provide an evaluation of acceptance of the risk related to transporting the self-container.

\subsubsection{Summary of Results}

Because the self-containers by definition cannot be assumed to withstand accident conditions, the total conditional probability of release for mechanical and thermal accident scenarios was assumed to be $100 \%$ (i.e., the self-container is assumed to fail in an accident). The total conditional release probability was then multiplied by the Hanford Site annual accident rate to arrive at an annual accident release frequency. The annual release frequency was compared to the dose consequence results to determine acceptance (HNF-PRO-154, Mercado 1994). For the self-container, the predicted maximum dose consequences fall below the acceptance criteria for a THI 3 package. Consequently, there are no further use restrictions to comply with onsite transportation safety requirements.

\subsection{RISK ACCEPTANCE CRITERIA}

Graded dose limitations for probable, credible, and incredible accident frequencies ensure safety in radioactive material packaging and transportation (Mercado 1994). The dose limits for the offsite and onsite receptor for probable, credible, and incredible accident frequencies are presented in Table B3-1. 
Table B3-1. Risk Acceptance Criteria Limits (Effective Dose Equivalent).

\begin{tabular}{|l|c|c|c|}
\hline \multicolumn{1}{|c|}{ Description } & Annual frequency & $\begin{array}{c}\text { Onsite dose limit" } \\
\text { Sv (rem) }\end{array}$ & $\begin{array}{c}\text { Offsite dose limit } \\
\text { Sv (rem) }\end{array}$ \\
\hline Incredible & $<10^{-7}$ & None & None \\
\hline Incredible & $10^{-7}$ to $<10^{-6}$ & None & $0.25(25)$ \\
\hline Credible & $10^{-6}$ to $10^{-3}$ & $0.05(5)$ & $0.005(0.5)$ \\
\hline Probable & $1 \times 10^{-3}$ to 1 & $0.002(0.2)$ & $0.0001(0.01)$ \\
\hline
\end{tabular}

*Effective dose equivalent.

\subsection{DOSE CONSEQUENCE ANALYSIS RESULTS}

The dose consequence evaluation for the self-container is discussed in Part B, Section 4.5. The evaluation considers the results of an accident to the self-container that involves fire. The dose consequence results are shown in Table B3-2 for a ground-level release at the worst location with the worst-case $(0.5 \%)$ meteorology. The dose calculated is the total committed effective dose equivalent (TEDE), which is integrated over 50 years.

Table B3-2. Summary of Dose Consequence Results.

\begin{tabular}{|l|c|c|}
\hline \multicolumn{1}{|c|}{ Exposure pathway } & $\begin{array}{c}\text { Hanford Site worker } \\
\text { Sv (rem) }\end{array}$ & $\begin{array}{c}\text { Maximum public receptora } \\
\text { Sv (rem) }\end{array}$ \\
\hline External photon dose & $2.5 \mathrm{E}-3(0.25)$ & NA \\
\hline External dose from beta particles & $5.1 \mathrm{E}-3(0.51)$ & NA \\
\hline $\begin{array}{l}\text { Inhalation and submersion airborne transport } \\
\text { pathway }\end{array}$ & $0.018(1.8)$ & $3.5 \mathrm{E}-4(0.035)$ \\
\hline $\begin{array}{l}\text { Skin contamination and ingestion from handling } \\
\text { package contents }\end{array}$ & NA & NA \\
\hline Submersion dose from gaseous vapor & NA & NA \\
\hline Total TEDE & $0.026(2.6)$ & 3.5 E-4 (0.035) \\
\hline
\end{tabular}

TEDE = Total committed effective dose equivalent.

Note: $100 \mathrm{rem}=1 \mathrm{~Sv}$.

${ }^{2}$ The maximum public receptor dose is located $100 \mathrm{~m} \mathrm{~N}$ of the release point in the 300 Area.

The analysis shows that the dose to the maximum public receptor is less than $0.005 \mathrm{~Sv}$ $(0.05 \mathrm{rem})$ and the dose to the site worker is less than $0.05 \mathrm{~Sv}$ (5 rem). Thus, the self-container is assigned a THI of 3 .

\subsection{FAILURE THRESHOLD ANALYSIS}

Because the performance capabilities of the self-container under accident conditions were not evaluated, it is conservatively assumed that the self-container fails and releases the contents in any accident (impact, puncture, crush, or fire). 
HNF-3341 Rev. 0

\subsection{ACCIDENT FREQUENCY ASSESSMENT}

\subsubsection{Approach}

The accident release frequency assessment is based on the assumption that all failure modes from the different forces described as impact, puncture, crush, and fire result in the same level of consequence. The union of the package conditional release probabilities from different scenarios with similar consequences is multiplied by the frequency of truck accidents to arrive at a total accident release frequency.

The frequency $(F)$ of a truck accident is the product of the annual number of trips, the number of miles per trip, and the accident rate per mile.

$$
F=\frac{\text { number of trips }}{\text { year }} \times \frac{\text { miles }}{\text { trip }} \times \frac{\text { accidents }}{\text { mile }}
$$

Hanford Site truck accidents have been compiled in a report using Site-specific data (Green et al. 1996) which gives the accident rate for trucks as $2.0 \times 10^{-7}$ accidents per mile. For a shipment of radioactive materials north of the Wye Barricade which is carried out by trained truck drivers during daylight hours in good road conditions, a total reduction factor of 40 can be applied to lower the rate to $5 \times 10^{-9}(\mathrm{H} \& \mathrm{R} 1995)$ accidents per mile. Appendix B of Recommended Onsite Transportation Risk Management Methodology (H\&R 1995) summarizes statistics from the U.S. Department of Transportation (DOT) and the studies conducted by Sandia National Laboratory on accident responses of small and large packages. The H\&R report recommends reducing truck accident rates by 10 for "safe" truck drivers, a factor of two for travel north of the Wye barricade and another factor of two for shipment of radioactive material. Travel south of the Wye barricade will occur only on closed roads which may reduce accidents by another factor of 20 . However this closed road reduction factor conservatively taken to be 2 . The reduction factors are based on the following logic:

- Safe truck drivers: Hanford Site truck drivers have special training. Drivers must complete several driver's education courses, have a valid commercial driver's license with hazardous endorsement, complete specific training for highway route controlled quantities of radioactive material, and complete radiation worker and hazardous materials training. References show that drivers that participate in special safety programs reduce single-vehicle accident rates by up to a factor of 100 . The H\&R report (H\&R 1995) recommends using an overall accident reduction factor of 10.

- Travel north of the Wye Barricade: The general population is excluded north of the Wye barricade. The roads are straight and generally flat. These conditions eliminate conditions caused by after-work activities, such as alcohol consumption and travel during limited visibility. Statistics show that the difference between travel during day and night leads to an accident reduction of 2.67. Therefore, although the self-container is not limited to travel during daylight hours, a conservative factor of two reduction is recommended for travel north of the Wye Barricade because there is a constraint on traveling during adverse weather conditions which may affect visibility, and because no alcohol consumption is permitted on the Hanford Site. 
- Travel south of the Wye Barricade: Travel will occur south of the Wye Barricade on closed roads. Road closure reduces rear-end collision by a factor of 10 and multiple-vehicle accidents are reduced by another factor of 20 . However, only a reduction factor of 2 is applied in this analysis in order to be consistent with the approach to the portion of the shipment north of the Wye Barricade.

- Radioactive material: An additional factor of two is recommended based on the higher level of training required for drivers of vehicles carrying radioactive material and the higher level of caution that would be expected from drivers of cargos consisting of radioactive material.

The calculated accident frequency is multiplied by the conditional release probability, discussed in Part B, Section 3.5.2 to arrive at an annual accident release frequency.

\subsubsection{Accident Release Frequency Analysis}

Values for the probability of occurrence and conditional probabilities of failure are taken from Severities of Transportation Accidents involving Large Packages (Dennis et al. 1978), Severities of Transportation Accidents Volume III - Motor Carriers (Clarke et al. 1976), and H\&R (1995). Scenarios, such as immersion, which are not pertinent to the shipment of radioactive material on the Hanford Site are not included in the model.

3.5.2.1 Conditional Release Probabilities. The conditional probability of release, given an accident, is conservatively assumed to be $\mathbf{1 . 0}$ for the self-container; that is, the self-container is assumed to fail in any accident.

\subsection{EVALUATION AND CONCLUSION}

The conditional release probability $(1.0)$ is multiplied by $F$, the frequency, to arrive at an accident release frequency of $5 \times 10^{-9} / \mathrm{mi}$. Self-containers are rarely transported, and it is not expected that the total annual mileage would exceed 1000 miles. This indicates an annual release frequency of $5 \times 10^{-6}$. At this frequency, the predicted dose consequence meets the waste transportation acceptance criteria.

\subsection{REFERENCES}

Clarke, R. K, J. T. Foley, W. F. Hartman, and D. W. Lawson, 1976, Severities of Transpartation Accidents Volume II--Motor Carriers, SLA-74-0001, Sandia Laboratories, Albuquerque, New Mexico.

Green, J. R., B. D. Flanagan, and H. Harris, 1996, Hanford Site Truck Accident Rate, 1990-1995, WHC-SD-TP-RPT-021, Rev. O, Westinghouse Hanford Company, Richland, Washington.

H\&R, 1995, Recommended Onsite Transportation Risk Management Methodology, 522-1, H\&R Technical Associates, Inc., Oak Ridge, Tennessee.

HNF-PRO-154, Responsibilities and Procedures for All Hazardous Material Shipments, Fluor Daniel Hanford, Inc., Richland, Washington.

Mercado, J. E., 1994, Report on Equivalent Safety for Transportation and Packaging of Radioactive Materia/s, WHC-SD-TP-RPT-001, Rev. 0, Westinghouse Hanford Company, Richland, Washington. 


\section{CHECKLIST FOR CHECKING OF ANALYSIS/CALCULATIONS}

Document Number/Revision: HNF-3341, Bev, 0

Document Title: SARP 10 nsitel Decontaminated Equipment Self-Container Section 3.0 Radiological Risk Evaluation

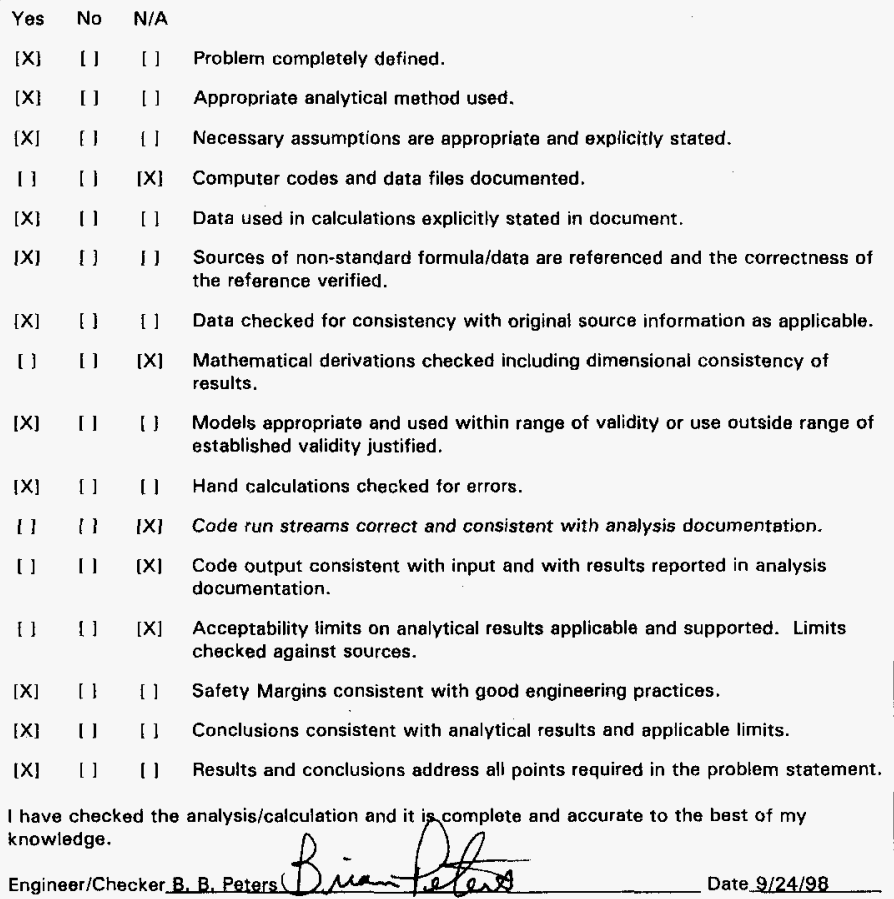

NOTE: Any hand calculations, notes or summaries generated as part of this check should be signed, dated, and attached to this checklist. Material should be labeled and recorded so that it is intelligible to a technically qualified third party. 
HNF-3341 Rev. 0

This page intentionally left blank.

B3-6 
HNF-3341 Rev, 0

\subsection{CONTAINMENT EVALUATION}

\subsection{INTRODUCTION}

The self-container is a piece of existing equipment that has internal, essentially fixed contamination. Any opening through which contamination could exit is sealed. Content retention is based on the form of the radioactive contents and the nature of the self-container.

\subsection{CONTAINMENT SOURCE SPECIFICATION}

The radioactive source is essentially fixed internal contamination not to exceed $100 \mathrm{~A}_{2} \mathrm{~s}$ of radioactive material (Type $\mathrm{B}$ ).

\subsection{NORMAL TRANSFER CONDITIONS}

\subsubsection{Conditions To Be Evaluated}

The self-container is evaluated in Part B, Section 7.0 as a single-use system. Vibration, handling, restraint loads, and penetration are analyzed.

\subsubsection{Containment Acceptance Criteria}

The self-container shall not rupture, fracture, or otherwise breech under normal transfer conditions.

\subsubsection{Summary of Results}

As shown in Part B, Section 7.0, the self-container, when developed and used in accordance with Part $A$, will retain the contents under normal transfer conditions.

\subsection{ACCIDENT CONDITIONS}

\subsubsection{Conditions To Be Evaluated}

Because of their nature, self-containers cannot be pre-analyzed to verify accident capability. Consequently, they are assumed to breech in an accident.

\subsubsection{Containment Acceptance Criteria}

The dose consequence acceptance criteria in Table B3-1 shall not be exceeded.

\subsection{ACCIDENT CONTAINMENT EVALUATION AND SUMMARY}

This section contains dose consequence calculations for the self-container. Table B4-1 summarizes the dose from each exposure pathway for the fire scenario. The fire scenario results 
bound those for the non-fire scenario; therefore, only the fire scenario results will be reported. These results apply to packages shipped anywhere on the Hanford Site. Table B4-1 provides the total dose for each receptor, which is obtained by summing the dose contributions from each pathway. Because the onsite worker dose is between $0.002 \mathrm{~Sv}(0.2 \mathrm{rem})$ and $0.05 \mathrm{~Sv}(5 \mathrm{rem})$, and the public receptor dose is between $0.0001 \mathrm{~Sv}(0.01 \mathrm{rem})$ and $0.005 \mathrm{~Sv}(0.05 \mathrm{rem})$, the self-container is a THI 3 package. The criteria for a THI of 3, as stated in HNF-PRO-154, is

"THI-3: This represents the second lowest level of hazard from the contents. A packaging system assigned this level transports material that has the potential of causing a dose consequence, to an individual, of between $0.01 \mathrm{rem}$ and $0.5 \mathrm{rem}$ at the Hanford Site boundary or between 0.2 rem and 5 rem within the site, if fully released."

Table B4-1. Summary of Doses From Each Pathway for Fire Scenario.

\begin{tabular}{|l|c|c|}
\multicolumn{1}{|c|}{ Exposure pathway } & $\begin{array}{c}\text { Hanford Site worker } \\
\text { Sv (rem) }\end{array}$ & $\begin{array}{c}\text { Maximum public receptora } \\
\text { Sv (rem) }\end{array}$ \\
\hline External photon dose & $2.5 \mathrm{E}-3(0.25)$ & NA \\
\hline External dose from beta particles & $5.1 \mathrm{E}-3(0.51)$ & NA \\
\hline $\begin{array}{l}\text { Inhalation and submersion airborne transport } \\
\text { pathway }\end{array}$ & $0.018(1.8)$ & $3.5 \mathrm{E}-4(0.035)$ \\
\hline $\begin{array}{l}\text { Skin contamination and ingestion from handling } \\
\text { package contents }\end{array}$ & NA & NA \\
\hline Submersion dose from gaseous vapor & NA & NA \\
\hline Total TEDE & $0.026(2.6)$ & 3.5 E-4 (0.035) \\
\hline
\end{tabular}

TEDE = Total committed effective dose equivalent.

Note: 100 rem $=1 \mathrm{~Sv}$.

The maximum public receptor dose is located $100 \mathrm{~m} \mathrm{~N}$ of the release point in the 300 Area.

\subsubsection{Introduction and Overview}

This SARP addresses the shipment of Type $B$, fissile excepted, decontaminated equipment containing a maximum of $100 \mathrm{~A}_{2} \mathrm{~s}$ of radioactive material anywhere on the Hanford Site. The results of this analysis are used to establish a THI for the package, and are used as input into the risk evaluation (see Part B, Section 3.0).

\subsubsection{Dose Consequence Analysis Methodology}

International Atomic Energy Agency (IAEA [1990]) defines a standardized approach for evaluating transportation packaging requirements, called the Q-system. The Q-system methods, as outlined in IAEA (1990), have been incorporated into a WHC document Report on Equivalent Safety for Transportation and Packaging of Radioactive Materials (Mercado 1994).

In the Q-system, the following five exposure pathways are considered: 1) external exposure to photons; 2) external exposure to beta particles; 3) inhalation; 4) skin contamination and ingestion; and 5) submersion in a cloud of gaseous isotopes. In special cases such as alpha particle or neutron emitters, other exposure routes are considered. In some cases a pathway will be judged to be small with respect to the others and consideration will be minimal. Modifications to the IAEA scenarios are incorporated to more closely describe the particular conditions of the 
shipment. Detailed calculations for the postulated accident are performed whenever possible. However, in some cases, the IAEA guide's worst case rules-of-thumb are used.

The Q-system was developed as an all-encompassing generalized methodology using only the isotope as the defining variable. In this report, the specifics of the package are considered. Some of the dose pathways may be considered incredible (frequency $<10^{-6} / \mathrm{yr}$ ), and although these pathways are covered in the IAEA guide, they are disregarded in the analysis.

In this IAEA system, the $Q$-values that are calculated are the radionuclide activities corresponding to each exposure route which causes the individual to receive the effective dose equivalent limit. The minimum $Q$-values define the $A_{2}$ values for the shipped materials. In the case of non-dispersible materials (limited by the $A_{1}$ values) only the first two $Q$-values (based on exposure to external photon and external beta particles) are used. Note that for all radiation except neutrons, protons, and heavier charged particles (including alpha particles), $1 \mathrm{~Gy}=1 \mathrm{~Sv}$, and 1 rad $=1 \mathrm{rem}$.

There are two receptors of interest in the Q-system. They are: the Hanford Site worker, and the offsite receptor. The Hanford Site worker is assumed to be located at or near the package. The offsite receptor is assumed to be located at the border of the Hanford reservation. For the offsite receptor, inhalation, ingestion, and direct exposure from submersion in a cloud are considered.

Part B, Section 4.5.3 addresses the source term, and Part B, Sections 4.5.4 through 4.5.9 discuss the dose consequence calculations for the Hanford Site worker and the offsite receptor for the five pathways of interest.

\subsubsection{Source Term}

Part B, Section 2.0 discusses the maximum allowable source term for the decontaminated equipment. The limiting criteria from a dose consequence standpoint is the limit of $100 \mathrm{~A}_{2} \mathrm{~s}$. The limiting radionuclide from a dose consequence standpoint is ${ }^{137} \mathrm{Cs}$; i.e., $100 \mathrm{~A}_{2} \mathrm{~s}$ of ${ }^{137} \mathrm{Cs}\left(5 \times 10^{13}\right.$ $\mathrm{Bq}$ or $1350 \mathrm{Ci}$ ) (49 CFR 173.435) yields the highest total dose to the worker and the public for the radionuclides normally encountered at the Hanford Site. It is recognized that other radionuclides exist which yield higher doses than ${ }^{137} \mathrm{Cs}$. However, these were screened out during the evaluation process because they are either not normally present on the Hanford Site (e.g. ${ }^{257} \mathrm{Fm}$, ${ }^{166 \mathrm{~m}} \mathrm{Ho}$, etc.), or they are present in relatively low concentrations (e.g., ${ }^{152} \mathrm{Eu},{ }^{93 \mathrm{~m}} \mathrm{Nb}$, etc.) compared to other fission or activation products, and the probability of any decontaminated equipment containing $100 \mathrm{~A}_{2} \mathrm{~s}$ of these radionuclides is very remote. If $100 \mathrm{~A}_{2} \mathrm{~s}$ of these low concentration radionuclides (e.g., ${ }^{152} \mathrm{Eu},{ }^{93 \mathrm{~m}} \mathrm{Nb}$ ) were present on decontaminated equipment, the activity of other more routinely encountered radionuclides (e.g., ${ }^{154} \mathrm{Eu},{ }^{137} \mathrm{Cs},{ }^{60} \mathrm{Co}$ ) that are normally associated with these radionuclides would be much greater than $100 \mathrm{~A}_{\mathrm{s}} \mathrm{s}$ due to the low concentration of these relative to the more routinely encountered radionuclides. Note that $100 \mathrm{~A}_{2} \mathrm{~s}$ of ${ }^{60} \mathrm{Co}\left(4 \times 10^{13} \mathrm{~Bq}\right.$ or $\left.1080 \mathrm{Ci}\right)$, which is a fairly common contaminant, yields a higher total dose than $100 \mathrm{~A}_{2} \mathrm{~s}{ }^{137} \mathrm{Cs}$ because of the high energy gammas emitted during decay. However, if an object were to contain that many curies of ${ }^{60} \mathrm{Co}$, the dose rate limit of $10 \mathrm{mSv} / \mathrm{h}(1000 \mathrm{mrem} / \mathrm{h})$ would very likely be exceeded; therefore, ${ }^{60} \mathrm{Co}$ was not selected as the limiting radionuclide. 


\subsubsection{External Dose Due to Photon (Gamma) Exposure}

The IAEA scenario assumes that a person is exposed to a damaged transport package following an accident. The shielding of the package is assumed to be completely lost in the accident. The external gamma exposure analysis is normally done assuming a person remains $3 \mathrm{~m}$ from the unshielded source for a period of 15 minutes.

Because of the form of radioactivity contained in the self-container, a worker will never be directly exposed to $100 \mathrm{~A}_{2} \mathrm{~s}$ of radioactive material from a damaged transport package following an accident. The dose rate limits for the self-container are $10 \mathrm{mSv} / \mathrm{h}(1,000 \mathrm{mrem} / \mathrm{h})$ on the surface, and $0.1 \mathrm{mSv} / \mathrm{h}(10 \mathrm{mrem} / \mathrm{h})$ at $2 \mathrm{~m}$ from the surface. This analysis assumes that a worker is exposed directly to the surface of the damaged transport package for 15 minutes, where the surface dose rate is at the limit of $10 \mathrm{mSv} / \mathrm{h}(1,000 \mathrm{mrem} / \mathrm{h})$. The use of the maximum surface dose rate limit in the analysis instead of the dose rate at $3 \mathrm{~m}$ conservatively accounts for an shielding of the radioactive material by the self-container since the analysis is normally done assuming an unshielded source. The total external gamma effective dose equivalent (EDE) for the worker is then $2.5 \mathrm{mSv}(250 \mathrm{mrem})$ for a 15 minute exposure period.

\subsubsection{External Dose Due to Beta Particle Emitters}

Because of the limited range of $\beta$-particles relative to that of photons, a shielding factor is used by the IAEA to account for residual shielding from material such as package debris. Except for this factor, no effort is made to account for either self-shielding or shielding from an accurate model of the damaged package. Shielding and dose rate factors are graphed in the IAEA Safety Guide No. 7 as a function of the maximum energy of the $\beta$-particle. The IAEA beta dose rate calculation methods are based on an individual located $1 \mathrm{~m}$ from the unshielded source.

This analysis assumes an individual remains at a distance of $3 \mathrm{~m}$ from the source for a 15 minute exposure period. A factor will be applied to the dose rates calculated using the IAEA method to account for the difference between the $1 \mathrm{~m}$ distance assumed in developing the shielding factors and the $3 \mathrm{~m}$ distance in this analysis. This factor was conservatively taken to be $0.333[(1 \mathrm{~m} / 3 \mathrm{~m})]$, since the dose rate falls off approximately as $1 / \mathrm{r}$ for large sources, where $r$ is the distance from the source. This also conservatively ignores any attenuation of the beta particles over the $3 \mathrm{~m}$ distance.

Table B4-2 provides the $\beta$-particle dose calculations for $100 \mathrm{~A}_{2} \mathrm{~s}$ of ${ }^{137} \mathrm{Cs}\left(5 \times 10^{13} \mathrm{~Bq}\right.$ or $1350 \mathrm{Ci}$ ). The total $\beta$-particle dose rate to the skin for an individual located $3 \mathrm{~m}$ from the source is $2.02 \mathrm{~Sv} / \mathrm{h}\left(2.02 \times 10^{2} \mathrm{rem} / \mathrm{h}\right)$. This results in a $\beta$-particle dose of $0.505 \times 10^{2} \mathrm{~Sv}(50.5 \mathrm{rem})$ to the skin for a 15 minute exposure. Since the tissue weighting factor for the skin is 0.01 (ICRP 1991), the whole body EDE is then $5.05 \times 10^{-3} \mathrm{~Sv}(0.505 \mathrm{rem})$. 
Table B4-2. $\beta$-Particle Dose Rate for Beta Emitters Contributing $>0.01 \%$ to the Total Dose.

\begin{tabular}{|c|c|c|c|c|c|c|c|c|}
\hline Isotope & $\begin{array}{c}\text { Activity } \\
\text { (Ci) }\end{array}$ & $\begin{array}{c}\text { Activity } \\
\text { (Bq) }\end{array}$ & $\begin{array}{c}\text { Branching } \\
\text { ratio }\end{array}$ & $E_{\max }(\mathrm{MeV})$ & $\begin{array}{c}\text { Dose rate } \\
\text { factor }^{\mathrm{B}}\end{array}$ & $\begin{array}{c}\text { Shielding } \\
\text { factor }^{\mathbf{b}}\end{array}$ & $\begin{array}{c}\text { Dose rate } \\
(\text { rem/h } / \mathrm{h})^{\mathrm{c}}\end{array}$ & $\%$ dose \\
\hline \multirow[t]{2}{*}{${ }^{137} \mathrm{Cs}$} & \multirow[t]{2}{*}{$1.35 E+03$} & \multirow[t]{2}{*}{$1.00 \mathrm{E}+12$} & 0.946 & 0.51155 & $1.8 \mathrm{E}-04$ & 100 & $7.66 \mathrm{E}+01$ & 37.90 \\
\hline & & & 0.054 & 1.17320 & 3.1E-04 & 6 & $1.26 \mathrm{E}+02$ & 62.10 \\
\hline \multicolumn{7}{|c|}{ Totals for Beta Emitters Contributing $>0.01 \%$} & $2.02 \mathrm{E}+02$ & 100.00 \\
\hline \multicolumn{7}{|c|}{ Totals for All Beta Emitters } & $2.02 E+02$ & 100.00 \\
\hline
\end{tabular}

Dose rate factor in units of $\mathrm{G} / \mathrm{h}$ or $\mathrm{Sv} / \mathrm{h}$ for a 1 mci source from IAEA (1990).

'Shielding factor from IAEA $\{1990)$.

Note that a factor of 0.333 is applied to the dose rates to account for a source-to-receptor distance of $3 \mathrm{~m}$ for this analysis, versus the $1 \mathrm{~m}$ distance assumed in the development of the dose rate factors from IAEA (1990).

IAEA, 1990, Explanatory Material for the IAEA Regulations for the Safe Transport of Radioactive Material, Safety Series No. 7, Second Edition (As Amended 1990), International Atomic Energy Agency, Vienna, Austria.

\subsubsection{Inhalation and Ingestion Dose}

Radioactive material may be inhaled following an accident due to resuspension or volatization of the material released from the package. This section addresses dose consequences from a postulated fire accident scenario which impacts the decontaminated equipment and results in an airborne release of radioactive material. The fire scenario results bound those for a non-fire scenario, therefore, only a fire scenario will be evaluated. The analysis applies to packages shipped anywhere on the Hanford Site.

4.5.6.1 Accident Release Quantity. Part B, Section 2.0 states that the waste material in the interior of the self-container that is readily removed has been removed, and that the remaining radioactive material is fixed to the extent possible and all external openings are sealed. DOE (1994) does not contain release fractions for decontaminated equipment under thermal stress conditions. However, for this evaluation the release fraction for contaminated non-combustible solids will conservatively be used although it is intended to be applied to loose surface contamination. The airborne release fraction (ARF) from DOE (1994) for contaminated non-combustible solids is $6 \times$ $10^{-3}$ and the respirable fraction (RF) is 0.01 . Therefore, an ARF $x$ RF will be used in this analysis $6 \times 10^{5}$. The total amount of respirable ${ }^{137} \mathrm{Cs}$ that is made airborne under the postulated thermal stress (fire) conditions is then simply $100 \mathrm{~A}_{2} \mathrm{~s}$ of ${ }^{137} \mathrm{Cs}\left(5 \times 10^{13} \mathrm{~Bq}\right.$ or $\left.1350 \mathrm{Ci}\right)$ times $6 \times 10^{-5}$, or $3.0 \times 10^{9} \mathrm{~Bq}\left(8.1 \times 10^{-2} \mathrm{Ci}\right)$.

4.5.6.2 Discussion of Integrated Normalized Air Concentration Value (X/Q'). After the radioactive material becomes airborne, it is transported downwind and inhaled by onsite workers or the public. The concentration of this material is reduced, or diluted, as it is being transported due to atmospheric mixing and turbulence. $X / Q^{\prime}\left(s / \mathrm{m}^{3}\right)$ is used to characterize the dilution of the airborne contaminants during atmospheric transport and dispersion. It is equal to the time-integrated normalized air concentration at the receptor. $X / Q^{\prime}$ is a function of the atmospheric conditions (i.e., wind speed, stability class) and the distance to the receptor. 
Bounding $\mathrm{X} / \mathrm{Q}^{\prime}$ values are generated consistent with the methods described in Atmospheric Dispersion Models for Potential Accident Consequence Assessments at Nuclear Power Plants, Regulatory Guide 1.145 (NRC 1982). Since atmospheric conditions fluctuate, a bounding atmospheric condition is determined to be that condition that causes a downwind exposure of airborne contaminants that is exceeded only a small fraction of time because of weather fluctuations. Regulatory Guide 1.145 defines this fraction of exceedance as $0.5 \%$ for each sector or $5 \%$ for the overall Hanford Site. The Hanford Site is broken up into 16 sectors that represent 16 compass directions (i.e., S, SSW, SW, ..., ESE, SE, SSE). X/O' values are generated for weather conditions that result in downwind exposures exceeded only $0.5 \%$ of the time in the maximum sector or $5 \%$ of the time for the overall Site. These $X / Q^{\prime}$ values are also referred to as $99.5 \%$ maximum sector and $95 \%$ overall Site $X / O^{\prime}$ values. The greater of these two values is called the bounding $X / Q^{\prime}$ value and is used to assess the dose consequences for accident scenarios. The bounding $X / Q^{\prime}$ value represents minimum dispersing conditions that result in maximum downwind exposures (i.e., exposures exceeded only a very small fraction of the time). This $X / O^{\prime}$ value will therefore result in very conservative estimates of accident consequences.

The $X / Q^{\prime}$ values in this report were generated using the $\mathrm{GXO}$ computer code, Version 4 (Hey 1995a, 1995b). The meteorological data used by GXO are in the form of joint frequency tables. The joint frequency data are the most recent data available; they are nine-year averaged data (1983-1991) from the Hanford Site meteorology towers. As mentioned above, the X/O' values are generated using the methods described in Regulatory Guide 1.145 for a ground release with no credit taken for plume rise, plume meander, plume depletion, or any other models. This is conservative because all of these models reduce the airborne concentration at the downwind receptor locations.

Because the self-container will be transported anywhere on the Hanford Site, $X / Q^{\prime}$ values for the maximum onsite receptor (assumed to be located $100 \mathrm{~m}$ from the release point) were calculated using the joint frequency data for the 100, 200,300, and 400 Areas, and the highest value was selected. The highest $X / \mathrm{O}^{\prime}$ value of $7.32 \times 10^{-2} \mathrm{~s} / \mathrm{m}^{3}$ occurs for a receptor $100 \mathrm{~m}$ east of the release point in the 100 Area.

The worst case public receptor (i.e., highest $X / Q^{\prime}$ ) will be located in the 300 Area due to the short distances between the potential transport routes and a public receptor. Several 300 Area locations have roads which are accessible to the public. Therefore, it is conservatively assumed for this analysis that the offsite receptor is located $100 \mathrm{~m}$ from the release point in any compass direction. The maximum offsite receptor $X / O^{\prime}$ value is $4.21 \times 10^{-2} \mathrm{~s} / \mathrm{m}^{3}$ for a receptor located $100 \mathrm{~m}$ north of the release point in the 300 Area.

An example GXO input file for the maximum onsite receptor at $100 \mathrm{~m}$ is listed in the Appendix, and the titles of the joint frequency files are listed below.

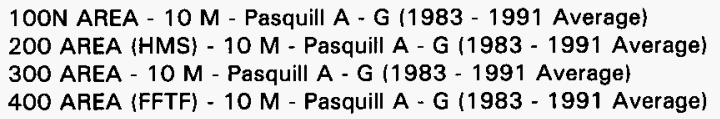

4.5.6.3 Inhalation and Submersion Dose Calculations. Because the GENII computer code Version 1.485 (Napier 1988) is the site standard computer code for environmental release dose calculations, it was used to calculate the inhalation and submersion dose for the maximum onsite receptor and public receptor for a source term consisting of $3.0 \times 10^{9} \mathrm{~Bq}\left(8.1 \times 10^{-2} \mathrm{Ci}\right)$ of ${ }^{137} \mathrm{Cs}$. The GENII input deck for the maximum onsite receptor is listed in Part B, Section 4.7.2.11. The worst case solubility class library was used, which is the most conservative library. The GENII libraries used were as follows: 
GENII Default Parameter Values (28-Mar-90 RAP)

Radionuclide Library - Times $<100$ years (23-July-93 PDR)

External Dose Factors for GENII in person Sv/yr per Bq/n (8-May-90

Worst Case Solubilities, Yearly Dose Increments (23-Jul-93 PDR)

The EDE from GENIt for the inhalation and submersion pathways is $6.1 \times 10^{-4} \mathrm{~Sv}$ $(0.061 \mathrm{rem})$ for the maximum onsite receptor located $100 \mathrm{~m}$ from the release point in the 100 Area. The EDE from GENII is $6.1 \times 10^{4} \mathrm{~Sv}(0.061 \mathrm{rem})$ for the public receptor located $100 \mathrm{~m}$ from the release point in the 300 Area. The inhalation dose contribution to the EDE is based on a 50 year dose commitment period. The X/Q' values from GENII were $7.5 \times 10^{-2} \mathrm{~s} / \mathrm{m}^{3}$ for the maximum onsite receptor in the 100 Area, and $7.4 \times 10^{-2} \mathrm{~s} / \mathrm{m}^{3}$ for the public receptor in the 300 Area. The dose rates calculated by GENII are proportional to the $X / Q^{\prime}$ values. The GXO code calculates the $99.5 \%$ maximum sector and $95 \%$ overall Site $X / Q^{\prime}$ values consistent with Regulatory Guide 1.145 methods, while GENII is inconsistent with Regulatory Guide 1.145 methods. As mentioned in the previous section, the maximum onsite receptor $X / Q^{\prime}$ value from $G X Q$ is $7.32 \times$ $10^{-2} \mathrm{~s} / \mathrm{m}^{3}$ for the maximum onsite receptor in the 100 Area, and is $4.21 \times 10^{-2} \mathrm{~s} / \mathrm{m}^{3}$ for the public receptor in the 300 Area. Therefore, the EDE for the inhalation and submersion pathways is $6.0 \mathrm{x}$ $10^{4} \mathrm{~Sv}(0.060 \mathrm{rem})$ for the maximum onsite receptor at $100 \mathrm{~m}$ from the release point in the 100 Area. This value was obtained by multiplying the GENII dose rate by the ratio of the $G \times O \times / Q^{\prime}$ value to the GENII $X / Q^{\prime}$ value. Similarly, the EDE is $3.5 \times 10^{-4} \mathrm{~Sv}(0.035 \mathrm{rem})$ for the public receptor in the 300 Area.

The Gaussian equation, along with the parameters used to calculate the atmospheric dispersion during plume transport, are only valid for distances of $100 \mathrm{~m}$ or greater. In order to compensate for the fact that the onsite dose is calculated at a source-to-receptor distance of $100 \mathrm{~m}$, this maximum onsite receptor dose at $100 \mathrm{~m}$ from the 100 Area $\left(6.0 \times 10^{-4} \mathrm{~Sv}\right)$ is multiplied by a factor of thirty to obtain the dose to the worker at $1 \mathrm{~m}$ in accordance with IAEA (1990). The dose to the worker is then $0.018 \mathrm{~Sv}(1.8 \mathrm{rem})$. Table B4-3 summarizes the dose to the worker and the public for the fire scenario.

Table B4-3. Whole Body Dose, Sv EDE (rem EDE), for the Hanford Site Worker and the Public.

\begin{tabular}{|c|c|c|}
\hline Scenario & Worker $^{\mathrm{a}}$ & Public $^{\mathrm{b}}$ \\
\hline Fire & $0.018(1.8)$ & $3.5 \mathrm{E}-4(0.035)$ \\
\hline
\end{tabular}

Note: $100 \mathrm{rem}=1 \mathrm{~Sv}$

"Worker located $1 \mathrm{~m}$ from the package.

'Maximum public receptor located $100 \mathrm{~m} \mathrm{~N}$ of the 300 Area.

4.5.6.4 Ingestion Dose for Offsite Receptor. The other potential internal exposure pathway for the offsite receptor is the ingestion pathway. Exposure through the ingestion pathway occurs when radioactive materials that have been deposited offsite during passage of the plume are ingested either by eating crops grown in, or animals raised on, contaminated soil, or through drinking contaminated water. There are the U.S. Department of Energy (DOE); DOE, Richland Operations Office (RL); state; and federal programs in place to prevent ingestion of contaminated food in the event of an accident (DOE-RL 1994, WSDOH 1993, WS 1994, EPA 1992). The primary determinant of exposure from the ingestion pathway is the effectiveness of public health measures (i.e., interdiction) rather than the severity of the accident itself. The ingestion pathway, if it occurs, is a slow-to-develop pathway and is not considered an immediate threat to an exposed population in the same sense as airborne plume exposures. 
The ground shine pathway is an additional potential external exposure pathway for the offsite receptor. Ground shine refers to the external dose received by a person standing on ground contaminated by radioactive materials deposited during passage of the airborne radioactive plume. Similar to the ingestion pathway, the primary determinant of exposure from the ground shine pathway is the effectiveness of public health measures (i.e., interdiction) rather than the severity of the accident itself. The ground shine pathway is a slow-to-develop pathway and is not considered an immediate threat to an exposed population in the same sense as airborne plume exposures.

Because of the large radioactive inventory contained in the self-container, it is argued that in the event of an accident scenario that results in the release of this inventory, interdictive measures (DOE-RL 1994, WSDOH 1993, WS 1994, EPA 1992) would be taken to prevent ingestion of contaminated food, and exposure through the ground shine pathway. Therefore, the ingestion and ground shine pathway doses were not calculated in this report.

\subsubsection{Dose Due to $\beta$-Particle Emitter Skin Contamination}

In the IAEA guide, it is assumed that $1 \%$ of the package contents are spread over an area of $1 \mathrm{~m}^{2}$ and handling of debris results in contamination of the hands to $10 \%$ of this level. It is further assumed that the worker is not wearing gloves but that he recognizes the possibility of contamination and washes his hands within five hours. The effective dose equivalent to the skin received by the individual is estimated from a graph provided in the IAEA guide.

The IAEA scenario for the uptake of activity due to ingestion of the material assumes that the person ingests all of the contamination from $10 \mathrm{~cm}^{2}$ of skin over a 24 hour period. Since the dose per unit uptake via inhalation is generally the same order or larger than that via ingestion, the inhalation pathway will normally be limiting for internal contamination due to beta-ray emitters. In particular, if the skin contamination dose is much larger than the inhalation dose, the ingestion pathway is not considered.

Both these pathways are ordinarily neglected when calculating the dose consequences from an onsite transportation accident. The transportation workers are trained in the appropriate response to protect themselves from experiencing unnecessary radiation exposure, including preventing skin contamination and ingestion.

\subsubsection{Submersion Dose Due to Gaseous Vapor}

This exposure pathway is caused by submersion in a cloud of gaseous isotopes that are not taken into the body. A rapid release of $100 \%$ of the package contents is assumed. The IAEA guide concentrates entirely on releases within confined structures. No guidance is given for outside releases.

There are no gaseous vapors present in the packages; therefore, this exposure pathway is not applicable.

\subsubsection{Special Considerations}

Alpha particle emitters are not of significance in the material considered in this report. The alpha particle emitters are of a low concentration, and their effect will be through the mechanism of inhalation, which has already been considered. Therefore, they are not addressed separately in this report. There are no radon isotopes present in the fuel; therefore, radon is not addressed in this report. 
Excepted quantities of fissile material may be shipped in the self-container and several of these emit neutrons through $\{$ alpha, $\mathrm{n}$ \} and spontaneous fission reactions. However, the neutron source term is low enough that the neutron dose is negligible $(<1 \%)$ compared to the dose from the gamma emitters. Therefore, neutrons are not considered separately in this report.

Bremsstrahlung has been included in the consideration of photon effects, and the effects of short-lived daughter products have been included in all of the calculations. Where these isotopes are significant they are assumed to be in equilibrium with their longer-lived parent isotopes.

\subsubsection{References}

49 CFR 173, 1995, "Shippers--General Requirements for Shipments and Packagings," Code of Federal Regulations, as amended.

DOE, 1994, Airborne Release Fractions/Rates and Respirable Fractions for Nonreactor Nuclear Facilities, DOE-HDBK-3010-94, U.S. Department of Energy, Washington, D. C.

Hey, B. E., 1995a, GXO 4.0 Program Users' Guide, WHC-SD-GN-SWD-30002, Rev. 1, Westinghouse Hanford Company, Richland, Washington.

Hey, B. E., 1995b, GXO 4.O Program Verification and Validation, WHC-SD-GN-SWD-30003, Rev. 1, Westinghouse Hanford Company, Richland, Washington.

HNF-PRO-154, Responsibilities and Procedures for All Hazardous Material Shipments, Fluor Daniel Hanford, Inc., Richland, Washington.

IAEA, 1990, Explanatory Material for the IAEA Regulations for the Safe Transport of Radioactive Material, Safety Series No. 7, Second Edition (As Amended 1990), International Atomic Energy Agency, Vienna, Austria.

Napier, B. A., et al., December 1988, GENII - The Hanford Environmental Radiation Dosimetry Software System, PNL-6584, Pacific Northwest Laboratory, Richland, Washington.

NRC, 1982, Atmospheric Dispersion Models for Potential Accident Consequence Assessments at Nuclear Power Plants, Regulatory Guide 1.145, U.S. Nuclear Regulatory Commission, Washington, D.C. 


\subsubsection{Appendix}

\subsubsection{GXO Input File.}

\section{GXo Ineut for 300 Area}

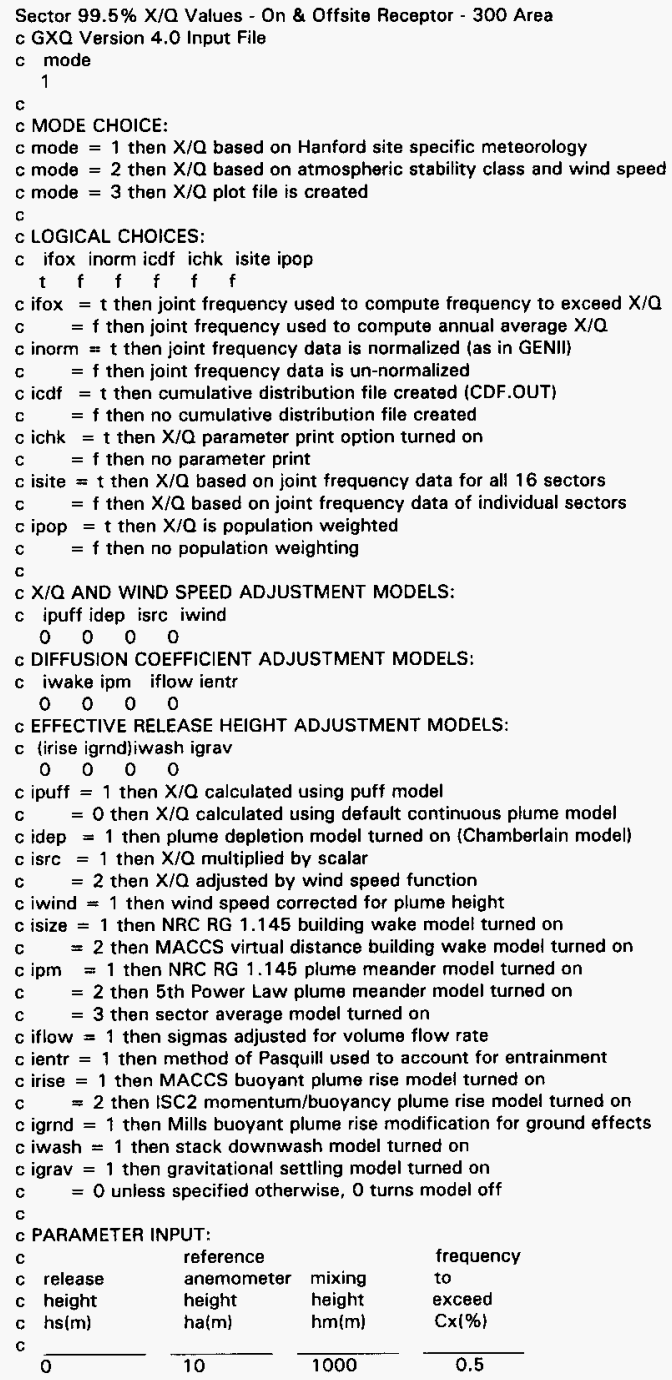


HNF-3341 Rev. 0

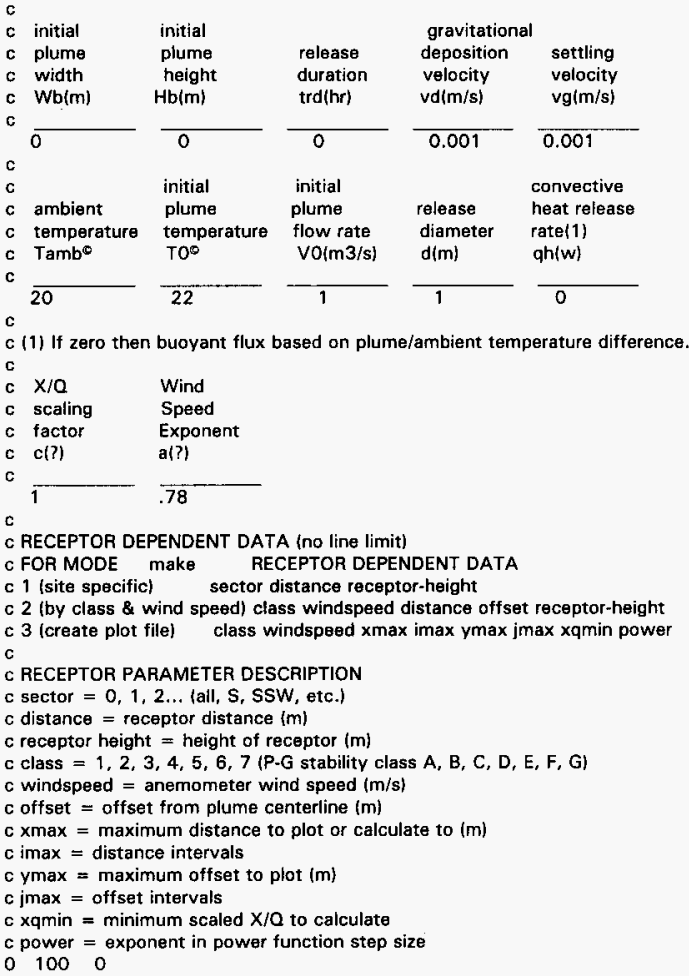


HNF-3341 Rev. 0

\subsubsection{GENII Input Files.}

\section{GENIII Input for Onsite Receptor in 300 Area}

\#\#\#\#\#\#\#\#\#\#\#\#\#\#\#\#\#\#\#\#\#\#\#\# Program GENII Input File \#\#\#\#\#\#\#\#\#\#\#8 Jul 88 \#\#\#\#

Title: Self-Container - Inhalation \& Submersion

$$
\text { ISAMPLIG-AIR.AC Created on 01-22-1990 at 07:30 }
$$

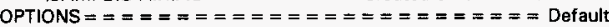

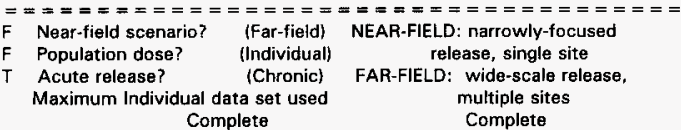

TRANSPORT OPTIONS $==========$ Section EXPOSURE PATHWAY OPTIONS $=====$ Section

$T$ Air Transport 1 F Finite plume, external 5

F Surface Water Transport 2 T Infinite plume, external 5

F Biotic Transport (near-field) 3,4 F Ground, external 5

F Waste Form Degradation (near) 3,4 F Recreation, external 5 $T$ Inhalation uptake $\quad \mathbf{5 , 6}$

REPORT OPTIONS $====== \pm=== \pm========$ F Drinking water ingestion 7,8

$T$ Report AEDE only $\quad F$ Aquatic foods ingestion 7,8

F Report by radionuclide F Terrestrial foods ingestion 7,9

F Report by exposure pathway F Animal product ingestion 7,10

F Debug report on screen $\quad F$ Inadvertent soil ingestion

\section{INVENTORY \#\#\#\#\#\#\#\#\#\#\#\#\#\#\#\#\#\#\#\#\#\#\#\#\#\#\#\#\#\#\#\#\#\#\#\#\#\#\#\#\#\#\#\#\#\#\#\#\#\#\#\#\#\#\#\#\#\#\#\#\#\#\#\#\#\#\#\#}

4 Inventory input activity units: $(1-\mathrm{pCi} 2-\mathrm{uCi} \quad 3-\mathrm{mCi} \quad 4-\mathrm{Ci} \quad 5-\mathrm{Bq})$

0 Surface soil source units $(1-\mathrm{m} 2 \quad 2-\mathrm{m} 3 \quad 3-\mathrm{kg})$

Equilibrium question goes here

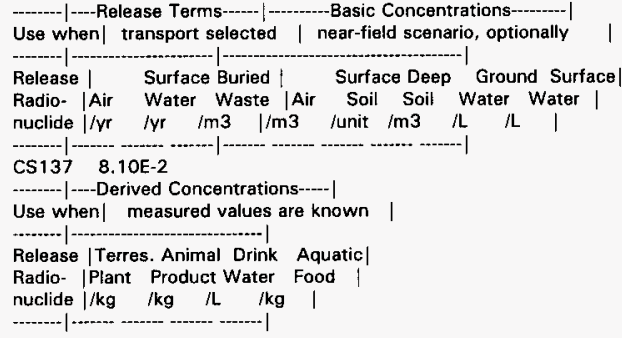

TIME $\# \# \# \# \# \# \# \# \# \# \# \# \# \# \# \# \# \# \# \# \# \# \# \# \# \# \# \# \# \# \# \# \# \# \# \# \# \# \# \# \# \# \# \# \# \# \# \# \# \# \# \# \# \# \# \# \# \# \# \# \# \# \# \# \# \# \# \# \# \# \# \#$

1 Intake ends after (yr)

50 Dose calc. ends after $(\mathrm{yr})$

1 Release ends after $(y r)$

0 No. of years of air deposition prior to the intake period

- No. of years of irrigation water deposition prior to the intake period

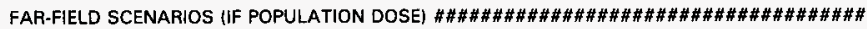

o Definition option: 1-Use population grid in file POP.IN

2-Use total entered on this line

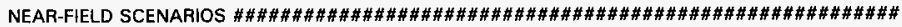

Prior to the beginning of the intake period: (yr)

When was the inventory disposed? (Package degradation starts)

When was LOIC? (Biotic transport starts)

Fraction of roots in upper soil (top $15 \mathrm{~cm}$ )

Fraction of roots in deep soil

Manual redistribution: deep soil/surface soil dilution factor 
$0 \quad$ Source area for external dose modification factor $(\mathrm{m} 2)$

TRANSPORT \#\#\#\#\#\#\#\#\#\#\#\#\#\#\#\#\#\#\#\#\#\#\#\#\#\#\#\#\#\#\#\#\#\#\#\#\#\#\#\#\#\#\#\#\#\#\#\#\#\#\#\#\#\#\#\#\#\#\#\#\#\#\#\#\#\#\#

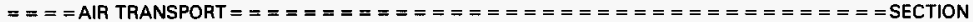

$1====$

3 Option: 1-Use chi/O or PM value |F Stack release (T/F)

2-Select Mi dist \& dir 10 Stack height (m)

3-Specify Ml dist \& dir $\mid 0 \quad$ Stack flow $(\mathrm{m} 3 / \mathrm{sec})$

1 Chi/O or PM value $\quad 0$ Stack radius (m)

14 Ml sector index $(1=\mathrm{S}) \quad$ Effluent temp.

100. MI distance from release point $(\mathrm{m}) \mid 0 \quad$ Building $x$-section $(\mathrm{m} 2)$

$T \quad$ Use jf data, (T/F) else chi/O grid $\mid O \quad$ Building height $(\mathrm{m})$

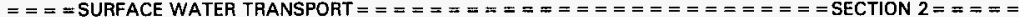

Mixing ratio model: 0 -use value, 1-river, 2-lake

Mixing ratio, dimensionless

Average river flow rate for: $M I X F L G=0(\mathrm{~m} 3 / \mathrm{s}), M I X F L G=1,2(\mathrm{~m} / \mathrm{s})$,

Transit time to irrigation withdrawl location (hr)

If mixing ratio model $>0$ :

Rate of effluent discharge to receiving water body $(\mathrm{m} 3 / \mathrm{s})$

Longshore distance from release point to usage location ( $m$ )

Offshore distance to the water intake ( $\mathrm{m}$ )

Average water depth in surface water body (m)

Average river width (m), MIXFLG $=1$ only

Depth of effluent discharge point to surface water $(\mathrm{m})$, lake only

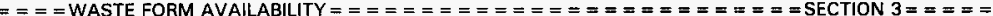

Waste form/package half life, (yr)

Waste thickness, (m)

Depth of soil overburden, $m$

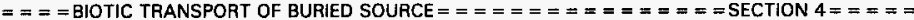

Consider during inventory decay/buildup period (T/F)?

Consider during intake period (T/F)? | 1-Arid non agricultural

Pre-Intake site condition. 2-Humid non agricultural

3-Agricultura

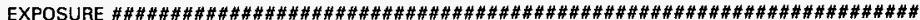

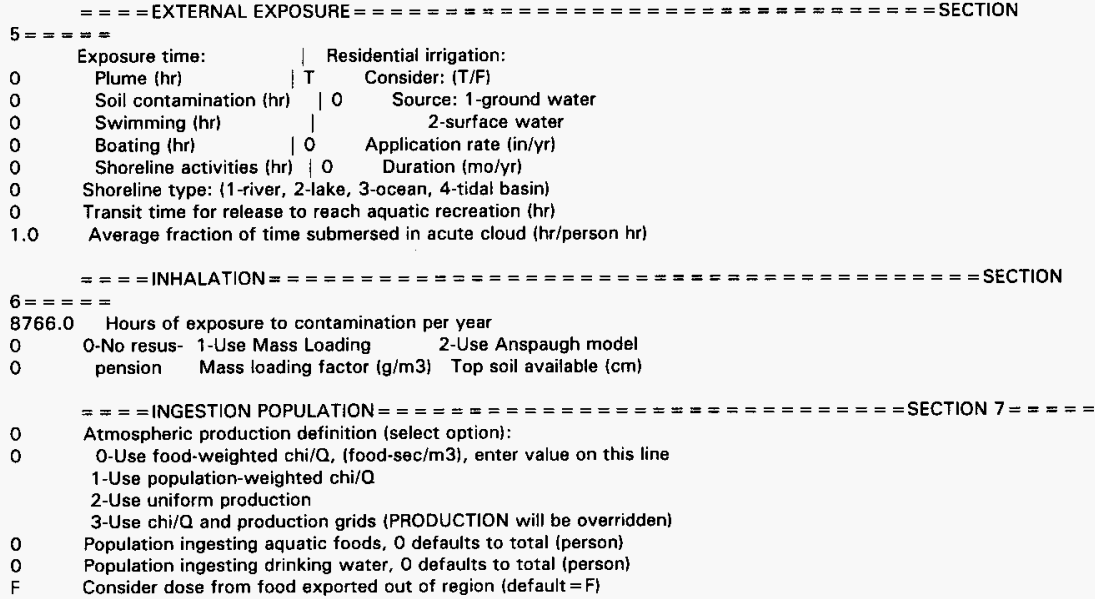

Note below: $S^{*}$ or Source: 0-none, 1-ground water, 2-surface water 3-Derived concentration entered above 
HNF-3341 Rev. 0

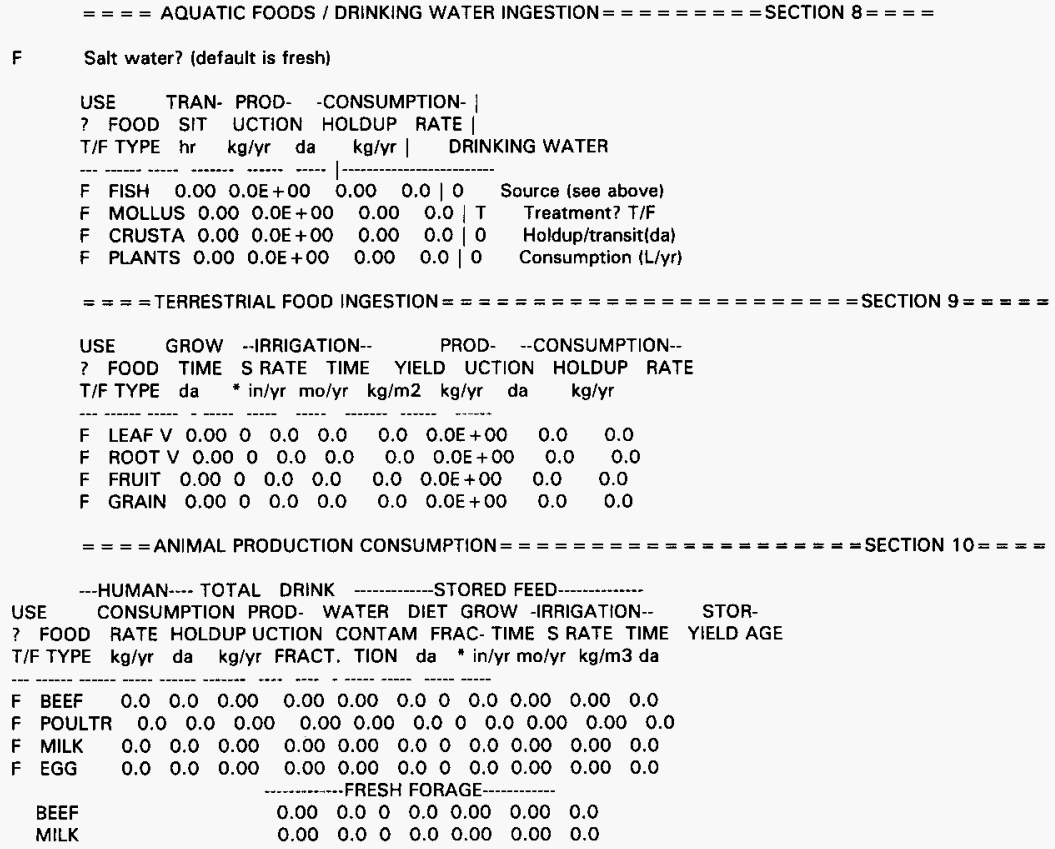




\section{CHECKLIST FOR CHECKING OF ANALYSIS/CALCULATIONS}

Document Number/Revision:SD-RE-SAP-025 Rev 3

Document Title: Dose Consequence Analysis for the Decontaminated Equipment SelfContainer (Section B 4.5)

Yes No N/A

[x] [ ] [ ] Problem completely defined.

[x] [] [ ] Appropriate analytical method used.

[x] [ ] II Necessary assumptions are appropriate and explicitly stated.

[x] [ ] [ ] Computer codes and data files documented.

[x] [ ] [ ] Data used in calculations explicitly stated in document.

[ ] [ ] [x] Sources of non-standard formula/data are referenced and the correctness of the reference verified.

[x] I ] [ ] Data checked for consistency with original source information as applicable.

[x] [ ] [ ] Mathematical derivations checked including dimensional consistency of results.

[x] [ ] [ ] Models appropriate and used within range of validity or use outside range of established validity justified.

[x] [ ] [ ] Hand calculations checked for errors.

[x] [ ] I ] Code run streams correct and consistent with analysis documentation.

[x] [1 [ ] Code output consistent with input and with results reported in analysis documentation.

[x] (1) [ ] Acceptability limits on analytical results applicable and supported. Limits checked against sources.

[x] [1 [] Safety Margins consistent with good engineering practices.

[x] [ ] [1 Conclusions consistent with analytical results and applicable limits.

[x] 1] [1 Results and conctusions address all points required in the problem statement.

I have checked the analysis/calculation and it is complete and accurate to the best of my knowledge.

Engineer/Checker J.G. McEadden Do De Fadelen_6/8/98

NOTE: Any hand calculations, notes or summaries generated as part of this check should be signed, dated, and attached to this checklist. Material should be labeled and recorded so that it is intelligible to a technically qualified third party. 


\section{HEDOP REVIEW CHECKLIST \\ for \\ Radiological and Nonradiological Release Calculations}

Document reviewed (include title or description of calculation, document. number, author, and date, as applicable):

Document: "Dose Consequence Analysis for the Decontaminated Equipment SelfContainer SARP." by A. V. Savino, dated June 2, 1998.

Submitted by: A. V. Savino

Date Submitted: $6 / 2 / 98$

Scope of Review: Section 4.5 "Summary of Dose Consequence Results"

YES NON N/A

[X] [ ] [ ] 1. A detailed technical review and approval of the environmental transport and dose calculation portion of the analysis has been performed and documented.

[ ] [ ] $[\mathrm{X}]$ 2. Detailed technical review(s) and approva $7(\mathrm{~s})$ of scenario and release determinations have been performed and documented.

$\left[\begin{array}{llll}] & {[X]} & {[}\end{array}\right]$ 3. HEDOP-approved code(s) were used.

[]$\left[{ }^{2}[X]\right.$ 4. Receptor locations were selected according to HEDOP recommendations.

[X] [ ] [ ] 5. Al] applicable environmental pathways and code options

[x] were included and are appropriate for the calculations.

$[X] \quad[\quad] \quad[$ ] 6 . Hanford site data were used

$[X] \quad\left[\begin{array}{lll}] & {[}\end{array}\right]$ 7. Model adjustments external to the computer program were justified and performed correctly.

$[X] \quad[$ ] [ ] 8. The analys is is consistent with HEDOP reconnendations.

$[X] \quad[] \quad 9$. Supporting notes. calculations, comments, comment resolutions, or other information is attached. (Use the "Page $I$ of $X$ " page numbering format and sign and date each added page.)

[X] [ ] 10. Approval is granted on behalf of the Hanford Environmental Dose Overview Panel.

* All "NO" responses must be explained and use of nonstandard methods justified.

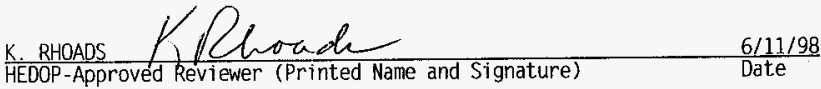

COMMENTS (add additional signed and dated pages if necessary):

Item 3: GXQ v. 4.0 used for air transport calculations; GENII results are included for comparison. 


\subsection{SHIELDING EVALUATION}

\subsection{INTRODUCTION}

By its nature, the self-container will vary in size, interior radionuclide content, and will vary in its ability to self-shield the interior source. Because of the variability in the container and source characteristics, a shielding analysis has not been performed for the self container. Procedures for transporting the self container will be based on meeting the operational dose rate requirements stipulated below.

\subsection{ACCEPTANCE CRITERIA}

The radiation dose on the external surface of the self container shall not exceed $10 \mathrm{mSv} / \mathrm{h}$ $(1,000 \mathrm{mrem} / \mathrm{h})$. The radiation dose at $2 \mathrm{~m}$ from any point on the self container shall not exceed $0.1 \mathrm{mSv} / \mathrm{h}(10 \mathrm{mrem} / \mathrm{h})$. At the driver location, the dose rate shall not exceed $0.02 \mathrm{mSv} / \mathrm{h}$ $(2 \mathrm{mrem} / \mathrm{h})$ if the driver is not a trained radiological worker, or $0.05 \mathrm{mSv} / \mathrm{h}(5 \mathrm{mrem} / \mathrm{h})$ if the driver is a radiological worker.

\subsection{SHIELDING SUMMARY}

Radiation measurement shall be performed to verify compliance with the acceptance criteria. Because of the probable extended size of the source within the self container it is possible that the dose rate will not fall rapidly with distance from the surface. Therefore, when dose rate measurements are performed to insure that the self container meets the acceptance criteria, special attention should be given to points $2 \mathrm{~m}$ from the container surface and at the driver location. 
HNF-3341 Rev. 0

This page intentionally left blank.

B5-2 
HNF-3341 Rev. 0

\subsection{CRITICALITY EVALUATION}

The self container is only authorized for shipment of fissile excepted material. Fissile excepted material consists of less than $15 \mathrm{~g}$ of the fissile radionuclides ${ }^{233} \mathrm{U},{ }^{235} \mathrm{U},{ }^{239} \mathrm{Pu}$, and ${ }^{241} \mathrm{Pu}$ as defined in 49 CFR $173.453(a)$. Therefore, no criticality analysis is required.

\subsection{REFERENCE}

49 CFR 173, 1995, "Shippers--General Requirements for Shipments and Packagings," Code of Federal Regulations, as amended. 
HNF-3341 Rev. 0

This page intentionally left blank.

B6-2 
HNF-3341 Rev. 0

\subsection{STRUCTURAL EVALUATION}

\subsection{INTRODUCTION}

Self-containers are defined, in structural terms, as packages which have sufficient structural integrity to retain its contents under NTC. The objective of this evaluation is to demonstrate that packages defined under this SARP as self-containers are safe for transport and will maintain structural integrity under NTC. Accident conditions for these packages are evaluated in Part B, Section 3.0 (Radiological Risk).

\subsection{STRUCTURAL EVALUATION OF PACKAGE}

Packages evaluated in this SARP are for transport only within the boundaries of the Hanford Site under the auspicious of the Onsite Transportation Safety Program. Self-containers transported under this SARP are required, as a minimum, to maintain structural integrity when evaluated to the performance tests for NTC defined in this section.

\subsubsection{Structural Design and Features}

Packages transported under this SARP vary in size, shape, weight, and materials of construction. Consequently, for these evaluations the package size and shape are enveloped as either a $12 \mathrm{~m}(40 \mathrm{ft})$ long, $2.5 \mathrm{~m}(8 \mathrm{ft})$ wide, and $3 \mathrm{~m}(10 \mathrm{ft})$ high cuboid or a $2.5 \mathrm{~m}(8 \mathrm{ft})$ diameter by $12 \mathrm{~m}$ (40 long) cylinder. The weight of the package is limited to a weight of $22,680 \mathrm{~kg}$ $(50,000 \mathrm{lb})$.

Packages transported under this SARP shall have sufficient structural integrity to support its own weight and sustain the NTC loadings without fracturing, rupturing, fragmenting or release of material. Packages may be constructed of metals, plastics, concrete, or wood and may have been fabricated by welding, gluing, bolting, nailing, forming or strapping.

\subsubsection{Mechanical Properties of Materials}

The materials of construction for self-container packages can vary from stainless steel for vessels and aluminum for roll-out platform ladders to concrete slabs and plastic vessels. As a consequence, a wide array of materials are evaluated for the various NTC performance test requirements defined in this section. Acceptable materials of outer construction for self-container packages are any steel, any metal, concrete (either reinforced or unreinforced), plastic, wood or composite material with sufficient strength to maintain structural integrity under NTC.

For this evaluation to envelope material properties, the room temperature values of the most conservative published mechanical properties of the least enhanced alloy is used. As an example for aluminum, the mechanical properties for 1060 aluminum, based on American Society for Testing and Materials (ASTM) published properties are used for all aluminums. In the case of steel the mechanical properties for ASTM A611 Grade A cold rolled steel sheet.

\subsubsection{Chemical and Galvanic Reactions}

Based on the variety of materials and material combinations from which a self-container package can be manufactured and previous environment to which it was exposed in most cases is unknown, chemical and galvanic reaction of the material or materials must be assumed to have 
affected the structural properties of the material. However, the radioactive contents were deposited as a result of the use of the equipment. Therefore, it is unlikely there is a significant chemical or galvanic problem that would affect one-time shipment.

\subsubsection{Size of Package and Cavity}

Self-containers will be of various shapes and sizes enveloped by a $12 \mathrm{~m}$ (40 ft) long by $2.5 \mathrm{~m}(8 \mathrm{ft})$ wide by $3 \mathrm{~m}(10 \mathrm{ft}$ ) high cuboid and a $12 \mathrm{~m}(40 \mathrm{ft})$ long by $2.5 \mathrm{~m}(8 \mathrm{ft})$ diameter cylinder. The package weight for shipment under this SARP is $22,680 \mathrm{~kg}(50,000 \mathrm{lb})$. Package parameters specified above are for packages which can be transported by standard conveyances. Oversized packages having geometries and/or weights which exceed the above specified parameters may be transported under this SARP under the following conditions:

1. The package meets all requirement of Part B, Section 7.2.

2. The tiedown system conforms to all requirements specified in Part B, Section $\mathbf{1 0 . 2}$ for oversized packages.

3. An authorized representative of Waste Management Federal Services, Inc., Northwest Operations (WMNW) Transportation Logistics shall approve the tiedown and blocking configuration.

\subsubsection{Weights and Center of Gravity}

The gross weight of a typical self-container package to be transported on a standard trailer is limited to $22,680 \mathrm{~kg}(50,000 \mathrm{lb})$. For conservatism in evaluation, the center of gravity of the self-container package is assumed to be $\%$ the distance from the bottom to the top of the package in the orientation that it is transported. In the longitudinal and lateral axes, the center of gravity of the package is assumed to be at the geometric center of the package.

\subsubsection{Tamper-Indicating Feature}

Since the self-container package itself is the package and contents, no tamper-indicating features are required.

\subsubsection{Positive Closure}

For self-container packages, only those having an internal cavity are required to have a positive closure. Depending upon the material of construction and configuration of the package positive closure shall be accomplished by closure weight, bolting, gluing, welding, nailing, or strapping.

\subsubsection{Lifting and Tiedown Devices}

Lifting of the self-container package shall be performed in accordance with the Hanford Site Hoisting and Rigging Manual (RL 1993) requirements. Whenever lifting points with known and marked ratings are provided on the unit they shall be used for lifting and handling of the package. If no lifting points with known rating are provided, the package will be lifted and handled with slings and shackles in accordance with the Hanford Site Hoisting and Rigging Manual (RL 1993) requirements. Components or device on the package shall be used as a tiedown attachment or 
point unless it is clear defined as such on the package or has been demonstrated to sustain a load of 3 times the weight of the package in the direction of loading without yielding the material.

\subsubsection{Brittle Fracture}

Materials on load bearing component of the package shall not be susceptible to brittle fracture at an ambient temperature of $-33^{\circ} \mathrm{C}\left(-27^{\circ} \mathrm{F}\right)$. However in this case, because of variability of the materials the allowable ambient temperature for transport is limited to $4{ }^{\circ} \mathrm{C}\left(40{ }^{\circ} \mathrm{F}\right)$. Transporting below this limit requires that the load bearing material be demonstrated to be capable of sustaining load without fracture at temperatures below the specified ambient temperature (i.e., stainless steel).

\subsection{NORMAL TRANSFER CONDITIONS}

\subsubsection{Conditions to be Evaluated}

Defined in this section are the packaging evaluation requirements for onsite conditions to demonstrate the package meets the intent of the regulations. These performance requirements are based on the required performance tests defined in the DOT regulations

\subsubsection{Hot and Cold Conditions.}

7.3.1.1.1 Heat. Evaluate package and payload performance for extreme ambient temperature of $46^{\circ} \mathrm{C}\left(115^{\circ} \mathrm{F}\right)$ in still air, with decay heat and solar insolation for a 12-hour day based on the following.

Table B7-1. Solar Heat Loads.

\begin{tabular}{|c|c|}
\hline Form and location of surface & Insolation for 12 hours per day \\
\hline $\begin{array}{c}\text { Flat surface transported horizontally: } \\
\text { Base } \\
\text { Other surfaces }\end{array}$ & $\begin{array}{c}\text { None } \\
\text { Flat surface not transported horizontally: } \\
\text { Each surface }\end{array}$ \\
\hline \begin{tabular}{c} 
Curved surfaces \\
\hline
\end{tabular} & $162 \mathrm{cal} / \mathrm{cm}^{2}\left(597 \mathrm{BTU} / \mathrm{ft}^{2}\right)$ \\
\hline
\end{tabular}

7.3.1.1.2 Cold. Evaluate package and payload performance for extreme ambient temperature of $-33^{\circ} \mathrm{C}\left(-27^{\circ} \mathrm{F}\right)$ in still air and in the shade.

\subsubsection{Reduced and Increased External Pressure.}

7.3.1.2.1 Reduced External Pressure. The self-container packages are not leak-tight, consequently NTC pressure changes do not affect NTC performance of the package and is not evaluated in this SARP. 
7.3.1.2.2 Increased External Pressure. The self-container packages are not leak-tight, consequently NTC pressure changes do not affect NTC performance of the package and is not evaluated in this SARP.

7.3.1.3 Vibration. Self-container packages are one-way shipments over short distance fless than 50 miles). Also the vibrational frequencies normally incident to transport on the package are in the range of 2 to $5 \mathrm{~Hz}$ (ANSI 1980). Since transport of the package is only to the destination and not used continuously the number of vibrational loading cycles that the package is subjected to is low (less than 10,000 ). Based on these factors the package is not susceptible to vibrational loading during NTC. Consequently, fatigue and vibrational performance is not evaluated in this SARP.

7.3.1.4 Water Spray. Evaluate the self-container package performance for a simulated rainfall of $1.5 \mathrm{~cm}(0.6 \mathrm{in.})$ per hour for at least 1 hour.

7.3.1.5 Inertial Loading. No in-transient load transfers are allowed under this SARP.

Consequently, the self-container package shall maintain structural integrity during decontamination, handling, loading, and unloading operations. Also the package shall be capable of sustaining conveyance induced inertial loads of $0.4 \mathrm{~g}$ in longitudinal and lateral directions and $0.2 \mathrm{~g}$ in the vertical direction of the conveyance. This requirement is based upon research and testing conducted by the Canadian Council of Motor Transportation Administration ([CCMTA] 1997).

7.3.1.6 Compression. Compression evaluation is not applicable to transport of the self-container package, since no stacking is allowed. Subsequently, this is not evaluated in this SARP.

7.3.1.7 Penetration. The self-container package performance is evaluated for a vertical steel cylinder with a $3.2 \mathrm{~cm}$ (1.25 in.) diameter hemispherical end and $6 \mathrm{~kg}(13 \mathrm{lb})$ of mass, dropping from a height of $1 \mathrm{~m}(3 \mathrm{ft}$ ) onto the lid. The cylinder is assumed to strike the drum's exposed surface in the region most vulnerable to puncture. The long axis of the cylinder is assumed to be perpendicular to the package surface.

\subsubsection{Acceptance Criteria}

The minimum overall acceptance criteria for normal transport of self-container packages is that the package not fracture, rupture, fragment or otherwise release material during transport. Consequently, the package must remain intact and on the conveyance under all NTC. Lifting and penetration performance acceptance criteria shall be based on yield strength of the material.

\subsubsection{Environmental Heating}

Based on the allowable source terms specified in this SARP, the radiological heat loads are negligible. Consequently, the exterior temperature of self-container packages will not exceed ambient air temperatures in the shade. As shown in the thermal evaluations (Part B, Section 8.0), the maximum exterior steady state enveloping temperature of the self-container package is $91{ }^{\circ} \mathrm{C}$ $\left(196{ }^{\circ} \mathrm{F}\right)$ with insolation. This temperature is well within the range of allowable material properties for common materials of construction.

\subsubsection{Maximum Thermal and Pressure Stresses}

Self-container packages are not hermetically sealed. Consequently, increased and reduced pressure due to internal or external heating is not a concern. Also, the relative difference in the thermal coefficient of expansion between common materials of construction are not significant at the temperature range determined above. 


\subsubsection{Inertial Loading}

A prerequisite for a self-container package is that it must sufficient structural integrity to support is own weight when placed on the conveyance. Also, it must sufficient structural integrity that it will not fragment, fracture, rupture or release material during decontamination, disassembly, handling, loading and unloading operations. These operational loads imposed on the self-container are higher than the normal transportation loads specified by the CCMTA. As an example, depending upon the operator, normal (non-critical) lifting operations subject equipment and components to inertial loads as high as 1.25 times their normal weight or 1.25 gs. Also, normal disassembly and handling operations, such extracting jammed components, can subject equipment and components to inertial loads well above $0.4 \mathrm{~g}$. Consequently, if the item can sustain the inertial loads from decontamination, disassembly, handling, loading, and unloading operations, then it will sustain the loads induced by the conveyance during normal transport when properly secured.

\subsubsection{Penetration}

The required exterior material thickness to prevent penetration of self-container packages are determined in Part B, Section 7.6. The evaluation shows that a $3.2 \mathrm{~cm}(1.25 \mathrm{in}$.) diameter hemispherical end rod weighing $6 \mathrm{~kg}(13 \mathrm{lb})$ dropped from a height of $1 \mathrm{~m}(3 \mathrm{ft})$ will not penetrate the minimum specified thickness for a given material shown in Table B7-2. Consequently, all exterior surface components of the self-container shall have the required minimum thickness for the exterior surface material of construction or vulnerable area will be protected by a protective shell.

Table B7-2. Minimum Thickness of Materials.

\begin{tabular}{|l|c|}
\hline \multicolumn{1}{|c|}{ Material } & $\begin{array}{c}\text { Minimum thickness } \\
\mathrm{cm}(\text { in.) }\end{array}$ \\
\hline Steel & $0.328(0.129)$ \\
\hline Lead & $0.767(0.302)$ \\
\hline Aluminum & $0.394(0.155)$ \\
\hline Copper & $0.422(0.166)$ \\
\hline Concrete & $0.5(0.2)$ \\
\hline Wood & $0.8(0.3)$ \\
\hline
\end{tabular}

\subsubsection{Structural Evaluation Conclusions}

Based on the structural NTC criteria established in this section and package structural restrictions, the above performance evaluations show that self-container packages will meet the NTC.

\subsection{ACCIDENT CONDITIONS}

The self-container is not assumed to provide containment in an accident. Consequently, accident conditions are evaluated in Part B, Section $\mathbf{3 . 0}$ of this SARP. 
HNF-3341 Rev. 0

\subsection{REFERENCES}

ANSI, 1980, American National Standard Design Basis for Resistance to Shock and Vibration of Radioactive Material Packages Greater than One Ton in Truck Transport, Draft, ANSI N14.23, American National Standards Institute, New York, New York.

ССMTA, 1997, A Uniform Cargo Securement Standard for Highway Transport Vehicles, Canadian Council of Motor Transport Administrators, Ottawa, Canada.

RL, 1993, Hanford Site Hoisting and Rigging Manual, DOE-RL-92-36, U.S. Department of Energy, Richland Operations Office, Richland, Washington. 
HNF-3341 Rev. 0

\subsection{APPENDICES}

\subsubsection{Penetration Evaluation}

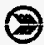

ENGINEERING SAFETY EVALUATION

mmNw

Subject:_Self-Container Penetration Exaluation

Page 1 of 3

Preparer:S.S. Shiraga _ Date 9/02/98

Checker: S. N. Huang An Ttuang Date_9/10/98

Section Chief:B.J. Smith $x / 2$ Date

\subsection{OBJECTIVE}

The objective of this evaluation is to determine the minimum thickness of various materials to prevent penetration of a Decontaminated Equipment Self Container package.

\subsection{REFERENCES}

Rinehart, J. S., and Pearson, J., 1954, Behovior of Metals Under Impu/sive Loads, American Society of Metals, Cleveland, Ohio.

Faupel, J. H. \& Fisher, F. E., 1981, Engineering Design, Second Edition, John Wiley \& Sons, New York, New York.

\subsection{ASSUMPTIONS, RESULTS, AND CONCLUSIONS}

In this evaluation, the Decontaminated Equipment Self Container package is assumed to be manufactured from common materials of sufficient structural integrity such as a solid metal, concrete, or wood to prevent penetration of a $6 \mathrm{~kg}(13 \mathrm{lb})$ bar dropping from $1 \mathrm{~m}(3 \mathrm{ft})$. The evaluation shows that the bar will not penetrate the following materials having the minimum thickness specified. The results are summarized in the following table:

Material versus Minimum Thickness

\begin{tabular}{|c|c|}
\multicolumn{2}{c|}{ Material versus Minimum Thickness } \\
\hline Material & Minimum Thickness (in) \\
\hline Steel & 0.129 \\
\hline Lead & 0.302 \\
\hline Copper & 0.166 \\
\hline Aluminum & 0.155 \\
\hline Concrete & 0.2 \\
\hline Wood & 0.3 \\
\hline
\end{tabular}

Materials in the above table having the minimum specified thickness meet the NTC penetration test requirements. 
HNF-3341 Rev. 0

\section{ENGINEERING SAFETY EVALUATION}

Subject: Self-Container Penetration Evaluation

Page 2 of 3

Preparer:_S.S.S. Shirana

Date $9 / 02 / 98$

Checker: S. N. Hueng Ant

Date $9 / 10 / 98$

Section Chief: R. J, Smith

Date $\quad 9 / 10 / 98$

4.0 EVALUATION

\section{Penetration Evaluntion for Self-Containers:}

The penetration test for a normal conditions is a vertical steel cylinder with a $3.2 \mathrm{~cm}$ (11/4in.) diameter hemispherical end and $6 \mathrm{~kg}(13 \mathrm{lb})$ of mass, dropping from a height of $1 \mathrm{~m}$ onto the drum. The cylinder is assumed to strike the drum'exposed surface in the region most vulnerable to puncture. The long axis of the cylinder is assumed to be perpendicular to the package surface. The package must not be punctured by the cylinder.

Penetration of Metallic Materials:

According to Rhinehart and Pearson (Rhinehart 1954, pg 202) at low velocities, the force that act on the penetration bar during entry into a target is proportional to the cross sectional area of the projectile and will be essentially constant during penetration. Under these conditions the volume displaced of the impact crater is given by:

$$
\text { Volkkcon }\left(\frac{1}{2} \cdot \mathrm{M} \cdot \mathrm{v}_{0}^{2}\right)
$$

For a spherical leading edge, the crater depth to which the material fails is given by:

$$
s=\left(\frac{6 \cdot \mathrm{Vol}}{\pi}\right)^{\frac{1}{3}}
$$

Where $s$ is the material failure depth, $v_{0}$ is the striking velocity, $M$ is the mass of the projectile, kon is an empirical constant and equal to the volume of the target material displaced per unit kinetic energy of the bar, and Vol is the volume of the crater.

Height of drop: $\quad \mathbf{h}_{\mathbf{d}}:-1 \cdot \mathrm{m} \quad$ Mass of bar: $\quad \mathbf{M}:=6 \cdot \mathrm{kg} \quad$ Cross-sectional diameter of bar: $\quad \mathrm{d}_{\mathrm{b}}: 3.2-\mathrm{cm}$ Striking velocity of bar: $\quad v_{0}=\sqrt{2 \cdot g \cdot h_{d}} \quad v_{0}=14.53 \cdot \frac{\mathrm{ft}}{\mathrm{sec}}$

Cross-sectional area of bar: $\quad A_{\text {cs }}=\frac{\mathrm{d}_{\mathrm{b}}{ }^{2}}{4}$

Experimentally determined material displacement per unit of energy (Rhinehart 1954, pg 202):

$$
\begin{aligned}
& \text { Steels: } k \operatorname{con} s t=0.2610^{-4} \cdot \frac{\mathrm{in}^{3}}{\mathrm{ft} \cdot \mathrm{lbf}} \quad \text { Lead: } \quad k \operatorname{con} \mathrm{pb}:=3.31 \cdot 10^{-4} \cdot \frac{\mathrm{in}^{3}}{\mathrm{ft} \cdot \mathrm{lbf}} \\
& \text { Copper: } k \operatorname{con} \mathrm{cu}=0.5510^{-4} \cdot \frac{\mathrm{in}^{3}}{\mathrm{f} \cdot \mathrm{lbf}} \quad \text { Aluminum: kcon al } \cdot 0.45 \cdot 10^{4} \cdot \frac{\mathrm{in}^{3}}{\mathrm{ft} \cdot \mathrm{lbf}}
\end{aligned}
$$

MMWW.PE-001/2 
HNF-3341 Rev. O

은

ENGINEERING SAFETY EVALUATION

Subject: Self-Container Penetration Evaluation

Preparer: S. S. Shiraga

Page 3 of 3

Date $9 / 02 / 98$

Section Chief: R. d. Smith $2 / 2$

Date $9 / 10 / 98$

Assuming as a worst case targets are semi-infinite plates, determine penetration of bar into the material.

For steel:

Displaced volume: $V_{s t}:=k_{\text {con }} s t\left(\frac{1}{2} \cdot M \cdot v_{0}^{2}\right) \quad$ Depth of material failure $s_{s t} \cdot\left(\frac{6 \cdot V_{0 l} s t}{x}\right)^{3} s_{s t}=0.129$-in

For lead:
Displaced volume: $\quad V_{\mathrm{pb}}:=k \operatorname{con} \mathrm{pb} \cdot\left(\frac{1}{2} \cdot \mathrm{M} \cdot \mathrm{v}_{\mathrm{o}}{ }^{2}\right) \quad$ Depth of material failure $\mathrm{s} p \mathrm{pb}:=\left(\frac{6 \cdot \mathrm{Vol}_{\mathrm{ob}}}{\pi}\right)^{\frac{1}{3}} \mathrm{~s}_{\mathrm{pb}}=0.302 * \mathrm{i}$

For aluminum:

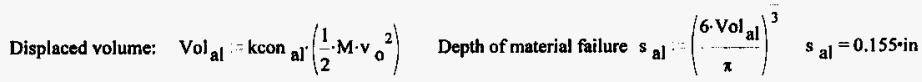

For copper:
Displaced volume: $\quad V_{0 l} \mathrm{cu} \cdot \mathrm{kcon}_{\mathrm{cu}} \cdot\left(\frac{1}{2} \cdot \mathrm{M} \cdot \mathrm{v}_{0}{ }^{2}\right) \quad$ Depth of material failure $\mathrm{s}_{\mathrm{cu}} \cdot-\left(\frac{6 \cdot \mathrm{Vol} \mathrm{cu}}{x}\right)^{\frac{1}{3}} \mathrm{~s}_{\mathrm{cu}}=0.166 \cdot \mathrm{in}$

\section{Penetration of Concrete:}

Empirical equations from (Faupel 1981) for penetration of concrete:

Assume concrete compressive strength of: $\quad f_{c}:=3000 p s i$

Weight of projectile: $\quad W_{p}:=\mathbf{M} \cdot \mathbf{g} \quad W_{p}=13.23 \cdot \mathrm{lbf}$

$$
\mathrm{s}_{\mathrm{con}}=\frac{5.423\left(\frac{\mathrm{W}_{\mathrm{p}}}{\mathrm{lbf}}\right) \cdot\left(\frac{\mathrm{v}_{\mathrm{o}}}{\mathrm{fps}}\right)^{1.33}}{10^{4} \cdot\left(\frac{\mathrm{d}_{\mathrm{b}}}{\mathrm{in}}\right)^{1.8}} \cdot \text { in } \quad \mathrm{s}_{\mathrm{con}}=0.2 \cdot \mathrm{in}
$$

Empirical equation from (Faupel 1981) for penetration of wood: $s$ wood $:=2 \cdot s$ con

$$
s_{\text {wood }}=0.3 \cdot \text { in }
$$

MANW-PE-OO1/2 
Rev. 0

This page intentionally left blank. 
HNF-3341 Rev, 0

\subsection{THERMAL EVALUATION}

\subsection{INTRODUCTION}

The objective of this thermal evaluation is to demonstrate that self-container packages meets NTC exterior surface temperature requirement for onsite transport. Accident conditions for these packages are evaluated in Part B, Section 3.0 (Radiological Risk).

\subsection{THERMAL EVALUATION OF PACKAGE}

\subsubsection{Package Description}

Packages transported under this SARP vary in size, shape, weight, and materials of construction. Consequently, for this evaluation the package size and shape are enveloped as either a $12 \mathrm{~m}(40 \mathrm{ft})$ long, $2.5 \mathrm{~m}(8 \mathrm{ft})$ wide, and $3 \mathrm{~m}(10 \mathrm{ft})$ high cuboid or a $2.5 \mathrm{~m}(8 \mathrm{ft})$ diameter by $12 \mathrm{~m}(40 \mathrm{ft}$ ) long cylinder. The weight of the package is limited to a maximum weight of $22,680 \mathrm{~kg}\langle 50,000 \mathrm{lb}\rangle$. For enveloping thermal heat loads this evaluation assumes the packages are constructed of polished stainless steel with a solar absorptivity of carbon steel.

Packages transported under this SARP shall have no significant internal heat load, sufficient structural integrity to support its own weight and sustain the NTC loadings without fracturing, rupturing, fragmenting, melting, or release of material. Packages may be constructed of metals, plastics, concrete, or wood and may have been fabricated by welding, gluing, bolting, nailing, forming or strapping.

\subsection{NORMAL TRANSPORT CONDITIONS THERMAL EVALUATION}

\subsubsection{Conditions to be Evaluated}

Thermal performance of the self-container packages are assessed for Hanford Site normal transfer conditions in this section. Self-container packages are evaluated for the worst case Hanford Site thermal loading condition of still air ambient temperature of $46^{\circ} \mathrm{C}\left(115^{\circ} \mathrm{F}\right)$ (Fadeff 1992) with decay heat sources with and without insolation.

Under insolation the package and payload performance is evaluated for an extreme ambient temperature of $46^{\circ} \mathrm{C}\left(115^{\circ} \mathrm{F}\right)$ (Fadeff 1992) in still air, with decay heat, and with insolation for a 12-hour day based on Table B8-1. 
Table B8-1. Solar Heat Loads.

\begin{tabular}{|c|c|}
\hline Form and location of surface & Insolation for 12 hours per day \\
\hline $\begin{array}{c}\text { Flat surface transported horizontally: } \\
\text { Base } \\
\text { Other surfaces }\end{array}$ & $\begin{array}{c}\text { None } \\
\text { Each surface }\end{array}$ \\
\hline $\begin{array}{c}\text { Flat surface not transported horizontally: } \\
\text { Each }\end{array}$ & $162 \mathrm{cal} / \mathrm{cm}^{2}\left\{597 \mathrm{BTU} / \mathrm{ft}^{2}\right)$ \\
\hline Curved surfaces & $324 \mathrm{cal} / \mathrm{cm}^{2}\left\{1,194 \mathrm{BTU} / \mathrm{ft}^{2}\right\}$ \\
\hline
\end{tabular}

\subsubsection{Acceptance Criteria}

The criterion for acceptable performance of the self-container packages are the accessible surfaces of the package in still air at $46^{\circ} \mathrm{C}\left(115^{\circ} \mathrm{F}\right)$ and in the shade are not to exceed $85^{\circ} \mathrm{C}$ $\left(185^{\circ} \mathrm{F}\right)$. This is based on the self-container package being transported as an exclusive use shipment. For the structural evaluation, the maximum external temperature with insolation is limit to $100^{\circ} \mathrm{C}\left(212^{\circ} \mathrm{F}\right)$ to prevent significant loss of structural integrity of metallic and non-metallic components. When exterior temperature exceed this limit or package components have a lower temperature thresholds the package shall be protected from solar insolation during transported.

\subsubsection{Thermal Evaluation and Conclusions}

For this evaluation the self-container packages are assumed to not be subjected to any significant heat loads. In the evaluations, the self-container packages are assumed to be exposed the worst case solar heat loading for a period of 12 hours. This provides a conservative estimate of the resulting temperature of the package.

Results of this evaluation, Part B, Section 8.5 show the maximum outer surface temperatures of a worst case self-container packages under insolation is $87^{\circ} \mathrm{C}\left(189^{\circ} \mathrm{F}\right)$ for the structural evaluation. The results also show the self-container package meets the NTC exterior surface temperature requirement of $85^{\circ} \mathrm{C}\left(185^{\circ} \mathrm{F}\right)$ in the shade for exclusive use shipments. The calculated temperature in the shade of the self-container packages are $46^{\circ} \mathrm{C}\left(115^{\circ} \mathrm{F}\right)$, which is essentially ambient.

\subsection{REFERENCE}

Fadeff, J. G., 1992, WHC-SD-TP-RPT-004, Environmental Conditions for On-site Hazardous Materials Packages, Westinghouse Hanford Company, Richland, Washington. 
HNF-3341 Rev. 0

\subsection{APPENDICES}

8.5.1 Cylindrical Self-Container Thermal Evaluation

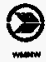

ENGINEERING SAFETY EVALUATION

Subject:_Cylindrical DES Container NTC Thermal Evaluation

Preparer: S. S. Shirage

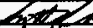

(a)

Page 1 of 4

Checker: S. N. Huang Anturang

Date $8 / 1 / 98$

Section Chief: F, J.Smith $R$, stot

Date $9 / 15 / 98$

Date $9 / 15 / 98$

\subsection{OBJECTIVE}

The objective of this evaluation is to determine the NTC exterior surface temperature of a DES container package.

\subsection{REFERENCES}

Irwin, J. J., 1995, WHC-SO-TP-RPT-005, Rev. 1, Thermal Analysis Methods for Safety Analysis Reports for Packaging. Weatinghouse Hanford Company, Richland, Wash.

Fadeff, J. G., 1992, WHC-SD-TP-RPT-004, Rev. 0, Environmental Conditions for On-site Hazardous Material Packages, Westinghouse Hanford Company, Richland, Wash.

ORNL, 1970, Cask Designer's Guide, ORNL-NISC-68, Oak Ridge National Laboratory, Oak Ridge, Tennessee.

Mathcad Plus 5, 1994, User's Guide, Math Soft Inc., Cambridge, Massachusetts.

\subsection{ASSUMPTIONS, RESULTS, AND CONCLUSIONS}

In this evaluation, it is conservatively assumed that the sun shines on the drum for $12 \mathrm{hrs}$ at the worst solar angle. It is also assumed that the drum is suspended in the air, so as to conservatively negate conduction exterior to the package. A cylindrical Decontaminated Equipment Self Container package with dimensions $8 \mathrm{ft}$ in diameter and $\mathbf{4 0} \mathrm{ft}$ long and fabricated from stainless steel is assumed.

Results of the evaluation show that under worst case solar insolation the exposed external surface temperature of the drum is $87^{\circ} \mathrm{C}\left(189^{\circ} \mathrm{F}\right)$. In the shade the external temperature of exposed drum surfaces is $46^{\circ} \mathrm{C}\left(115^{\circ} \mathrm{F}\right)$. Based on this evaluation, it is demonstrated that the exposed external surface temperature of the drum is below the temperature required for normal non-exclusive use transport of a Decontaminated Equipment Self Container package. 
은

ENGINEERING SAFETY EVALUATION

Subject: Cylindrical DES Container NTC Thermal Evaluation

Preparer:S.S. Shirage

Checker: $s_{1} N$. Hueng And

Page 2 of 4

Section Chief: R.J. Smith $\triangle Q \angle$

\subsection{EVALUATION}

Norma L Transport Conditions (NTC) Thermal Exalnation:

Determine temperature of outer shell with and without solar insolation:

Evaluate as steady state heat transfer for a horizontal cylinder with flat plate ends (Irwin, 1995):

Free convection coefficient for a horizontal cylinder: $\quad k_{h e}:=0.27 \frac{\mathrm{BTU}}{\mathrm{hr} \cdot \mathrm{ft}^{2} \cdot \mathrm{F}}$

Free convection coefficient for a vertical plate; $\quad k_{v p}=0.29 \frac{B T U}{\mathrm{hr} \cdot \mathrm{ft}^{2} \cdot \mathrm{F}}$

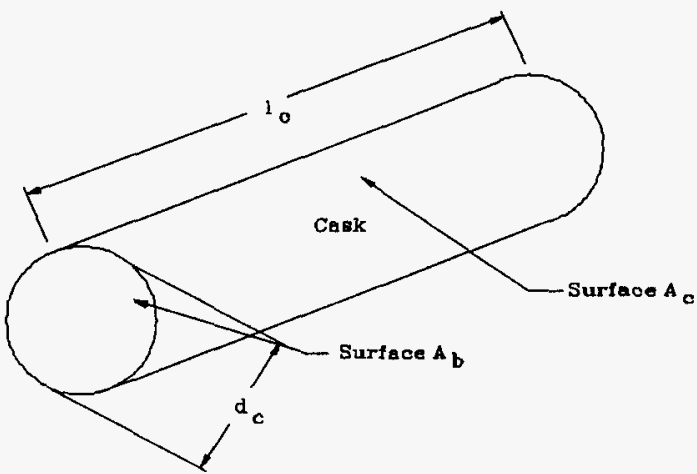

Length of cylinder: $\quad t_{c}=40-\mathrm{ft} \quad$ Diameter of plate: $\quad d_{c}-8 \cdot f t$

Surface area of cylinder: $\quad A_{c} \cdot \pi \cdot c^{\cdot} \cdot d_{c} \quad$ Surface area of plate: $\quad A_{b}: \frac{\pi}{4} \cdot d_{c}{ }^{2}$

MUWW-PE-001R 
HNF-3341 Rev. 0

(2)

ENGINEERING SAFETY EVALUATION

Subject:Cylindrical DES Container NTC Thermal Evaluation

Preparer: S. S. Shiraga

Checker: $S, N$, Huang.

Page 3 of 4

Section Chief:_R.J. Smith $R$

Date_8/1/98

Date $29 / 15 / 98$

Convection coefficients:

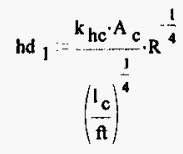$$
\text { hd } 2: \frac{k_{v_{p}} \cdot 2 \cdot A_{b}}{\left(\frac{d_{c}}{f t}\right)^{\frac{1}{4}}} R^{-\frac{1}{4}}
$$

Radient heating constant:

$$
\sigma_{s b}:=0.171410^{-8} \cdot \frac{B T U}{h r \cdot \mathrm{ft}^{2} \cdot \mathrm{R}^{4}}
$$

Emissivity of stainless steel: $\quad E_{s}:=0.15$

Radiation coefficients

$$
K_{1}=\sigma_{s b} \cdot \varepsilon_{s} \cdot A_{c}
$$$$
K_{2}:=\alpha_{s b} \cdot \varepsilon_{s} \cdot 2 \cdot A_{b}
$$

Solar heat loading (Irwin, 1995), hourly average loading based on a $12 \mathrm{hr}$ period:

Curved surfaces: $Q_{\mathrm{s} 1}:=314 \frac{\text { watt }}{\mathrm{m}^{2}} \quad \mathrm{Q}_{\mathrm{s} 1}=99.54 \cdot \frac{\mathrm{BrU}}{\mathrm{hr} \cdot \mathrm{ft}^{2}}$

Non-vertical surfaces: $\quad Q_{\mathrm{s}}-\frac{Q_{\mathrm{s}]}}{2} \quad Q_{\mathrm{s}}=49.77 \cdot \frac{\mathrm{BTU}}{\mathrm{hr} \cdot \mathrm{ft}^{2}}$

Internal heat load: $\quad \mathbf{q}_{\text {int }}:=0 \cdot$ watt $\varnothing$

Assumed solar absorptivity: $\quad \alpha_{\text {sol }}:=0.37$

Solar heat load: $\quad q_{\text {sol }}:=\alpha_{\text {sol }} \cdot\left(Q_{s} \cdot A_{b}+Q_{s t} \cdot \frac{A_{c}}{2}\right)$

Total heat load: $\quad q_{\text {tot }}=q_{\text {sol }}+q_{\text {int }} \quad q_{\text {tot }}=19438 \cdot \frac{\text { BTU }}{h r}$

Outside ambient temperature is $115^{\circ} \mathrm{F}$ and in Rankine: $\quad T_{0}:(115+459.7) \cdot R$

Using conservation of energy: $\quad q_{\text {in }}-q_{\text {out }}=0$

WMHW-PE-001/2 
HNF-3341 Rev. 0

8

ENGINEERING SAFETY EVALUATION

Subject: Cylindrical DES Container NTC Thermal Evaluation

Preparer: S. S. Shirega

Checker: S. N. Huang

Page 4 of 4

Date $8 / 1 / 98$

Section Chief:_R, J, Smith $\propto$ At

Date 9/15/98

Date 9/15/98

Then by substitution: $\quad q_{\text {tot }}-q_{\mathrm{rad}} \cdot q_{\text {con }}=0 \quad$ or

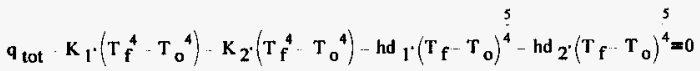

Solve for $T_{f}$ which the temperature at the surface using MathCad roots of equation solution:

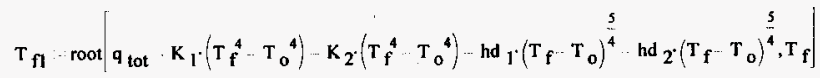

External surface temperature in sun: $\quad T_{f 1}=649 \cdot R$

Temperature in ${ }^{\circ} \mathrm{F}: \quad \mathrm{T}_{\mathrm{ff}}-\frac{\mathrm{T}_{\mathrm{fl}}-459.7 \mathrm{R}}{\mathrm{R}} \quad \mathrm{T}_{\mathrm{ff}}=189 \quad 0$

Temperature in Shade:

Total shaded heat load: $\quad \mathbf{q}_{\text {stot }}=\mathbf{q}_{\text {int }}$

Solve for $T_{f}$ which the temperature at the surface using MathCad roots of equation solution:

$$
T_{f 2}=\operatorname{root}\left|q_{s t o t}-K_{1} \cdot\left(T_{f}^{4} \cdot T_{0}^{4}\right)-K_{2} \cdot\left(T_{f}^{4}-T_{0}^{4}\right)-h d_{1} \cdot\left(T_{f^{-}} T_{0}\right)^{\frac{5}{4}}-h d_{2} \cdot\left(T_{f^{-}}-T_{0}\right)^{4}, T_{f}\right|
$$

External surface temperature in shate: $\quad T_{f 2}=575-R$

Temperature in ${ }^{\circ} \mathrm{F}: \quad \mathrm{T}_{\mathrm{ff2}} \frac{\mathrm{T}_{\mathrm{f2}} \cdots 459.7 \mathrm{R}}{\mathrm{R}} \quad \mathrm{T}_{\mathrm{ff2}}=115$ 
HNF-3341 Rev. 0

\subsubsection{Cuboid Self-Container Thermal Evaluation}

\section{ENGINEERING SAFETY EVALUATION}

Subject: Cuboid DES Container NTC Thermal Evaluation Preperer:S. S. Shirege Checker: S.N.Huang on / fuany Page 1 of 5 Date $9 / 15 / 98$ Section Chief: R.J.Smith R/ADt Date 9/15/98

\subsection{OBJECTIVE}

The objective of this evaluation is to determine the NTC exterior surface temperature of a cuboid DES container package.

\subsection{REFERENCES}

Irwin, J. J., 1995, WHC-SD-TP-RPT-O05, Rev. 1, Thermal Analysis Methods for Safoty Anelysis Reports for Packaging, Westinghouse Hanford Company, Richland, Wash.

Fadeff, J. G., 1992, WHC-SD-TP-RPT-004, Rev. 0, Environmental Conditions for On-site Hazardous Material Packages, Westinghouse Hanford Company, Richland, Wash.

ORNL, 1970, Cask Designer's Guide, ORNL-NISC-68, Oak Ridge National Laboratory, Oak Ridge, Tennessere.

Mathcad Plus 5, 1994, User's Guide, Math Soft Inc., Cambridge, Massachusetts.

\subsection{ASSUMPTIONS, RESULTS, AND CONCLUSIONS}

In this evaluation, it is conservatively assumed that the sun shines on the drum for 12 hrs at the worst soler angle. It is also essumed that the drum is suspended in the air, so es to conservatively negate conduction exterior to the package. A cuboid Decontaminated Equipment Self Container package with dimensions $8 \mathrm{ft}$ wide by $10 \mathrm{ft}$ high by $40 \mathrm{ft}$ long and fabricated from stainless steel is assumed.

Results of the evaluation show that under worst case solar insolation the exposed external surface temperature of the drum is $83^{\circ} \mathrm{C}\left(182^{\circ} \mathrm{F}\right)$. In the shade the external temperature of exposed drum surfaces is $46^{\circ} \mathrm{C}\left(115^{\circ} \mathrm{F}\right)$. Based on this evaluation, it is demonstrated that the exposed external surface temperature of the drum is below the temperature required for normal non-exclusive use transport of a Decontaminated Equipment Self Container package. 
HNF-3341 Rev, 0

(ㄱ)

ENGINEERING SAFETY EVALUATION

Subject: Cuboid DES Container NTC Thermal Evaluation

Preparer:_S.S. Shiraga Led

Page 2.of 5

Checker: S.N. Huang Ant

Date $8 / 1 / 98$

Section Chief: R.J.Smith A.

Date $9 / 15 / 98$

Date $9 / 15 / 98$

\subsection{EVALUATION}

Thermal Evaluntion of DES Container:

Determine temperature of outer surface with insolation. Assume sun shines on top, one end face, and one side face. For conservatism, assume the DES Container is suspended in the air.

Evaluate as steady state heat transfer for DES Container idealized as a rectangular cuboid:

Free convection coefficients from Irwin, 1995.

Free convection coefficient for a vertical plane: $\quad k_{v p}-0.29 \frac{B T U}{\mathrm{hr}_{\mathrm{f}} \mathrm{ft}^{2} \cdot \mathrm{F}}$

Free convection coefficient for a horizontal surface with hot surface facing up: $\quad k_{h s}:=0.27 \frac{\text { BTU }}{h r \cdot \mathrm{At}^{2} \cdot \mathrm{F}}$

Free convection coefficient for a horizontal surface with cold surface facing up: $\quad k_{c s}:=0.12-\frac{\text { BTU }}{h r \cdot f^{2} \cdot F}$

Length of horizontal surface: $\quad 1_{h s}-40 \mathrm{ft} \quad$ Height of vertical plane: $h_{\mathrm{vp}}:=10 \mathrm{ft}$

Width of horizontal and vertical surface: $w_{\text {hs }}:=8 \cdot \mathrm{ft}$

Area of horizontal flat surfaces with hot side facing up:

$A_{\text {hsh }}:=I_{\text {hs }} \cdot \mathbf{w}_{\text {hs }}$

Area of horizontal flat surface with cold side facing up:

$A_{\text {hsc }}:=I_{\text {hs }} \cdot \mathbf{w}_{\text {hs }}$

Area of short vertical plane: $\quad A_{\text {svp }}: h_{\mathrm{vp}} \cdot w_{h s} \quad$ Area of long vertical plane: $\quad A_{\text {Ivp }}=h_{v p} \cdot h_{h s}$

Total area: $\quad \mathbf{A}_{\text {tot }}:=\mathbf{A}_{\text {hsh }}+\mathbf{A}_{\text {hsc }}+2 \cdot \mathbf{A}_{\text {svp }}+2 \cdot \mathbf{A}_{\text {lvp }}$

Combined convection constant:

$$
\text { hd }=\left[\frac{k_{v_{p}} \cdot\left(A_{s v p}\right)}{\left(\frac{h v p}{f t}\right)^{\frac{1}{4}}}+2 \cdot \frac{k_{v p} \cdot\left(A_{\text {lvp }}\right)}{\left(\frac{1}{f t}\right)^{\frac{1}{4}}}+\frac{k_{h s} \cdot A_{h s h}}{\left(\frac{1}{f t}\right)^{\frac{1}{4}}}+\frac{k_{c s} \cdot A_{h s c}}{\left(\frac{1}{f t}\right)^{\frac{1}{4}}}\right] \cdot R^{-\frac{1}{4}}
$$


HNF-3341 Rev. 0

$\Theta$

\section{ENGINEERING SAFETY EVALUATION}

Subject: Cuboid DES Container NTC Thermal Evoluation

Preparer:S.S. Shiraga

2

Page 3 of 5

Checker: S.N. Huang

Date $8 / 1 / 98$

Section Chief: R.J. Smith

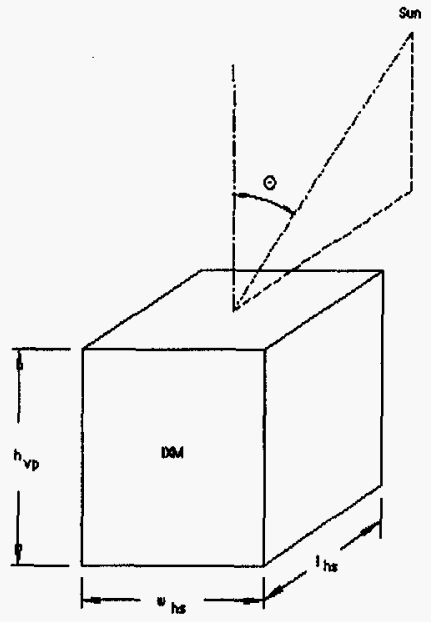

Stefan-Boltzman's natural constant: $\quad \sigma_{\mathrm{sb}}=0.171410^{-8}, \frac{\mathrm{BTU}}{\mathrm{hr} \cdot \mathrm{ft}^{2} \cdot \mathrm{R}^{4}}$

Assumed e missivity of polsihed stainless steel at 100 of (Irwin, 1995): $\varepsilon$ pes $:=0.15$

Solar absorptivity (Irwin, 1995) a sol $:=0.37$

Radient heating constant: $\quad \mathrm{K}_{1}-\sigma_{\mathrm{sb}} \mathrm{A}_{\text {tot }}{ }^{\varepsilon}$ pcs

$K_{1}=4.11 \cdot 10^{-7} \cdot \frac{\mathrm{BTU}}{\mathrm{hr} \cdot \mathrm{R}^{4}}$

MunH-PE-0010 


\section{ENGINEERING SAFETY EVALUATION}

Subject: Cuboid DES Container NTC Thermal Evaluation

Preparer: $S, S$, Shiraga

Checker: S.N.Hueng

Section Chief: A. J, Smith

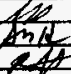

Page 4 of 5

Date $8 / 1 / 98$

Date $9 / 75 / 98$

Date $9 / 15 / 98$

Determination of solar loading from Cask Designers Guide (ORNL, 1970):

Assume solar angle of declination relative to vertical azimuth for maximum loading: $\quad \theta_{\mathrm{sol}}:-30 \mathrm{deg}$

Solar heat loading for various surfaces, hourly average loading based on a $12 \mathrm{hr}$ period:

Solar heat loading is from Fadeff, 1992, page 8 \& 9.

Flat horizontal surfaces: $\quad q_{\mathrm{fsh}}:=2386 \frac{\mathrm{BTU}}{\mathrm{ft}^{2}} \quad$ Flat surfaces not horizontal: $\quad q_{\mathrm{fsv}}:=597 \cdot \frac{\mathrm{BTU}}{\mathrm{ft}^{2}}$

Solar heat loading for hourly averaged loading based on a $12 \mathrm{hr}$ period: $\quad \mathrm{t}_{\mathrm{hr}}:-12 \cdot \mathrm{hr}$

Flat horizontal surfaces: $Q_{\mathrm{fsh}}: \frac{q_{\mathrm{fsh}}}{\mathrm{t}_{\mathrm{hr}}} \quad Q_{\mathrm{fsh}}=627 \cdot \frac{\text { watt }}{\mathrm{m}^{2}}$

Flat surfaces not horizontal: $\quad Q_{\mathrm{fsv}}: \frac{{ }^{\mathrm{q} f \mathrm{fv}}}{t_{\mathrm{hr}}} \quad Q_{\mathrm{fsv}}=157 \cdot \frac{\text { watt }}{\mathrm{m}^{2}}$

Conservative internal heat load: $\quad \mathbf{q}_{\text {int }}:-0$-watt

Solar heat load based on three faces of the cuboid exposed to sunlight:

$$
q_{\text {sol }}:=a_{\text {sol }}\left[Q_{f_{s h}} \cdot A_{h s h} \cdot \cos \left(\theta_{\text {sol }}\right)+Q_{f s v} \cdot\left(A_{\text {svp }}+A_{\text {lvp }}\right) \cdot \sin \left(\theta_{\text {sol }}\right)\right] \quad q_{\text {sol }}=7270^{*} \text { watt }
$$

Total heat load: $\quad q_{\text {tot }}=\mathbf{q}_{\text {sol }}+\mathbf{q}_{\text {int }}$

Ambient temperature in ${ }^{\circ} \mathrm{F}: T_{\mathrm{a}}=115$ Ambient temperature in Rankine: $T_{0}:=\left(T_{a}+459.7\right) \cdot R T_{0}=575-$

Using conservation of energy: $\quad q_{\text {in }}-q_{\text {out }} \neq 0$

Then: $\quad q_{\text {tot }} q_{\text {rad }}-q_{\text {con }}=0 \quad$ or $\quad q_{\text {tot }}-K_{r}\left(T_{f}^{4}-T_{0}^{4}\right) \cdots h d \cdot\left(T_{f^{-}}-T_{0}\right)^{\frac{5}{4}}=0$

Solve for Tf which is the temperature at the surface using MathCad roots of equation solution:

$$
T_{f}:=\operatorname{root}\left[q_{t o t}-K_{l} \cdot\left(T_{f}^{4}-T_{0}^{4}\right)-h d \cdot\left(T_{f}-T_{0}\right)^{\frac{5}{4}}, T_{f}\right]
$$

WMANPE-DO1R 
HNF-3341 Rev. 0

(2)

ENGINEERING SAFETY EVALUATION

Subject: Cuboid DES Container NTC Thermal Evaluation

Preparer: S. S. Shirege

Checker: S. N. Huang

$\ln x$

Page 5 of 5

Section Chief: R. J. Smith

Date $8 / 1 / 98$

Section Chief: R. J. Smith

External surface temperature in sun: $T_{f}=641 \cdot R$

Temperature in ${ }^{\circ} \mathrm{F}$ in the sun: $\quad \mathrm{T}_{\mathrm{ff}}-\frac{T_{f^{-}}-459.7 \mathrm{R}}{R} \quad T_{\mathrm{ff}}=182$

Determination of temperature without solar insolation:

Total shade heat load: $\quad \mathbf{q}_{\text {tot }} \quad \mathbf{q}_{\text {int }}$

Using same method as above determine temperature in the shade:

Solve for $T_{f}$ which is the temperature at the surface using MathCad roots of equation solution:

$$
\left.T_{f 1}=\operatorname{root} \mid q_{\text {tot }}-K_{\mathrm{r}}\left(T_{f}^{4}-T_{0}^{4}\right)-\text { hd } \cdot\left(T_{f^{-}} T_{o}\right)^{\frac{5}{4}}, T_{f}\right]
$$

External surface temperature in sun: $T_{\mathrm{fl}}=575 \cdot \mathrm{R}$

Temperature in ${ }^{\circ} \mathrm{F}$ in the sun: $\quad T_{\mathrm{ff}}=\frac{\left|T_{\mathrm{f1}}-459.7 \mathrm{R}\right|}{\mathrm{R}} \quad \mathrm{T}_{\mathrm{ff}}=115$ 
HNF-3341 Rev. 0

This page intentionally left blank.

B8-12 
HNF-3341 Rev. 0

\subsection{PRESSURE AND GAS GENERATION EVALUATION}

The residual material within the self-container will be fixed to interior surfaces. No liquids of any kind, except for residual quantities that cannot be practically removed, will be allowed inside the container.

The self-container is not permitted to contain chemical forms, such as organic or hydrogenous compounds, which can produce hazardous gases. Therefore, there are no hazards associated with pressure build-up or flammable gases and no analyses are required. 
HNF-3341 Rev. 0

This page intentionally left blank.

B9-2 


\subsection{PACKAGE TIEDOWN SYSTEM EVALUATION}

\subsection{INTRODUCTION}

In application of this SARP, the underlying premise is that the package remains on the conveyance for all normal transfer conditions. Since there is a wide variation in package geometries and weights that can be shipped under this SARP, additional securement requirements are imposed to supplement 49 CFR 393.100 requirements. Due to the importance of the securement system for shipment under this SARP, these supplemental requirements require the securement system to exceed the requirements set forth in the DOT regulations.

Because of the variability of center of gravity, geometry, and weight of packages that can be shipped under this SARP, the evaluations in Part B, Section 10.5 envelopes the possible geometries as a $12 \mathrm{~m}(40 \mathrm{ft})$ long by $2.5 \mathrm{~m}(8 \mathrm{ft})$ wide by $3 \mathrm{~m}(10 \mathrm{ft})$ high cuboid and a $12 \mathrm{~m}$ $(40 \mathrm{ft})$ long by $2.5 \mathrm{~m}(8 \mathrm{ft})$ diameter cylinder. The evaluations also envelope package weight by assuming the package weight established for shipment under this SARP as $22,680 \mathrm{~kg}(50,000 \mathrm{lb})$. In the case of cuboid packages the center of gravity is conservatively assumed as the $2 / 3$ the distance from the base of the package. For cylindrical packages, the center of gravity is assumed as the geometric center of the cross section.

Package parameters specified above are for packages which can be transported by standard conveyances. Oversized packages having geometries and/or weights which exceed the above specified parameters may be transported under this SARP under the following conditions:

1. All of the supplemental requirements specified in Part B, Section 10.2 shall be met.

2. The conveyance to be used shall have sufficient distributed and concentrated load capacities to transport the package.

3. An authorized representative of WMNW Transportation Logistics shall approve the tiedown and blocking configuration.

\subsection{SYSTEM DESIGN}

The primary objective of these supplemental requirements is to prevent significant shifting of the package and to prevent the package from tipping over or rolling off the conveyance. The package must remain on or within the conveyance under all normal conditions and when responding to emergency situations, short of an accident. These requirements account for maneuvering of the conveyance such as hard braking and response to emergency situations. The following additional requirements adopted from recommendations in the University of Michigan Transportation Research Institute Report (UMTRI 1987) and A Uniform Cargo Securement Standard for Highway Transport Vehicles (CCMTA 1997), to 49 CFR 393.100 for packages transported under this SARP are:

Packages with a weight of greater than or equal to $460 \mathrm{~kg}(1,000 \mathrm{lb})$ are subject to the additional requirements of this section. Packages under $460 \mathrm{~kg}(1,000 \mathrm{lb})$ shall be secured in accordance with the requirements of 49 CFR 393.100 .

Packages shall be centered on the width of the conveyance. The long axis of the package shall be placed on the long axis of the conveyance.

The surface of the conveyance shall be clean, dry, and free of any loose material, debris, and oils. All materials used to increase frictional resistance and the surface on which they are to be placed shall be clean, dry, and free of any loose material, debris, and oils. 
The total aggregate strength of the securement system shall be no less than 0.75 times the weight of the package in any horizontal direction.

For securement, vertical tiedown angles shall be no less than $30^{\circ}$ off the deck of the conveyance and horizontal tiedown angle shall be no less than $45^{\circ}$. Tiedowns shall be tightened with ratchet binders or other tightening devices, and must be taunt with no visible slack in any of the legs.

To restrain horizontal movement and reduce tiedown loads all packages shall be blocked and braced in all horizontal directions. Blocking and bracing shall be accomplished by either chock blocks secured to the deck of the conveyance or with chocking chains or with a combination of the two. As a supplement to blocking and bracing and to reduce loads, friction increasing commercial load mats are acceptable for use. However, the mating surface of the mats and package shall be clean, dry, and free of loose material and debris. Also, to increase frictional resistance for chocking chains, rubber padding or wood blocks shall be placed between the package and the chains.

Cradles shall be provided for spherical or cylindrical shaped packages to prevent load shifts due to rolling. The ratio between the cradle and cylinder contact (W) to the diameter of the cylinder (D) shall be equal to or greater than 5 to 8 , which is equivalent to a wedge angle of $39^{\circ}$ (see Figure B10-1). Also the minimum overall height of the cradles shall no less than $1 / 5$ the distance between the cradles.

Figure B10-1. Cradle Schematic.

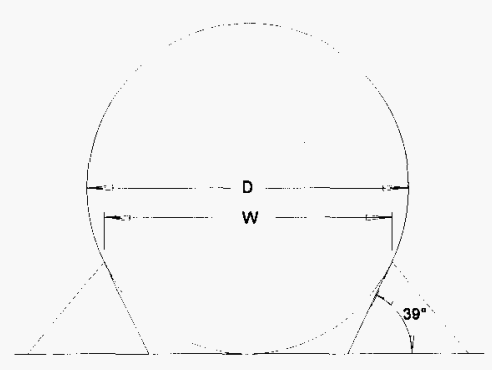

\subsection{ATTACHMENTS, RATINGS AND REQUIREMENTS}

The total aggregate working load limit of the tiedowns shall be no less than 0.75 times the weight of the package in any direction. On each tiedown leg, couplings and binders shall have a rated working load equal or greater than the working load limit of the tiedown. Attachment of the tiedowns shall be to the main structure of the conveyance to the maximum extent practical or to D-rings or other tiedown points provided on the conveyance. Attachment shall not be made to stake pockets and attachment to rub rails shall be avoided. When attaching to the rub rails is necessary, attachment shall be made not to the rub rail itself but to the structural member extending from the conveyance side beams on which the rub rail is attached.

Chock chains and blocking shall have a capacity no less than 0.75 times the weight of the package in the direction of loading. Chains used for chocking shall have a minimum working load limit of 0.75 times the weight of the package. On each leg of the chocking chains couplings, 
shackles, D-rings, and binders shall have a rated working load limit equal or greater than the chain. Attachment to the conveyance shall follow the same guidelines as established above. When lumber is used for cradles and blocking, there shall be sufficient length and size of lumber to limit the compressive load on the wood to $12.9 \mathrm{~cm}^{2}\left(2 \mathrm{in}^{2}\right)$ per $460 \mathrm{~kg}(1,000 \mathrm{lb})$ of load. The lumber shall be commercial grade, straight-grained and free of decay and strength impairing knots. As a minimum, each length of lumber shall be secured the deck of the conveyance with twelve (12) $16 \mathrm{~d}$ nails. The lumber shall be predrilled nail holes which are staggered with a minimum spacing of $10 \mathrm{~cm}(4 \mathrm{in}$.$) . The nails shall be driven at right angles to the conveyance deck.$

On the Hanford Site the most common tiedowns are $1 / 2$ in alloy chains with a working load limit of $5,900 \mathrm{~kg}(13,000 \mathrm{lb})$ which are used in combination with ratchet binders with a working load limit of $5,900 \mathrm{~kg}(13,000 \mathrm{lb})$. In most cases this chain size will meet the requirements set forth in this section. However, when loadings require higher working load limits, multiple chains and binders may be used to provide the required working load limit. When multiple chains are used that have common attachment end points or wrap around the package (i.e., chock chains), shall be of the same length and tied together at the ends with shackles or D-rings.

\subsection{REFERENCES}

49 CFR 393.100, 1995, Protection Against Shifting or Falling Cargo, Code of Federal Regulations, as amended.

CCMTA 1997, A Uniform Cargo Securement Standard for Highway Transport Vehicles, Canadian Council of Motor Transport Administrators, Ottawa, Canada.

UMTRI 1987, Engineering Analysis of Cargo Restraint on Commercial Highway Trucks, UMTRI-87-28, The University of Michigan Transportation Research Institute, Ann Arbor, Michigan. 
HNF-3341 Rev. 0

10.5 APPENDIX: TIEDOWN REQUIREMENTS EVALUATION

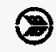

ENGINEERING SAFETY EVALUATION

Subject:_DES Container Tiedown Reguirements Eveluation Page 1 of 11 Preparer: 5. S. Shirega Date $09 / 08 / 98$ Section Chief: B.J. Smith $R$ Ret Date $09 / 10 / 98$

\subsection{OBJECTIVE}

The objective of this evaluation is to envelope load securement parameters for safe transport of the Decontaminated Equipment Self Container for NTC.

\subsection{REFERENCES}

Patterson, 1988, Patterson Products, W. W. Patterson Company, Pittsburgh, Pennsylvania.

49 CFR 393.100, 1995, "Protection Against Falling Cargo," Subpart I, Code of Federa/ Regulations, as amended.

CCMTA, 1997, A Uniform Cargo Securement Standard for Highway Transport Vehicles, Canadian Council of Motor Transport Administration, Ottawa, Ontario, Canada.

Wood Engineering Handbook, 1986, Wood Engineering Hendbook by U.S. Forest Products Laboratory, Prentice-Hall, Inc., Englewood Cliffs, New Jersey.

UMTRI, 1987, Engineering Analysis of Cargo Restraint on Commercial Highway Trucks, UMTRI87-28, The University of Michigan Transportation Research Institute, Ann Arbor Michigan.

\subsection{ASSUMPTIONS, RESULTS, AND CONCLUSIONS}

In this evaluation, two configurations of a package with a gross weight of $50,000 \mathrm{lb}$, a cuboid and cylinder, are used to envelope the tiedown parameters. The cuboid package is conservatively assumed to be $40 \mathrm{ft}$ long by $10 \mathrm{ft}$ tall by $3 \mathrm{ft}$ wide. This assumed width to height ratio of the package makes the package prone to tip over, providing conservative tiedown parameters. For added conservatism, the center of gravity for this package is assumed as $2 / 6$ the distance from the bottom of the package. The cylindrical package is assumed as $8 \mathrm{ft}$ in diameter by $40 \mathrm{ft}$ long with the center of gravity at the geometric center of the package. In the case of the cylindrical package the geometric center is chosen for a center of gravity, since most cylindrical packages have a center of gravity either at or below the geometric center. Also in the case of cylindrical packages the major concern is not tip over but rolling off the conveyance. For both 
HNF-3341 Rev. 0

\section{ENGINEERING SAFETY EVALUATION}

Subject:_DES Container Tiedown Requirements Evaluation

Preperer: S.S. Shirage Sule

Page 2 of 11

Section Chief: R. J. Smith X/L Date 09/10/98

configurations, the package is assumed to be placed on a commercial load mat to increase frictional resistance to sliding and thereby reduce tiedown loads. It is also assumed that either wood blocks or rubber pads are placed between the tiodown and package to increase frictional resistance to sliding of the tiedown. In all cases the tiedown is assumed to be $y_{2}$ in Grade 8 allov chain with a working load limit of $13,000 \mathrm{lb}$. This particular type and size of chain is the most common chain available on the Hanford Site. For shipment of DES Container packages, it is assumed that the packages will be blocked and braced either with lumber nailed to the deck or chocking chains secured to the conveyance to prevent load shifting and reduce tiedown loads. Since the NTC performance of this package is predicated on the package remaining on the conveyance, the aggregate working load of the tiedowns and chocking chains shall exceed DOT requirements and is specified as 0.75 times the gross weight of the package.

The results of the evaluation show for large and heavy cuboid packages with a high center of gravity, securement requirements can be met with $1 / 2$ in alloy chain and binding equipment with a working loed limit of $13,000 \mathrm{lb}$. Also in meeting these requirements either chock chains or blocking and bracing with lumber are required along with the following conditions:

- The package is centered on the conveyance with the long axis in the direction of travel.

- A nominal frictional resistance is obtained by added of a commercial load mat. and ensuring that all critical friction surfaces are clean, dry, and free of oil or any other contaminants.

- All contact surfaces between the tiedowns and package are provided with either wood or rubber load pads to increase frictional resistance.

- The package is adequately blocked and braced from sliding and load shifting with either chock chains or lumber secured to the deck of the conveyance.

- Properly rated binders are used which are tighten to take up all tiedown slack.

Results of the evaluation show for large and heavy cylindrical packages securement requirements can be met with $1 / 2$ in alloy chain and binding equipment. In the case of cylindrical packages this requires the package meet the above conditions and also requires being placed in a cradle mounted to the conveyance. The cradle can be manufactured from wood or matal, and cradle must have angle of $39^{\circ}$ with the distance between contacting surfaces of cradles as $\%$ the diameter of the package. As shown in the evaluation the minimum height of the cradle is required to be 0.2 times the distance between the cradles. The cradles must be secured to the conveyance either by nailing to the deck or chaining to the conveyance. At each longitudinal end of the cylindrical package, the package must be blocked and braced either with lumber nailed to the deck or chock chains secured to the conveyance.

These calculations are made for specific enveloping cases of common DES Container packages. Any odd or unusual shaped or high center gravity package must be evaluated on a case by cease basis. In general the aggregate working load limit of the tiedowns for DES Container 
HNF-3341 Rev. 0

은

ENGINEERING SAFETY EVALUATION

Subject: DES Container Tiedown Requirements Evaluation

Page 3 of 11.

Preparer: $S, S$, Shiraga

Date $09 / 0 \mathrm{~B} / 98$

Checker: S. N. Hueng

Date $09 / 10 / 98$

Section Chief: R.J. Smith $\times q A / 2$ Date_09/10/98

packages must be at minimum $3 / 4$ the weight of the package. All packages are required to blocked and braced and placed with load mats. The tiedown also required binder of equal strength to the chain. 
HNF-3341 Rev. 0

을

\section{ENGINEERING SAFETY EVALUATION}

Subject: DES Container Tiodown Requirements Evaluation

Preparer:S, S, Shiraga

Page 4 of 11

Checker: S.N. Huang AMC

Date $09 / 08 / 98$

Section Chief: R. J. Smith

Date $09 / 10 / 98$

Date $09 / 10 / 98$

\subsection{EVALUATION}

Self Container Enveloping Tiedown Evaluation for Cuboids and Cylinders:

Evaluation based on maximum working load limit of chains and binders as $13,000 \mathrm{lb}$.

Pretension from ratchet binders, based on a $11 \mathrm{in}$. handle with nominal effort (Patterson 1988): $P_{0}:-4000 \mathrm{lbf}$

Assumed inertial loading: $a_{h}:=0.75$ Enveloping weight of container: Wpac $:=50000$ lbf

Assume load mat is provide to increase friction and friction increasing material between package and chain.

Friction factor of load mat: $\mu_{\text {mat }}:=0.5 \quad$ Friction factor of package to chain: $\quad \mu_{\mathrm{pc}}:=0.4$

Cubold Package:

Assumed enveloping cuboid package dimensions:

Height: hp :=10 ft Length: $\quad$ lp : $:-40 \mathrm{ft}$

For conservatism assume a narrow width package: Width: wp :=3.ft

Assume dimensions of trailer: Length: Itr : $=44 \mathrm{ft}$ Width: wtr :=-10 ft

Center of gravity of package: heg $: \frac{2}{3} \cdot h p$

Longitudinal loading: Flong :- $\mathbf{a}_{\mathbf{h}}$-Wpac $\quad$ Flong $=37500^{\circ} \mathrm{lbf}$

Lateral loading: $\quad$ Flat : $=\mathbf{a}_{\mathbf{h}} \cdot$ Wpac $\quad$ Flat $=37500 \cdot 1 \mathrm{bf}$

Vertical loading: Fvert $:=a_{h}$. Wpac $\quad$ Fvert $=37500 / \mathrm{lbf}$

Chocking ehains for blocking and bracing:

Assume lateral distance from edge of package to trailer attachment:

celv $:=\frac{w t r-w p}{2} \quad \operatorname{cclv}=3.5 \mathrm{ft}$

Assume longitudinal distance end of package to trailer attachment:

cclh : $=4 \mathrm{ft}$

Longitudinal loading on chock chain:

Number of legs engaged: $\quad n_{\text {Icc }}=2 \quad$ Chock chain angle: $\quad a_{c c}:=\operatorname{atan}\left(\frac{\mathrm{cclh}}{\operatorname{cclv}}\right)$

Tiedown angle off deck: $\quad-$ atan $\left(\frac{\text { cclv }}{h p}\right)$ 
$\theta$

Subject: DES Container Tiedown Requirements Evaluation Preparer: S, S, Shiraga

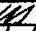

Checker: S. N. Huang

Page 5 of 11

Section Chief: $\mathrm{R}, \mathrm{d}$, Smith

Date $09 / 08 / 98$

Date $09 / 10 / 98$

Date $09 / 10 / 98$

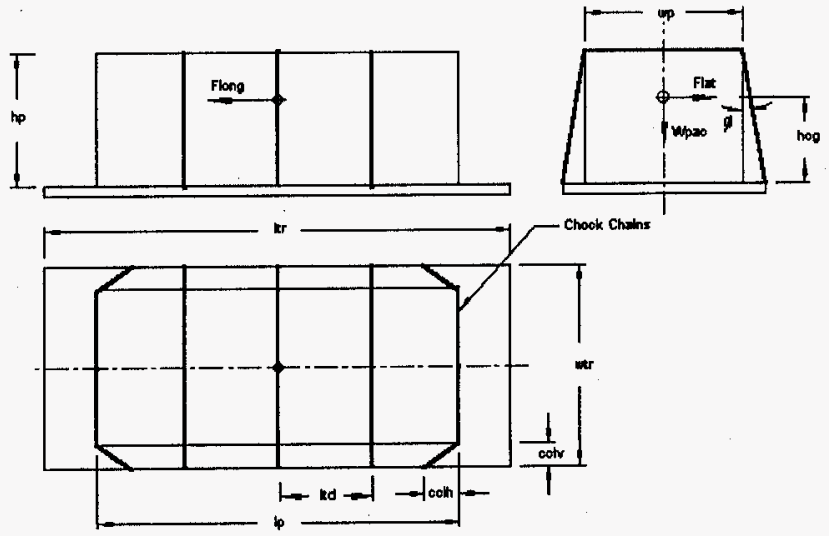

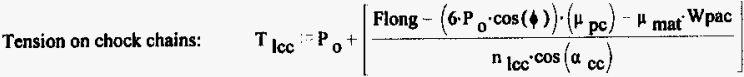

$T_{\text {lec }}=6611 \cdot l_{b f}$

Lateral loading on chock chains:

Number of legs engaged: $\quad n_{\text {lacc }}:=\mathbf{2}$

Lateral load on chock chains: $\left.\quad T_{\text {lacc }}-P_{0^{+}}+\frac{\text { Flat }-\mu_{\text {mat }} W_{p a c}-3 \cdot P_{0} \cdot\left(\mu_{p c}\right) \cdot \cos (\phi)}{n_{l a c c} \cdot \sin \left(\alpha_{c c}\right)}\right]$

$T_{\text {lacc }}=9295^{\circ} \mathrm{lbf}$

MANW-PE-001/2 
HNF-3341 Rev. 0

을

ENGINEERING SAFETY EVALUATION

Subject:_DES Container Tiedown Requirements Evaluation

Preparer: S, S. Shiraga

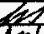

Checker: S, N. Huang Antt

Page 6 of 11

Section Chis: R.J. Smith X/A

Lateral tip over restraint load:

Number of leg engaged: $\quad \mathbf{n}_{\text {latd }}:=3$

Moment equation:

$a_{h} \cdot W$ pac $\cdot h e g ~ \cdots n_{\text {latd }} \mu_{p c} \cdot P_{0} \cdot \cos (\phi) \cdot w p-W p a c \cdot \frac{W p}{2}=n l_{\text {latd }} \cdot T$ tor $\cdot(h p \cdot \sin (\phi)+w p \cdot \cos (\phi))$

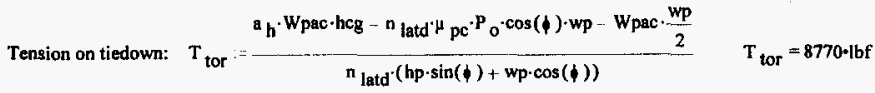

Blocking and bracing:
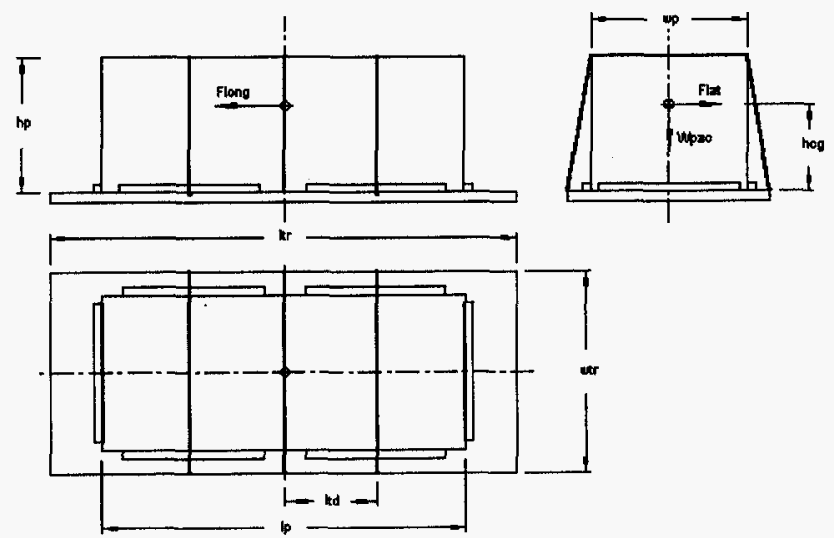

NMUMY.PE-001/2 
HNF-3341 Rev. 0

\section{ENGINEERING SAFETY EVALUATION}

Subject: DES Container Tiedown Bequirements Evaluation

Preperer: S, S. Shirage

Checker: S.N. Huang Ant

Page 7 of 11

Section Chief: R.d. Smith $\not \partial$

Timber size required to restrain load:

Assume timbers are $2 \times 4$ Soft Wood.

Allowable compressive load on timber (UMTRI 1987): $\mathrm{L}_{\text {alt }}: \frac{1000 \mathrm{lbf}}{2 \cdot \mathrm{in}^{2}} \quad \mathrm{~L}_{\text {all }}=500 \cdot \mathrm{psi}$

Length of timber: $l_{\text {tim }}=6 \cdot f t \quad$ Height of timber: $\quad h$ tim $-1.5 \cdot$ in

Compressive area of timber: $\quad A_{\text {tim }}{ }^{-1} \operatorname{tim}^{h}$ tim $\quad A_{\text {tim }}=108 \cdot$ in $^{2}$

Worst case loading is lateral loading: $\quad F_{\text {ch }}:=$ Flat $-\mu_{\text {mat }}$ Wpac $\quad F_{\text {ch }}=12500-\mathrm{lbf}$

Compressive load: $\quad \frac{F_{\text {ch }}}{A_{\text {tim }}}=116 \%$ psi $\quad$ Therefore $O K$

Number of nails required to restrain load and assuming allow $1 / 32$ in slip with $16 d$ nails.

Specific gravity of soft wood: $\quad G:=0.52 \quad$ Elastic modulus of nail: $\quad E:=27 \cdot 10^{6} \cdot \mathrm{psi}$

Assumed allowable slip: $S:=\frac{1}{32}$. in $\quad$ Diameter of $16 \mathrm{~d}$ nail: $\quad D:=0.207$ in

Empirical constant: $k_{0} \quad 3200000 G$

Allowable load per nail in soft wood:

$$
\mathrm{k}_{0}^{\frac{3}{4}} \cdot\left(\frac{\mathrm{E}}{\mathrm{psi}}\right)^{\frac{1}{4}} \cdot\left(\frac{\mathrm{D}}{\mathrm{in}}\right)^{4} \cdot\left(\frac{\mathrm{S}}{\mathrm{in}}\right)^{7} \cdot \mathrm{bf} \quad \mathrm{p}=1105 \cdot \mathrm{lbf}
$$

Number of nails required: Nails $\quad$ ceil $\left(\frac{F_{c h}}{p}\right) \quad$ Nails $=12$

Cylindrical Packnge:

Assume a worst case cylindrical package with the following dimensions placed in a cradle fixed to conveyance bed:

Diameter: $d_{p}=8 . \mathrm{ft} \quad$ Length: $\quad I_{p}=40 \mathrm{ft}$ 
HNF-3341 Rev, O

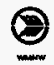

ENGINEERING SAFETY EVALUATION

Subject: DES Container Tiedown Requirements Evaluation

Preparer: S. S. Shiraga

Page 8 of 11

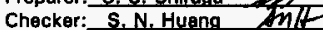

Date $09 / 08 / 98$

Section Chief: R.J. Smith $\& Z Z$

Date $09 / 10 / 98$

Weight is assumed as for a Cuboid package: $\quad$ Wpac $=50000^{\circ} \mathrm{lbf}$

In this case assume the center of gravity is conservatively at the geometric center for cylindrical packages.

CMTTA width of the cradle to contact with the cylinder is:

$$
w_{\text {cradle }}:=\frac{5}{8} \cdot d p \quad w_{\text {cradle }}=5 \cdot f t
$$

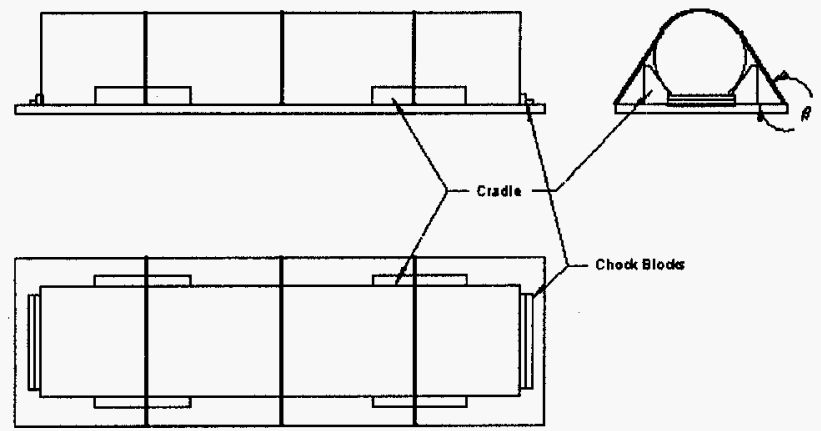

Based on this ratio: $\quad x_{\text {con }}: \frac{w_{\text {cradle }}}{2}$

and resulting angle of cradle: $\quad \alpha_{\text {con }}=$ asin $\left[\frac{x_{\text {con }}}{\left(\frac{d_{p}}{2}\right)}\right] \quad \alpha_{\text {con }}=39^{\circ} \mathrm{deg}$

WMINW.PE-001/2 
HNF-3341 Rev. 0

6

\section{ENGINEERING SAFETY EVALUATION}

Subject: DES Container Tiedown Requirements Evaluation Page 9 of 11

Preparer: S. S. Shiraga

Date $09 / 08 / 98$

Checker: S. N. Huang Ant

Date $09 / 10 / 98$

Section Chief: R.J. Smith $\mathcal{R}$

Date $09 / 10 / 98$

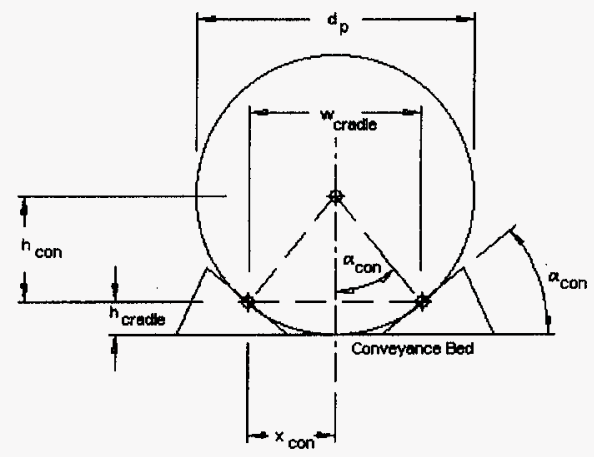

Distance from center of cylinder to contact point: $\quad h_{\operatorname{con}} \frac{x_{\operatorname{con}}}{\tan (\alpha \operatorname{con})} \quad h_{\operatorname{con}}=37.47 \cdot i$

Ratio of cylinder to cradle height to prevent rolling off: $\quad \mathbf{r}_{\mathbf{p r}} \frac{\mathbf{x}_{\text {con }}}{h_{\text {con }}} \quad \mathbf{r}_{\mathrm{pr}}=0.8$

Since: $\quad \mathbf{r}_{\mathbf{p r}}{ }^{>\mathbf{a}_{\mathrm{h}}} \quad$ cylinder will not roll over cradle under inertial load.

Minimum height of cradle: $h_{\text {cradle }}=\frac{d}{2} \cdot\left(1-\cos \left(\alpha_{\text {con }}\right)\right) \quad h_{\text {cradle }}=10.5$ 'in

Approximate ratio of contact width to height of cradle: $\frac{h_{\text {cradle }}}{w_{\text {cradle }}}=0.2$ 
HNF-3341 Rev. 0

9

ENGINEERING SAFETY EVALUATION

Subject:_DES Container Tiedown Reguirements Eyaluation

Preparer: S, S. Shiraga

Checker: S. N. Huang fath

Page 10 of 11

Date $\frac{09 / 08 / 98}{09}$

Section Chief: R.J. Smith $Z$

Date_09/10/98

Consequently height of cradle should be $1 / 5$ the contact width of the cradle.

Based upon above allowable compressive load, cradle lumber should be same as above.

Chains required to restrain vertical loading:

Working load limit of $1 / 2$ in alloy chains: $\quad w_{1 j m}:-13000 \mathrm{lbf}$

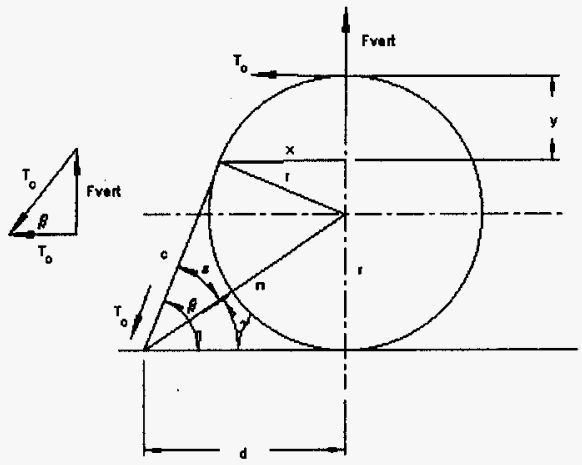

Radius of package: $r:=\frac{d \mathbf{p}}{2} \quad$ Distance to attachment: $d:=\frac{w t r}{2} \quad$ Angle: $\quad \gamma=\operatorname{atan}\left(\begin{array}{l}r \\ d\end{array}\right)$

Distance from attachment to center of package: $\quad n:-\sqrt{d^{2}+r^{2}}$

Length of attachment: $\quad c=\sqrt{n^{2}-r^{2}} \quad$ Angle off line $n: \varepsilon: \because \operatorname{acos}\left(\frac{c}{n}\right)$ 
HNF-3341 Rev. 0

\section{ENGINEERING SAFETY EVALUATION}

Subject: DES Container Tiedown Requirements Evaluation

Page 11 of 11

Preparer: S. S. Shiraga

Chocker: S.N. Huang AnUL

Date $09 / 08 / 98$

Section Chief: R.d. Smith

Date $09 / 10 / 98$

Angle off the deck: $\quad \beta==\gamma+\varepsilon \quad \beta=77 \cdot \mathrm{deg}$

Tension on chain: $\quad T_{c}=\frac{\text { Fvert }}{\sin (\beta)} \quad T_{c}=38438^{*}$ lbf

Number of $1 / 2$ in alloy chains required: $n_{\text {chain }}-\mathrm{ceil}_{(\mathrm{c}}\left(\begin{array}{c}\mathrm{T}_{\mathrm{c}} \\ \mathrm{w}_{\mathrm{lim}}\end{array}\right) \quad \mathrm{n}_{\text {chain }}=3$

End chocks:

Assume the height of vertical two $2 \mathrm{X} 4$ board assembled as an $L$ shape: $\quad h$ lum $\quad 3.5$-in

Area of a segment contacting the board:

$$
A_{\operatorname{seg}}\left(\frac{d_{p}}{2}\right)^{2} \cdot \operatorname{acos}\left|\frac{\frac{d_{p}}{2}-h_{\text {lum }}}{\left(\frac{d_{p}}{2}\right)}\right| \cdots\left(\frac{d_{p}}{2}-h_{\text {lum }}\right) \cdot \sqrt{2 \cdot \frac{d_{p}}{2} \cdot h_{1 u m}{ }^{-h}{ }_{l u m}^{2}}
$$

Worst case loading is longitudinal loading: $\quad F_{\text {ch }}-$ Flong $-\mu_{\text {mat }} \cdot W_{p a c} \quad F_{\text {ch }}=12500-l b f$

Compressive load on board: $\quad \frac{\mathrm{F}_{\text {ch }}}{\mathrm{A}_{\text {seg }}}=148 \cdot \mathrm{psi} \quad$ Therefore OK

Nailing chocks and cradles to conveyance deck same as for cuboid package. 


\section{DISTRIBUTION SHEET}

\begin{tabular}{|c|c|c|c|c|c|}
\hline \multirow{2}{*}{$\begin{array}{l}\text { To } \\
\text { Distribution }\end{array}$} & \multirow{2}{*}{\multicolumn{3}{|c|}{$\begin{array}{l}\text { From } \\
\text { Packaging Engineering }\end{array}$}} & \multicolumn{2}{|l|}{ Page 1 of 1} \\
\hline & & & & \multicolumn{2}{|c|}{ Date $09 / 30 / 98$} \\
\hline \multicolumn{4}{|l|}{ Project Title/Work Order } & \multicolumn{2}{|c|}{ EDT No. 622968} \\
\hline \multicolumn{4}{|c|}{$\begin{array}{l}\text { Safety Analysis Report for Packaging (Onsite) Decontaminated } \\
\text { Equipment Self-Container (HNF-3341) }\end{array}$} & \multicolumn{2}{|l|}{ ECN No. NA } \\
\hline Name & MSIN & $\begin{array}{l}\text { Text } \\
\text { With All } \\
\text { Attach. }\end{array}$ & Text Only & $\begin{array}{l}\text { Attach./ } \\
\text { Appendix } \\
\text { Only }\end{array}$ & $\begin{array}{l}\text { EDT/ECN } \\
\text { Only }\end{array}$ \\
\hline $\begin{array}{l}\text { D. W. Claussen } \\
\text { R. L. Clawson } \\
\text { J. G. Field } \\
\text { L. M. Hay } \\
\text { I. Henderson } \\
\text { J. H. Kelley } \\
\text { A. K. McDowe11 } \\
\text { M. A. McGhan } \\
\text { D. R. Pyzel } \\
\text { R. G. Robbins } \\
\text { M. R. Turner } \\
\text { Central Files } \\
\end{array}$ & $\begin{array}{c}\mathrm{S} 7-55 \\
\mathrm{H} 1-14 \\
\mathrm{H} 1-15 \\
\mathrm{HI}-15 \\
\mathrm{~T} 3-28 \\
\mathrm{~T} 4-15 \\
\mathrm{~T} 3-05 \\
\mathrm{HI}-15 \\
\mathrm{~S} 6-30 \\
\mathrm{~T} 3-28 \\
\mathrm{H} 1-15 \\
\mathrm{~B}-07 \\
\end{array}$ & $\begin{array}{l}x \\
x \\
x \\
x \\
x \\
x \\
x \\
x \\
x \\
x \\
x \\
x \\
\end{array}$ & & & \\
\hline $\begin{array}{l}\text { DOE/RL Reading Room } \\
\text { Hanford Technical Library }\end{array}$ & $\begin{array}{l}H 2-53 \\
\text { P8-55 }\end{array}$ & $\begin{array}{l}x \\
x\end{array}$ & & & \\
\hline
\end{tabular}

